Prepared in cooperation with the NORTH PLATTE NATURAL RESOURCES DISTRICT

\title{
Selected Field and Analytical Methods and Analytical Results in the Dutch Flats Area, Western Nebraska, 1995-99
}

\section{Open-File Report 00-413}

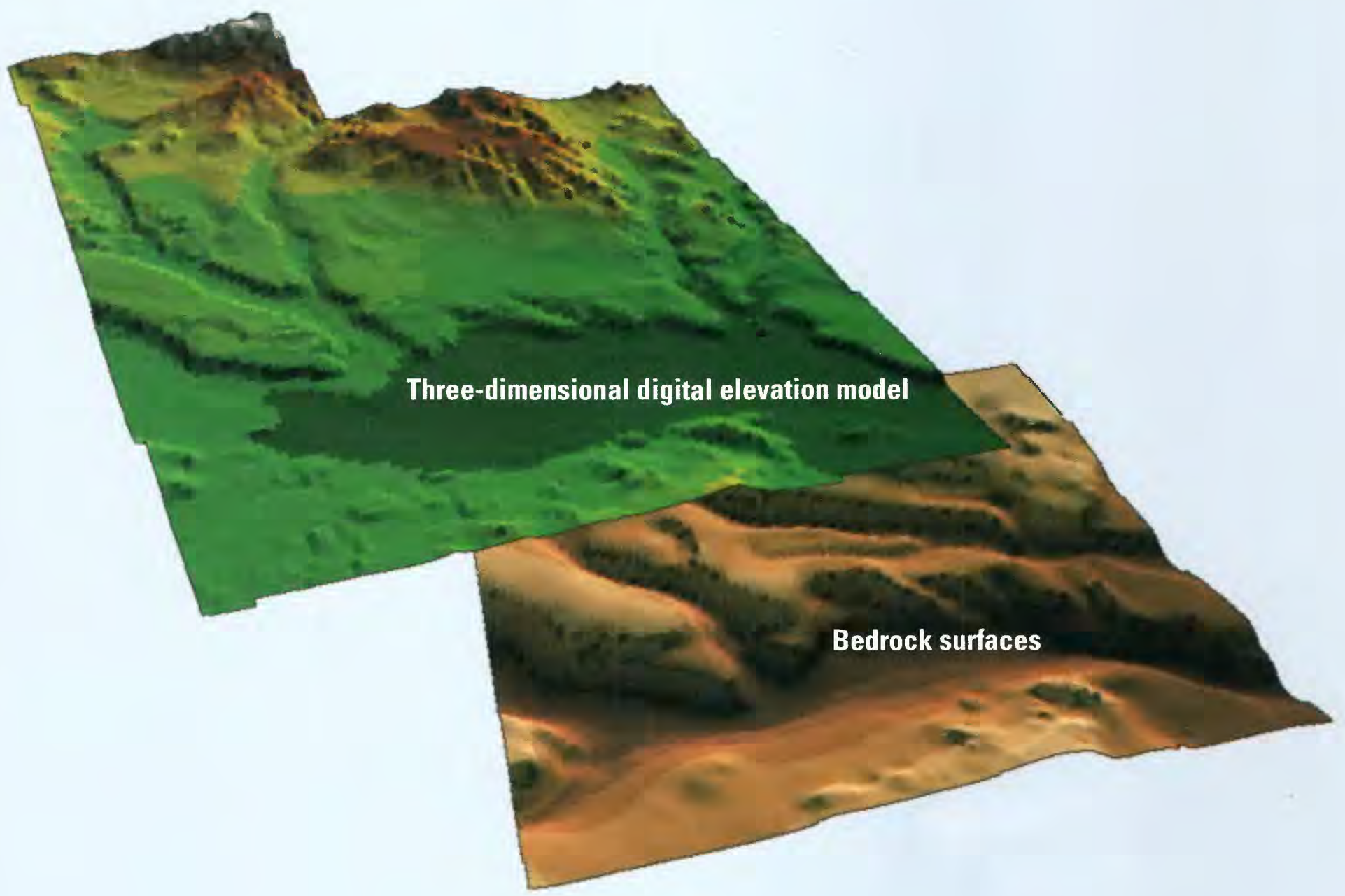





\section{Selected Field and Analytical Methods and Analytical Results in the Dutch Flats Area, Western Nebraska, 1995-99}

By I.M. Verstraeten, G.V. Steele, J.K. Böhlke, T.E. Kraemer, J.C. Cannia, D.E. Hitch, K.E. Wilson, and A.E. Carnes

Open-File Report 00-413 


\section{U.S. Department of the Interior \\ Gale A. Norton, Secretary}

\section{U.S. Geological Survey}

Charles G. Groat, Director

The use of firm, trade, and brand names in this report is for identification purposes only and does not constitute endorsement by the U.S. Geological Survey.

Lincoln, Nebraska: 2001

For additional information write to:

District Chief

U.S. Geological Survey

406 Federal Building

100 Centennial Mall North

Lincoln, NE 68508

Copies of this report can be purchased from:

U.S. Geological Survey

Information Services

Box 25286

Denver, CO 80225-0286 


\section{CONTENTS}

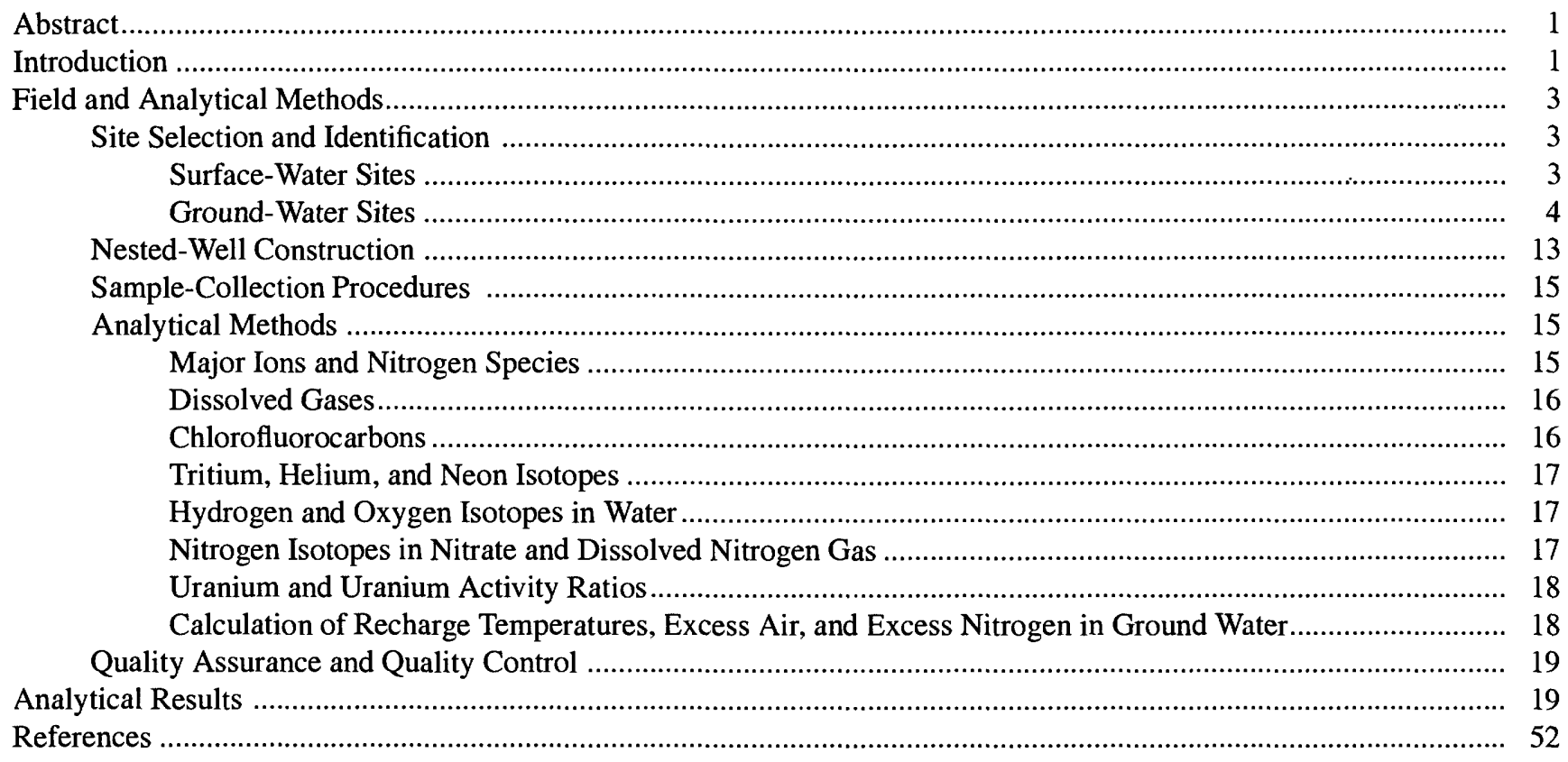

\section{FIGURES}

1. Map showing location of the Dutch Flats area and surface-water sampling sites, western Nebraska .................. 2

2. Map showing location of ground-water sampling sites, Dutch Flats area, western Nebraska ............................. 4

3. Diagram showing township-range-section numbering system ..................................................................... 14

\section{TABLES}

1. Surface-water sampling sites, Dutch Flats area, western Nebraska ...........................................................

2. Well information for ground-water-quality monitoring network, Dutch Flats area, western Nebraska .............. 5

3. Selected water-quality constituents, reporting levels, analytical methods, references for analytical methods, and regulatory levels used for the study, Dutch Flats area, western Nebraska,

4. Water temperature, dissolved oxygen, and dissolved-gas concentrations, and calculated recharge temperature, excess air, and excess nitrogen in surface- and ground-water samples from selected sites, Dutch Flats area, western Nebraska, 1998 through 1999

5. Nitrogen, hydrogen, oxygen, and helium isotopes in surface- and ground-water samples from selected sites, Dutch Flats area, western Nebraska, 1998 through 1999

6. Chlorofluorocarbons in surface- and ground-water samples from selected sites, Dutch Flats area, western Nebraska, 1998

7. Uranium concentrations and activity ratios in surface-water, ground-water, and well-cutting samples, Dutch Flats area, western Nebraska, 1995 through 1999 
CONVERSION FACTORS, ABBREVIATIONS, AND VERTICAL DATUM

\begin{tabular}{rcl}
\hline Multiply & By & To obtain \\
\hline inch (in.) & 2.54 & centimeter \\
inch (in.) & 25.4 & millimeter \\
foot (ft) & 0.3048 & meter \\
meter (m) & 3.281 & foot \\
mile (mi) & 1.609 & kilometer \\
& Weight & \\
gram (g) & 0.03527 & ounce \\
& Volume & \\
gallon (gal) & 3.785 & liter \\
liter (L) & 0.2642 & gallon \\
milliliter (mL) & 0.0338 & ounce, fluid \\
& Radioactivity & becquerels per liter \\
\hline
\end{tabular}

Temperature in degrees Celsius $\left({ }^{\circ} \mathrm{C}\right)$ may be converted to degrees Fahrenheit $\left({ }^{\circ} \mathrm{F}\right)$ as follows:

$$
{ }^{\circ} \mathrm{F}=\left(1.8 \times{ }^{\circ} \mathrm{C}\right)+32 .
$$

Temperature in degrees Fahrenheit $\left({ }^{\circ} \mathrm{F}\right)$ may be converted to degrees Celsius $\left({ }^{\circ} \mathrm{C}\right)$ as follows:

$$
{ }^{\circ} \mathrm{C}=\left({ }^{\circ} \mathrm{F}-32\right) / 1.8 \text {. }
$$

Sea level: In this report, "sea level" refers to the National Geodetic Vertical Datum of 1929 (NGVD of 1929) - a geodetic datum derived from a general adjustment of the first-order level nets of both the United States and Canada, formerly called Sea Level Datum of 1929.

Altitude, as used in this report, refers to distance above or below sea level.

Specific conductance is given in microsiemens per centimeter at 25 degrees Celsius $\left(\mathrm{mS} / \mathrm{cm}\right.$ at $\left.25^{\circ} \mathrm{C}\right)$.

Concentrations of chemical constituents in water are given either in milligrams per liter $(\mathrm{mg} / \mathrm{L})$, micrograms per liter ( $\mathrm{mg} / \mathrm{L})$, or picocuries per kilogram $(\mathrm{pg} / \mathrm{kg})$. 


\title{
Selected Field and Analytical Methods and Analytical Results in the Dutch Flats Area, Western Nebraska, 1995-99
}

\author{
By I.M. VERSTRAETEN ${ }^{1}$, G.V. STEELE ${ }^{1}$, J.C. CANNIA ${ }^{2}$, J.K. BÖHLKE ${ }^{3}$, T.E. KRAEMER ${ }^{3}$ \\ D.E. HITCH ${ }^{4}$, K.E. WILSON ${ }^{1}$, and A.E. CARNES ${ }^{1}$
}

\section{Abstract}

A study of the water resources of the Dutch Flats area in the western part of the North Platte Natural Resources District, western Nebraska, was conducted from 1995 through 1999 to describe the surface water and hydrogeology, the spatial distribution of selected water-quality constituents in surface and ground water, and the surface-water/ground-water interaction in selected areas. This report describes the selected field and analytical methods used in the study and selected analytical results from the study not previously published. Specifically, dissolved gases, age-dating data, and other isotopes collected as part of an intensive sampling effort in August and November 1998 and all uranium and uranium isotope data collected through the course of this study are included in the report.

\section{INTRODUCTION}

Human activities, such as agriculture, commonly affect the distribution, interaction, and quality of surface and ground water. It has been demonstrated that contaminated aquifers discharging to streams can degrade surface-water quality and that streams discharging to ground water can degrade ground-water

\footnotetext{
${ }^{1}$ U.S. Geological Survey, Lincoln, Nebraska.

${ }^{2}$ North Platte Natural Resources District, Gering, Nebraska.

${ }^{3}$ U.S. Geological Survey, Reston, Virginia.

${ }^{4}$ U.S. Geological Survey, North Platte, Nebraska.
}

quality, especially when induced infiltration occurs (Verstraeten and others, 1999). A study of the water resources of the Dutch Flats area in the western part of the North Platte Natural Resources District (NRD), western Nebraska, was conducted from 1995 through 1999 to describe the surface water and hydrogeology, the spatial distribution of selected water-quality constituents in surface and ground water, and the surface-water/ground-water interaction in selected areas.

The Dutch Flats area, a part of Scotts Bluff and Sioux Counties, in the western part of the North Platte NRD (fig. 1), encompasses the majority of the study area and locally is the prominent terrain feature. It also includes an area north of the Interstate Canal and south of the Platte River. Previous studies (Conservation and Survey Division, 1980a, b; Verstraeten and others, 1995; Steele and Cannia, 1997; Druliner and others, 1999) suggested that large amounts of nitrate are present in ground water from the alluvial sediment in the Dutch Flats area but are not present in surface water. These studies also suggested that at selected locations in the Dutch Flats area, large concentrations of radon, uranium, and gross alpha as natural uranium are present. Concentrations in excess of existing or proposed U.S. Environmental Protection Agency (2000) Maximum Contaminant Levels (MCLs) for nitrate, radon, and uranium were found in surface or ground water.

To evaluate the water resources in the Dutch Flats area, more information was needed about the quantity and quality of surface and ground water and their interactions. To evaluate the interaction of surface and ground water, a study was conducted from 1995 through 1999 by the U.S. Geological Survey (USGS), 


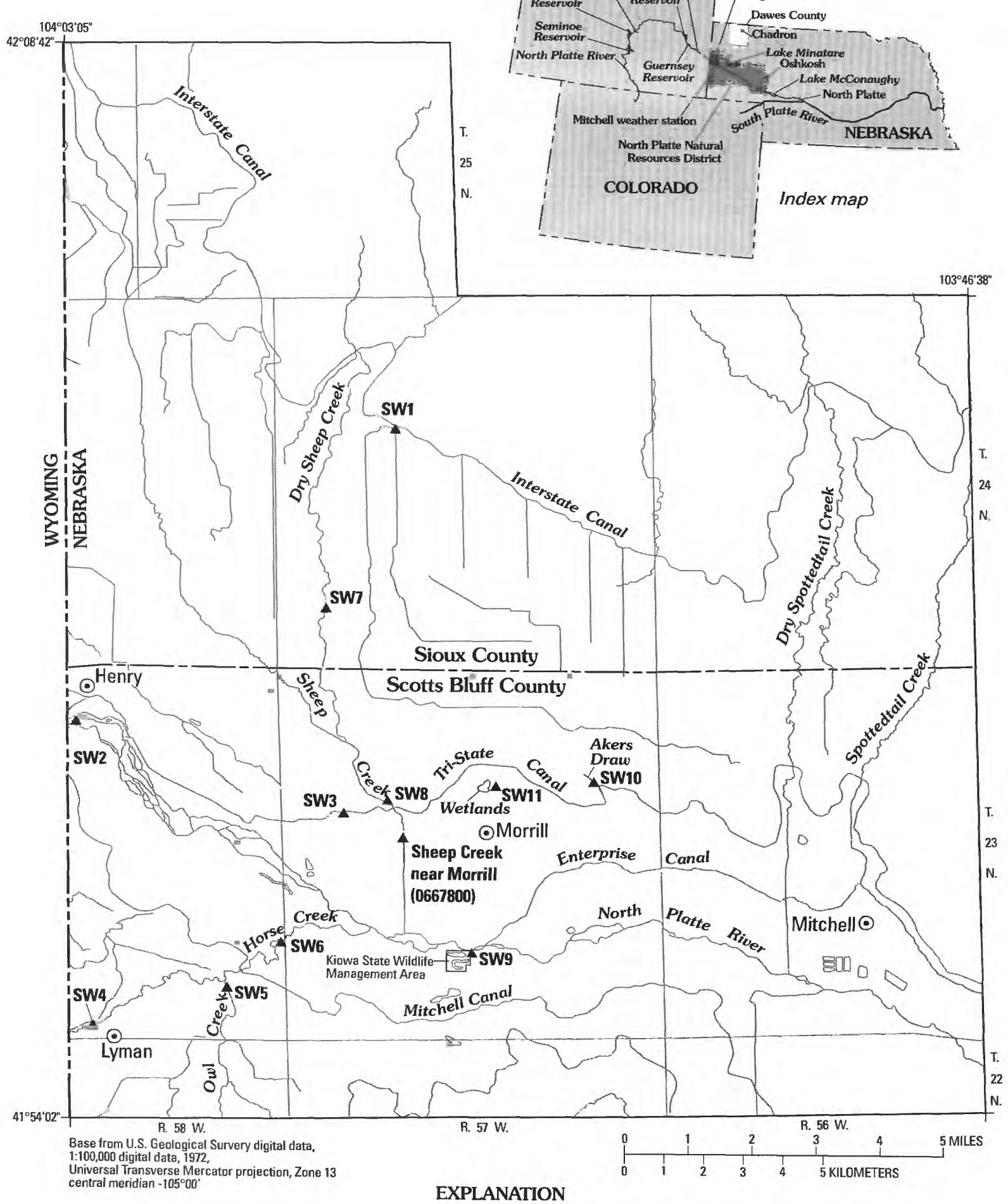

SW5 $_{A}$ Surface-water sampling site (table 1) and map index number

Figure 1. Location of the Dutch Flats area and surface-water sampling sites, western Nebraska. 
in cooperation with the North Platte NRD, to define the surface-water/ground-water interaction and the potential effect of seepage from irrigation canals on water quantity and quality in the Dutch Flats area (fig. 1) in the western part of the North Platte NRD. The specific objectives of the study were:

- To describe surface water and hydrogeology,

- To describe spatial distribution of selected waterquality constituents in surface and ground water,

- To describe surface-water/ground-water interaction in selected areas, and

- To estimate ground-water, nitrogen, and uranium fluxes.

The purpose of this report is to describe the selected field and analytical methods used in the study and the analytical results of the study not published in the USGS Water-Data Reports for 1997, 1998, and 2000 (Boohar and Walczyk, 1997, p. 254-273, 1998, p. 303-395; Boohar, 2000, p. 342-417). The previously published analytical results can be retrieved from the USGS National Water Information system on the World Wide Web at URL:

http://water.usgs.gov/ne/nwis/nwis

\section{FIELD AND ANALYTICAL METHODS}

Surface-water and ground-water site selection and identification are described in this report, in addition to ground-water monitoring-well construction methods. The sample collection and laboratory procedures also are described, as well as the qualityassurance and quality-control measures used during the study. Most of the geologic nomenclature used in this report is that used by the USGS. However, the term "Lance aquifer" is used by the University of Nebraska-Lincoln Conservation and Survey Division.

\section{Site Selection and Identification}

\section{Surface-Water Sites}

Eleven surface-water sites representing the major hydrologic features in the Dutch Flats area were selected for this study (fig. 1, table 1). One spring, Akers Draw, also was included to evaluate groundwater seepage from the upland terrace. Water in the Interstate Canal is withdrawn from the North Platte River about 50 mi upstream in Wyoming. Site accessibility was a major consideration in the siteselection process.

For identification of surface-water sampling sites, the first identifier is the USGS official station name (table 1). The second identifier, generally an eight-

Table 1. Surface-water sampling sites, Dutch Flats area, western Nebraska

[USGS, U.S. Geological Survey; ft, feet]

\begin{tabular}{|c|c|c|c|c|}
\hline $\begin{array}{c}\text { Map } \\
\text { index } \\
\text { number } \\
\text { (fig. 1) }\end{array}$ & USGS site name & $\begin{array}{l}\text { USGS identification } \\
\text { number }\end{array}$ & $\begin{array}{l}\text { Latitude and } \\
\text { longitude } \\
\text { (degrees, minutes, } \\
\text { seconds) }\end{array}$ & $\begin{array}{c}\text { Land- } \\
\text { surface } \\
\text { altitude } \\
\text { (ft above } \\
\text { sea level) }\end{array}$ \\
\hline SW1 & Interstate Canal 6 miles northwest of Morrill, Nebr. & 06656630 & 4203261035706 & 4,206 \\
\hline SW2 & North Platte River at Wyoming-Nebraska State line & 06674500 & 4159251040257 & 4,020 \\
\hline SW3 & Tri-State Canal 2 miles west of Morrill, Nebr. & 06675100 & 4158081035804 & 4,013 \\
\hline SW4 & $\begin{array}{l}\text { Horse Creek } 0.5 \text { mile downstream from } \\
\text { Wyoming-Nebraska State line }\end{array}$ & 06677120 & 4155121040240 & 4,040 \\
\hline SW5 & Owl Creek near Lyman, Nebr. ${ }^{1}$ & 06677300 & 4155481040017 & 4,020 \\
\hline SW6 & Horse Creek near Lyman, Nebr. & 06677500 & 4156211035913 & 3,992 \\
\hline SW7 & Dry Sheep Creek near Morrill, Nebr. & 06677985 & 4200581035823 & 4,060 \\
\hline SW8 & $\begin{array}{l}\text { Sheep Creek north of Tri-State Canal, } \\
\text { near Morrill, Nebr. }\end{array}$ & 06677995 & 4158141035714 & 4,008 \\
\hline SW9 & North Platte River at Morrill, Nebr. & 06678500 & 4156121035544 & 3,978 \\
\hline SW10 & Akers Draw near Morrill, Nebr. & 06678610 & 4158331035329 & 4,010 \\
\hline SW11 & Wetlands 0.75 mile north of Morrill, Nebr. & 415830103551701 & 4158301035517 & 3,980 \\
\hline
\end{tabular}

${ }^{1}$ This station is on that part of the stream previously called Kiowa Creek by the USGS. 
digit surface-water USGS identification number, is assigned in a downstream direction along the main stream. The first two digits " 06 " represent the major river basin, which is the Missouri River Basin. However, because the wetlands site is not a flowing stream, the wetlands site (SW11) was identified in a fashion similar to a ground-water site as described later in this section.

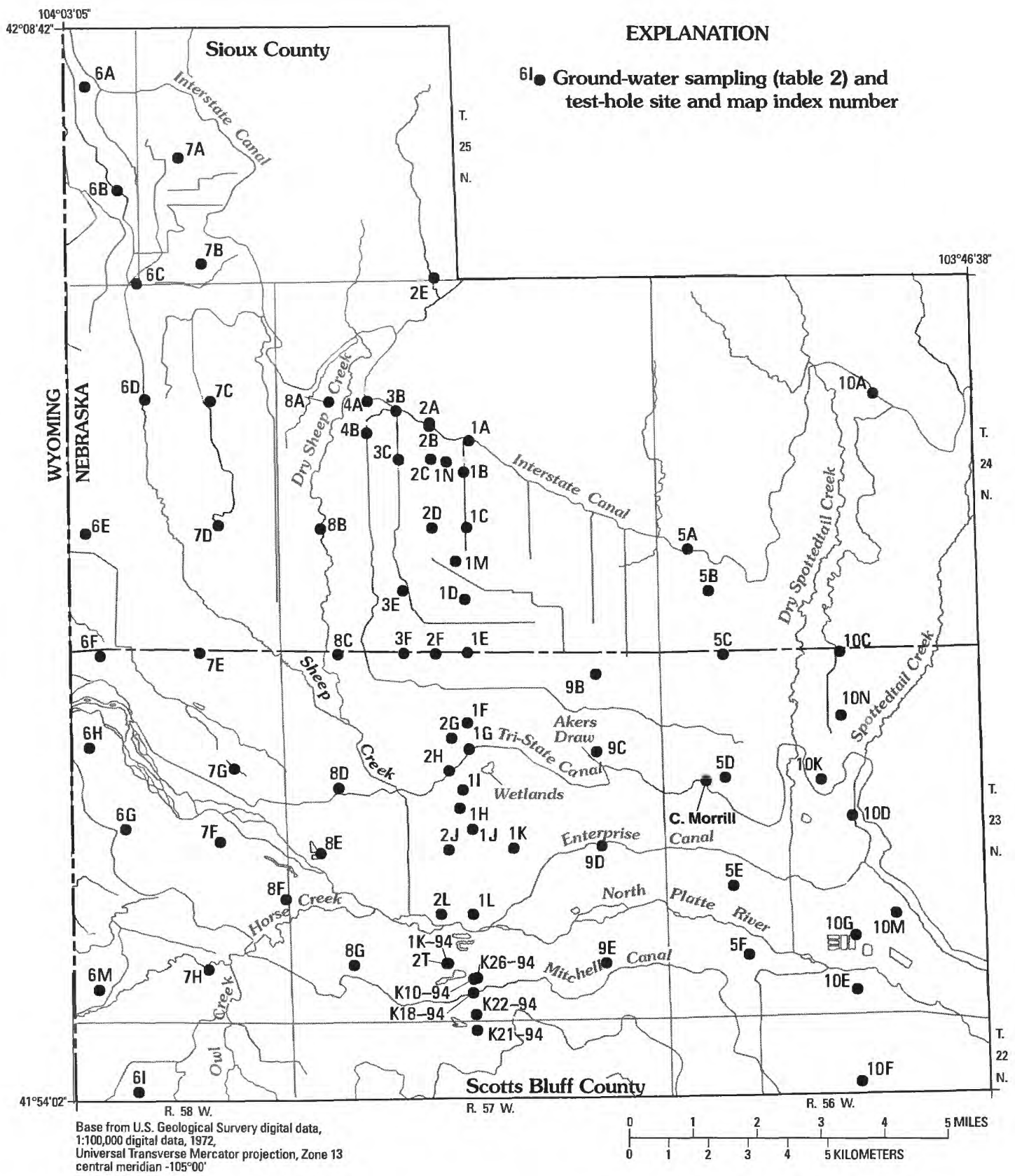

Figure 2. Location of ground-water sampling sites, Dutch Flats area, western Nebraska. 


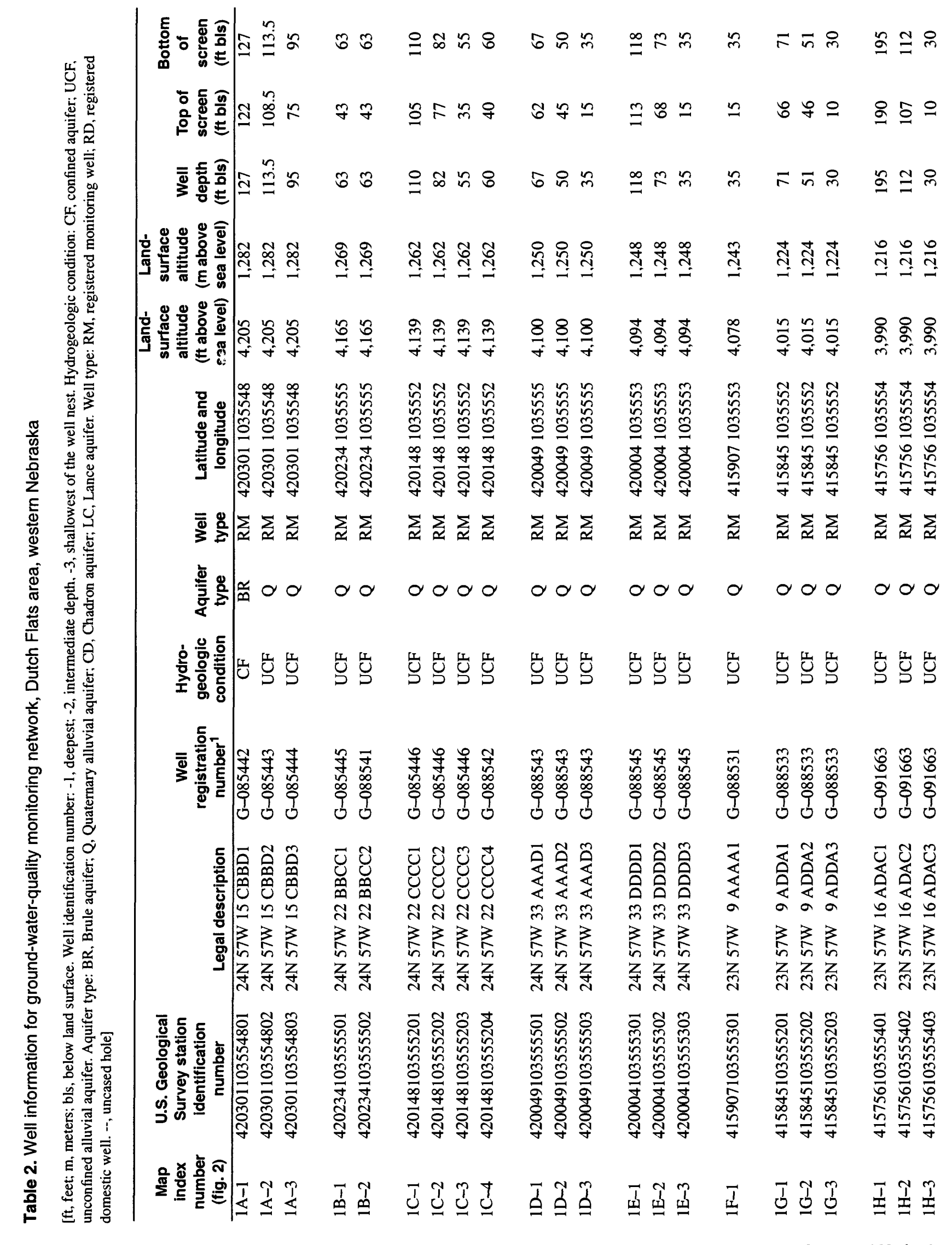




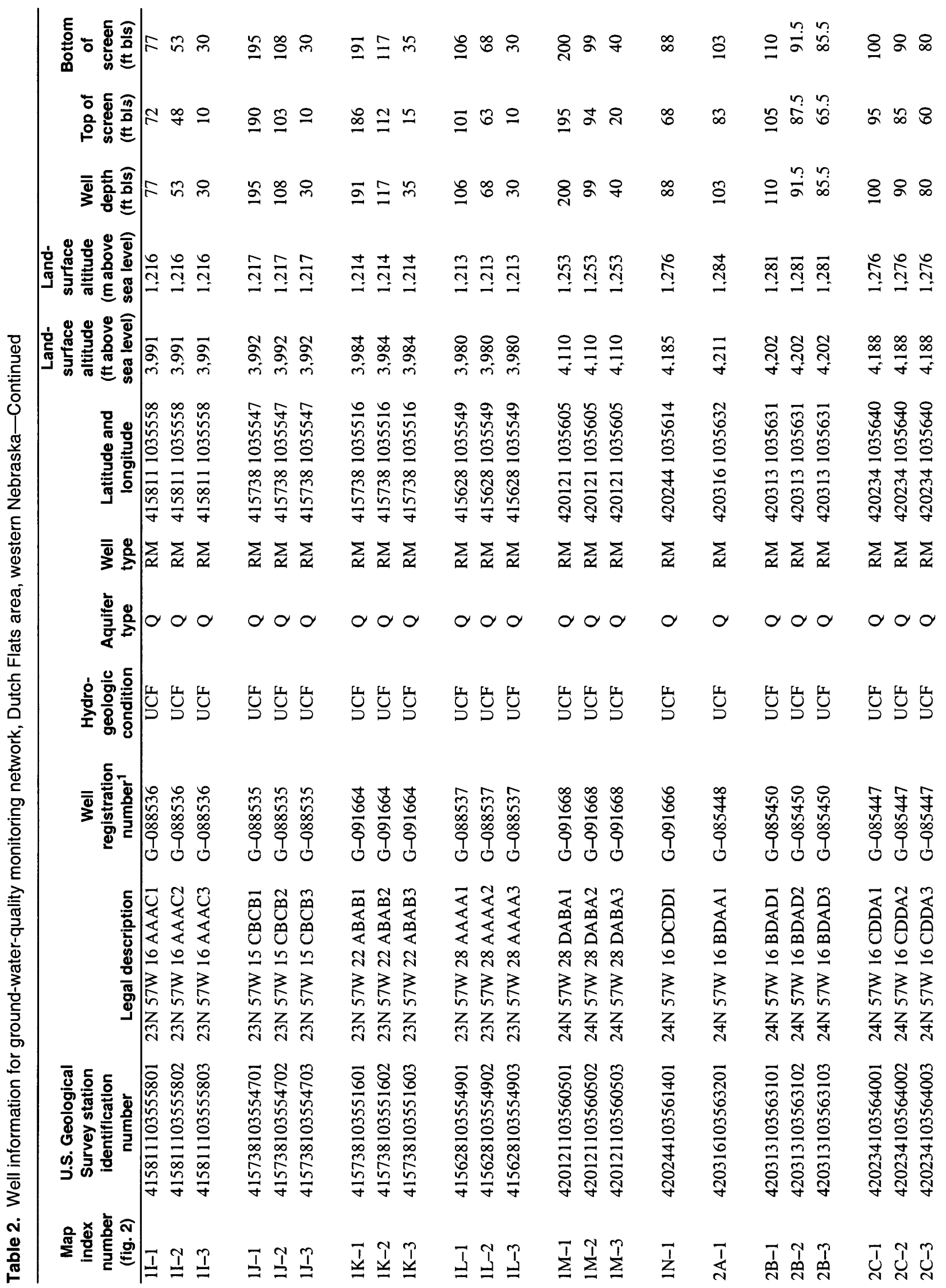




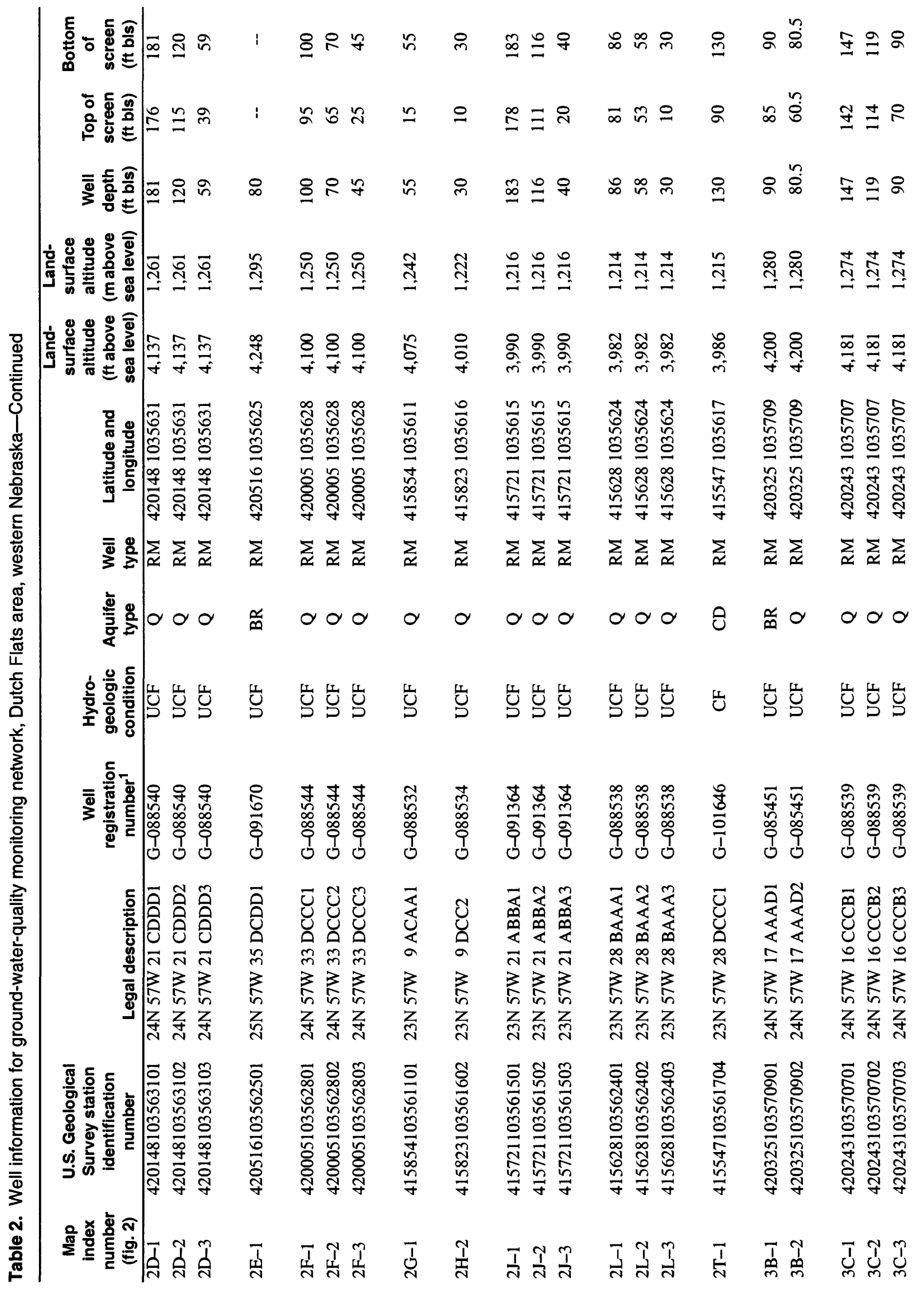




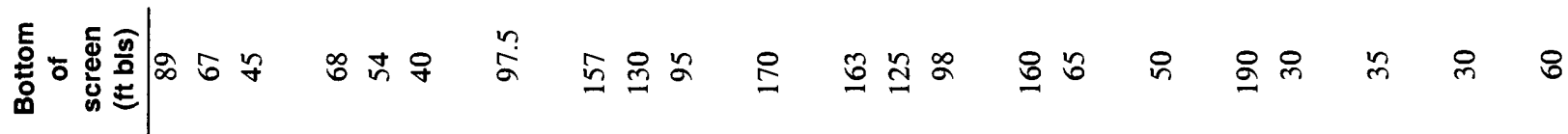

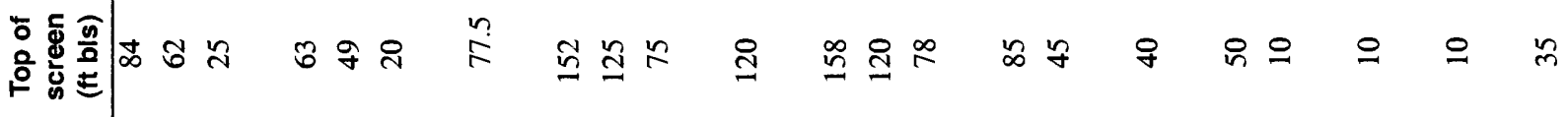

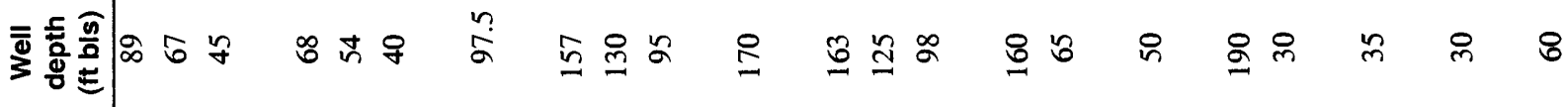

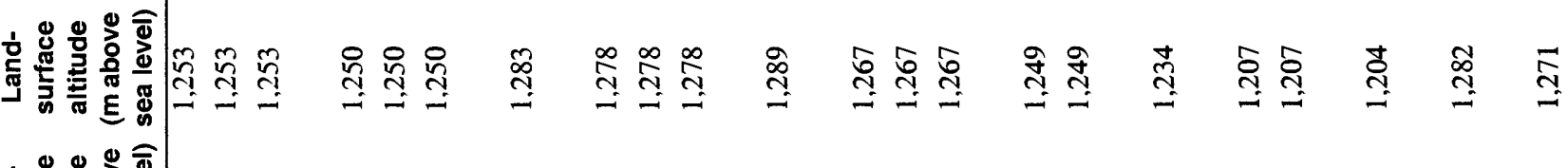

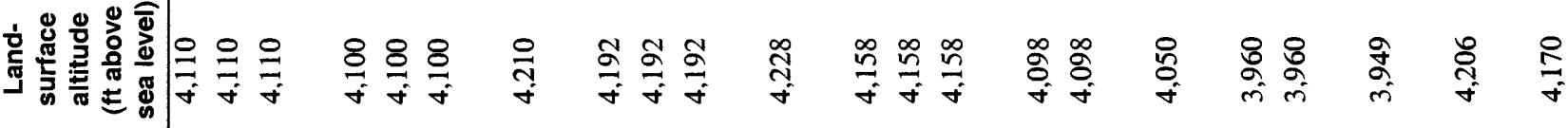

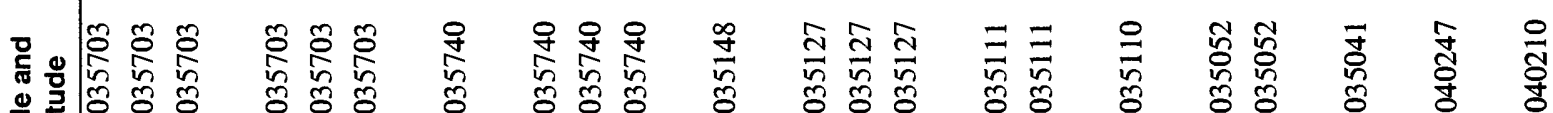

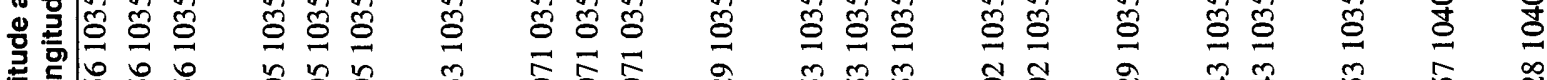

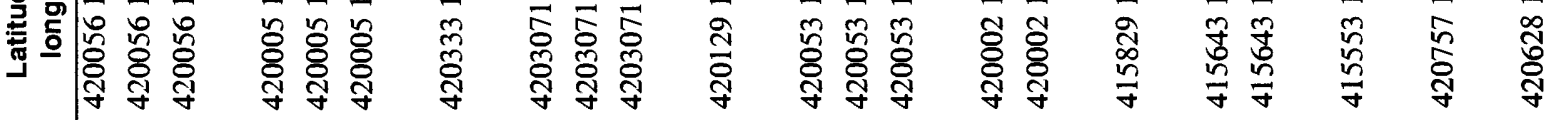

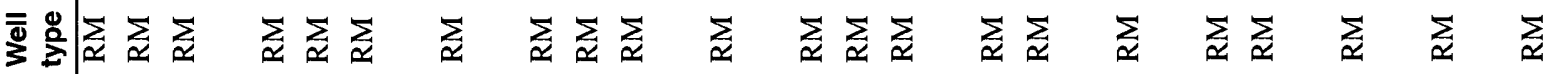
产哭

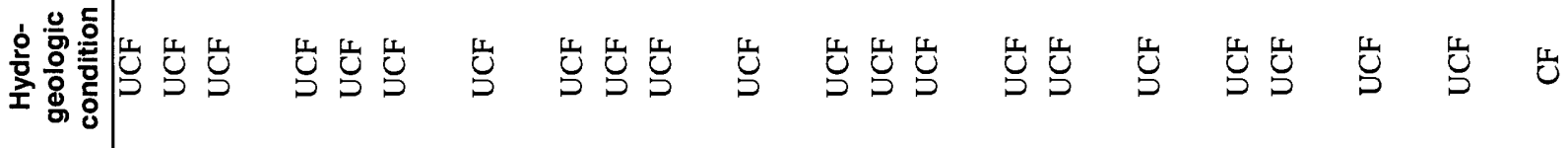

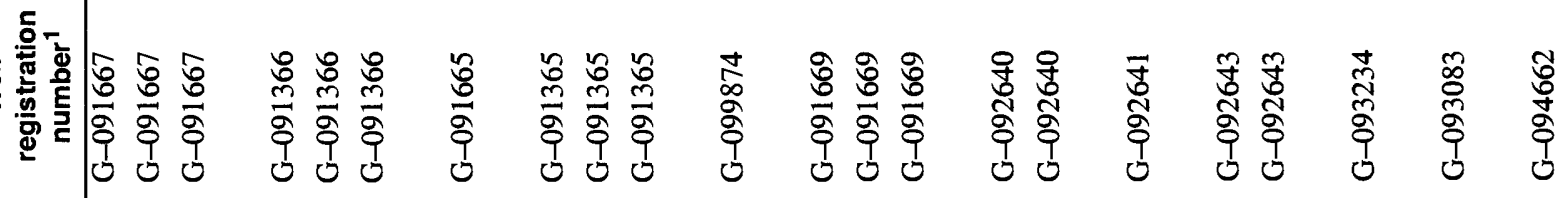

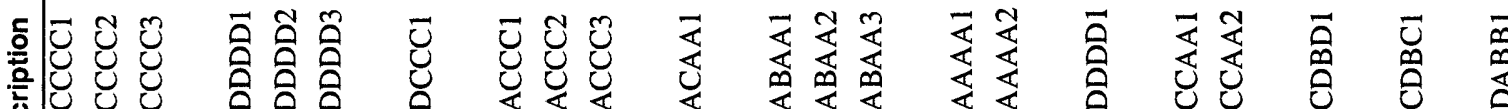

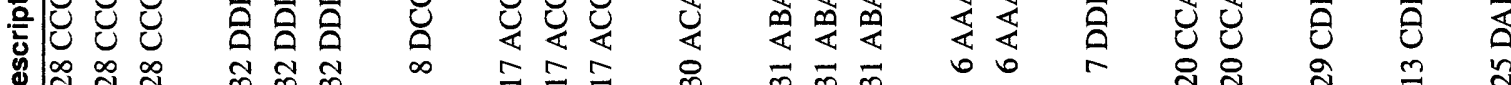

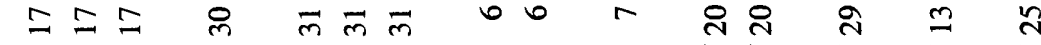

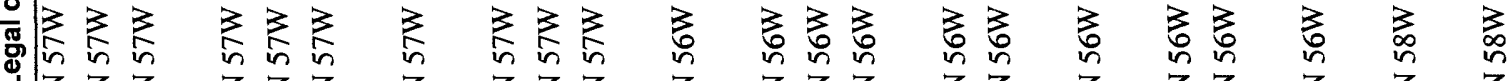

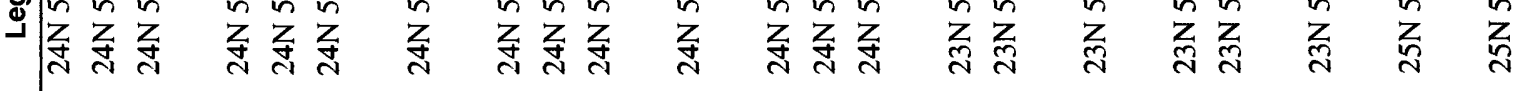




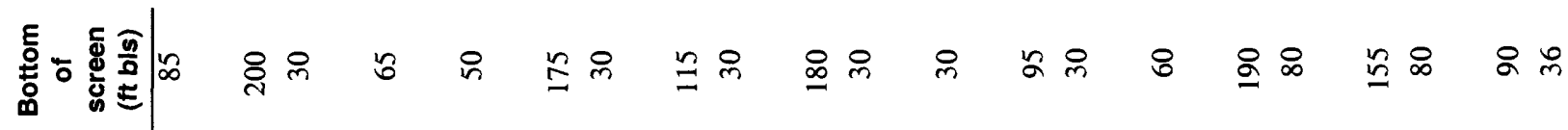

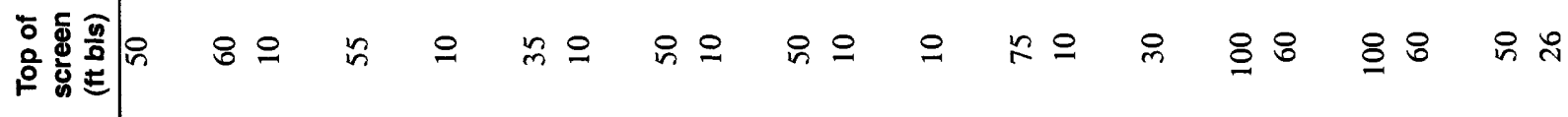

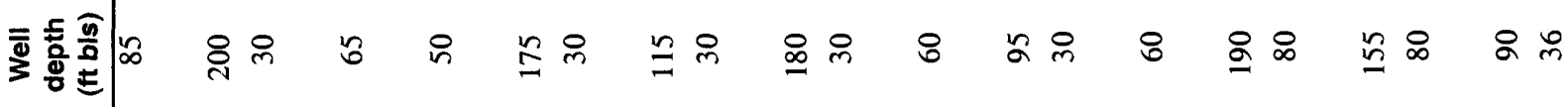

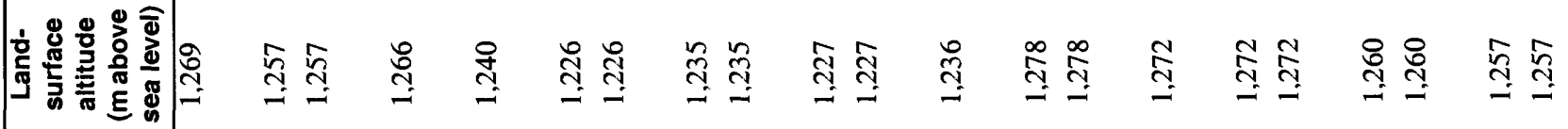

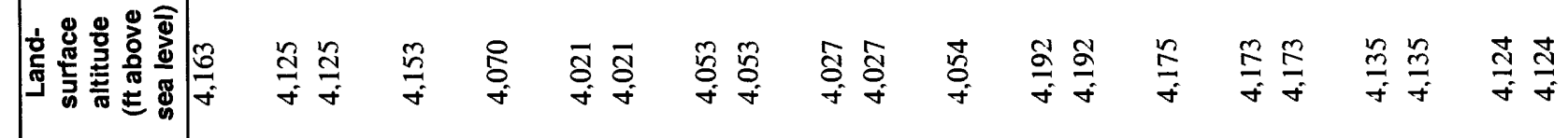

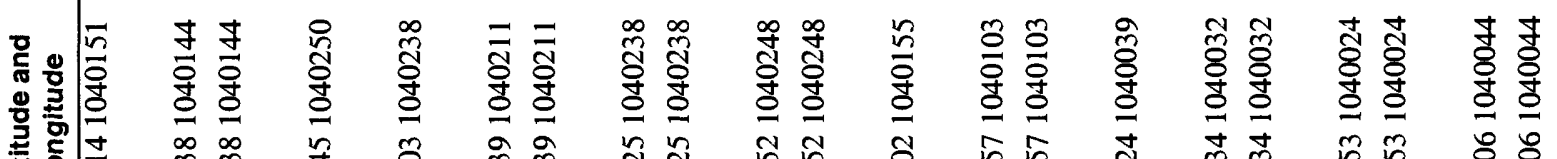

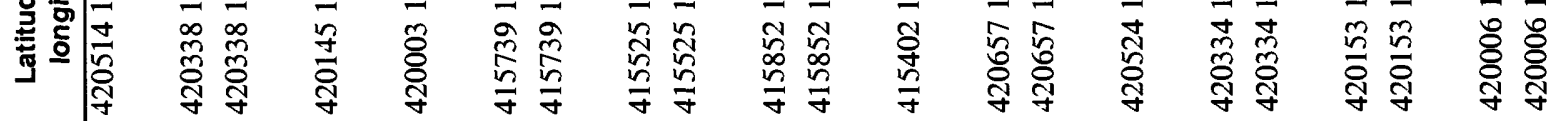

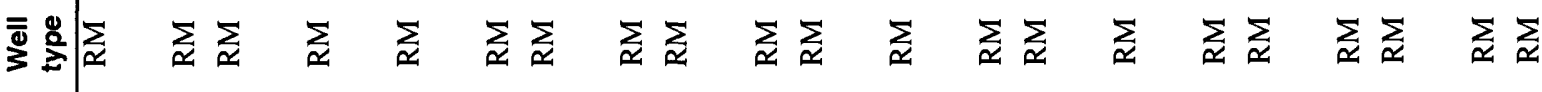

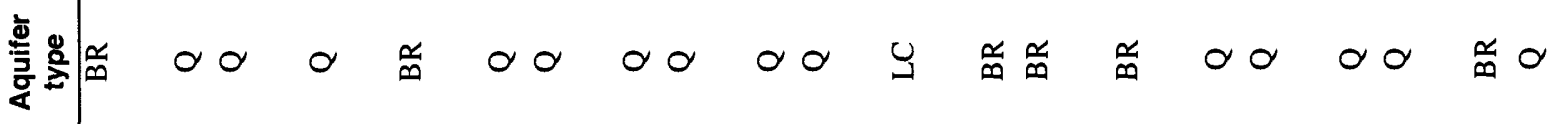

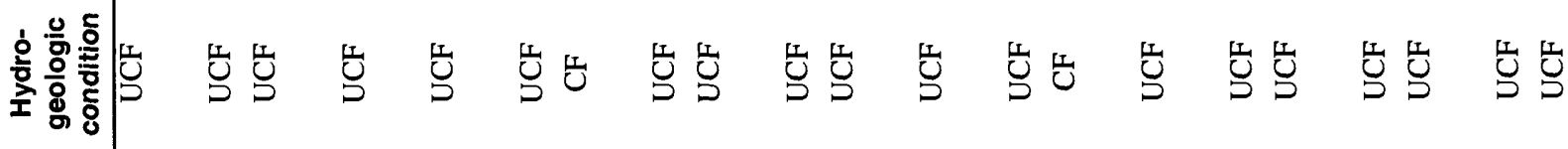

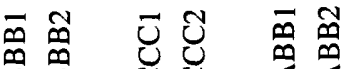
<造 


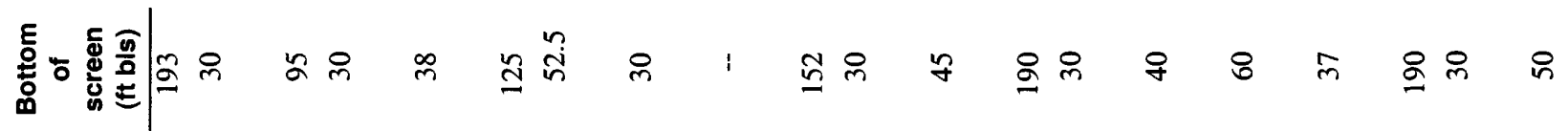

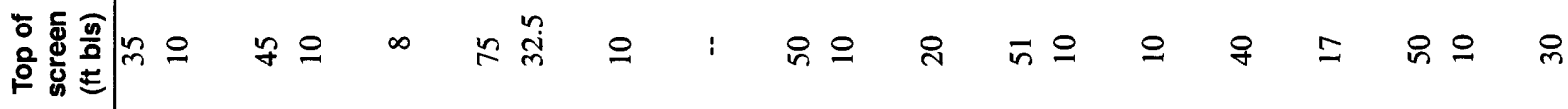

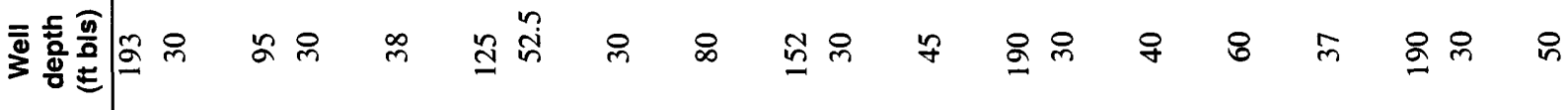

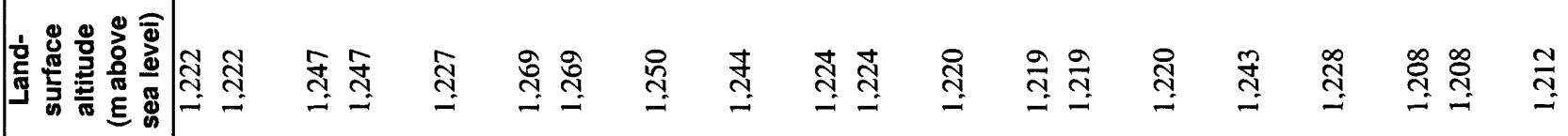

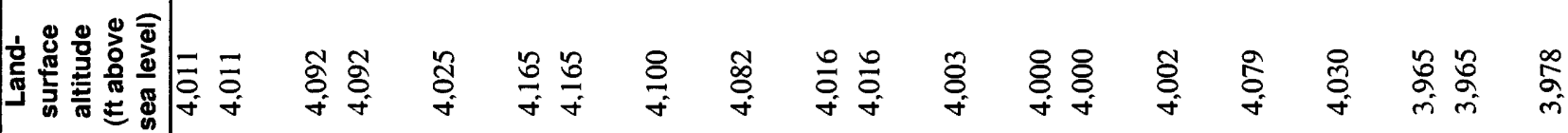

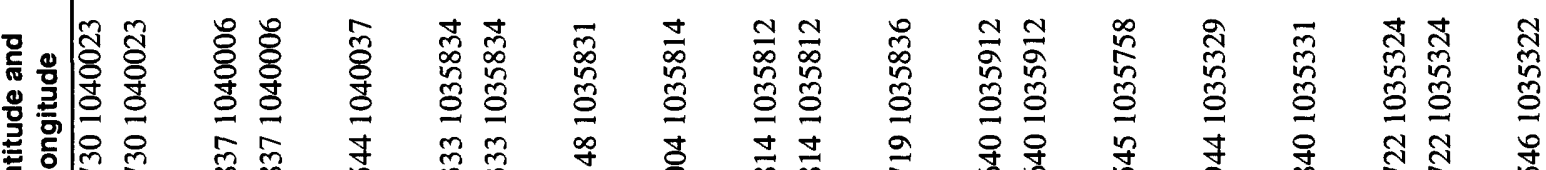

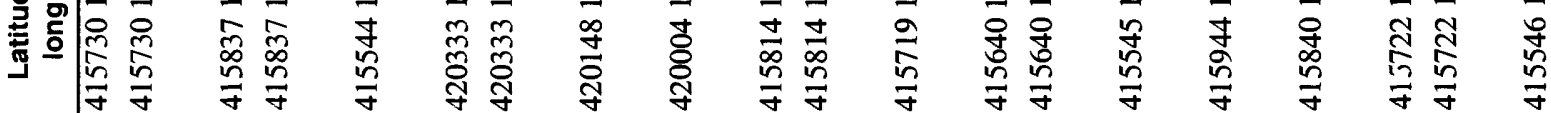

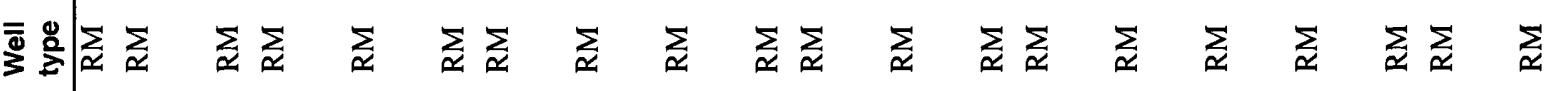

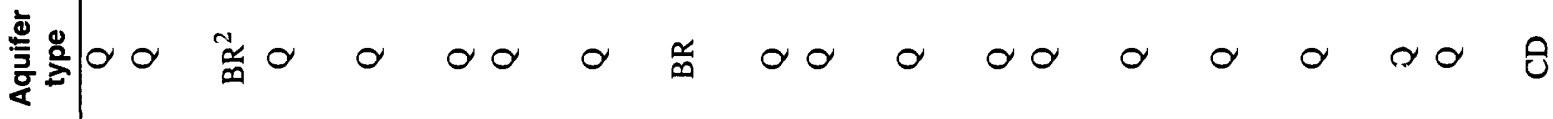

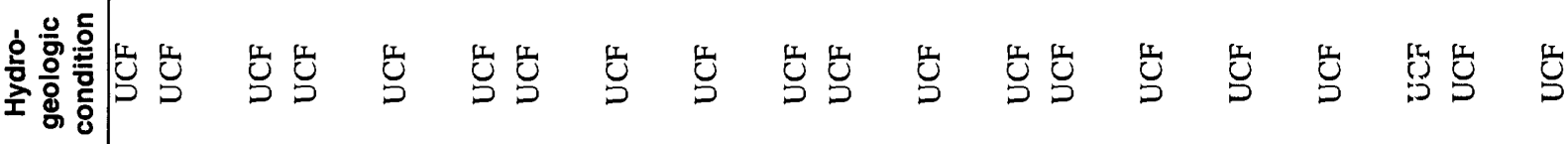




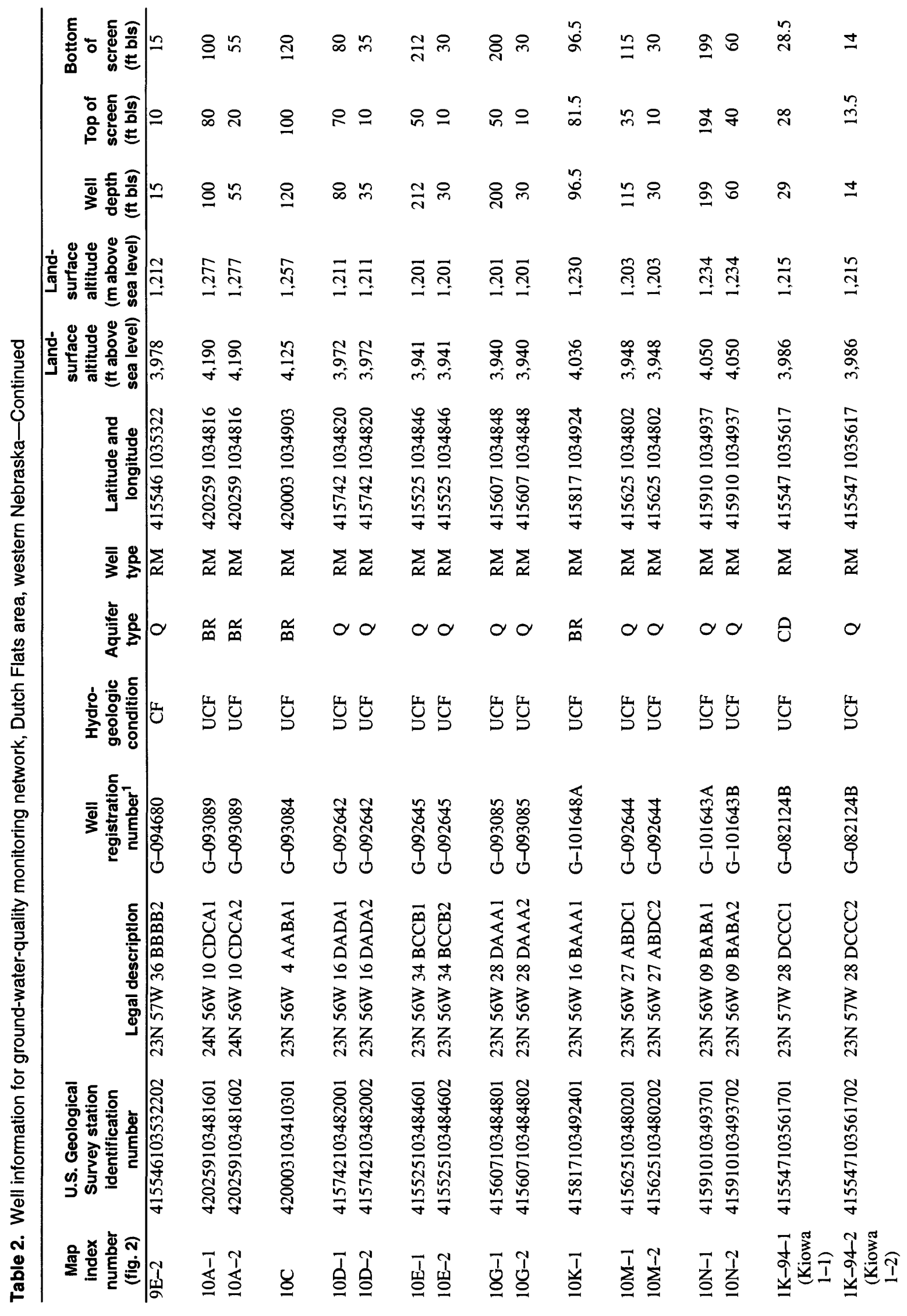




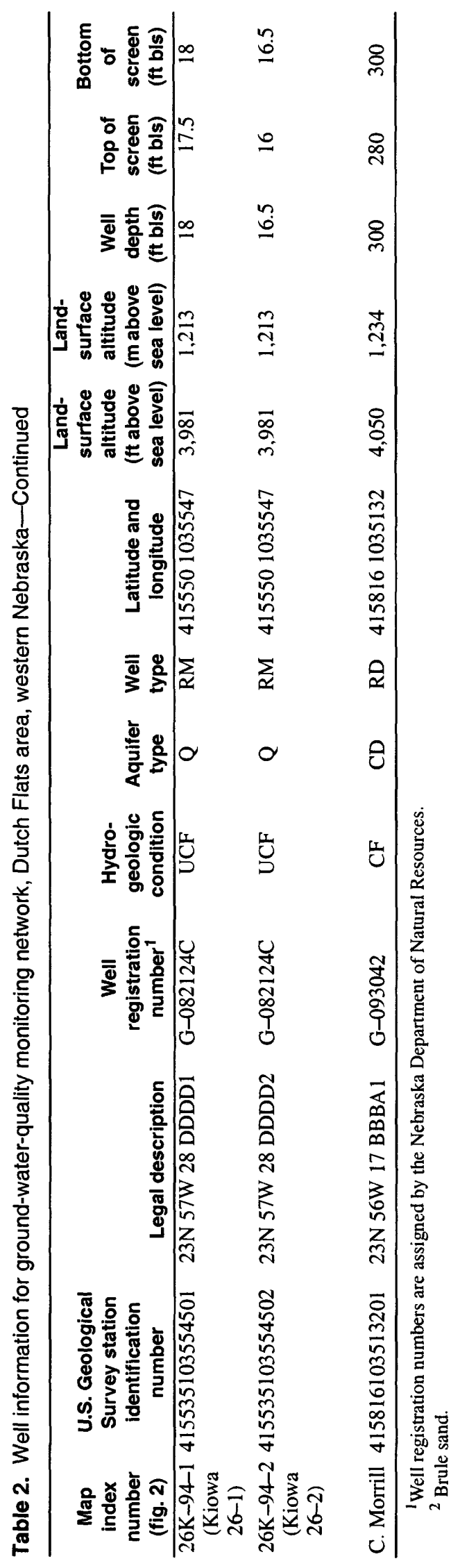

12 Selected Field and Analytical Methods and Analytical Results in the Dutch Flats Area, Western Nebraska, 1995--99 
Initially three transects were installed in a northsouth direction near the center of the study area. Sets of nested wells in a transect are about $1 \mathrm{mi}$ apart. Two sites (2A and $2 \mathrm{E}$ ) are upgradient of the Interstate Canal; all other sites are in or near areas with active surface-water irrigation and are downgradient from the Interstate Canal. Additional nested wells were installed at approximately 2-mi intervals in the study area.

Analysis of the chemical interaction between surface and ground water requires transects that are parallel to ground-water flow paths, hereinafter referred to as flow paths. Flow paths in the study area are variable. To determine vertical ground-water flow components, nested wells with screens completed at different depths were installed at locations having sufficient saturated thickness. Sufficient saturated thickness was determined by drilling a test hole. Sufficient saturated thickness was defined as areas containing saturated sand and gravel deposits of about $20 \mathrm{ft}$ (feet) or more. In areas containing saturated deposits less than $20 \mathrm{ft}$ thick, a single well was installed.

Four different methods of ground-water site identification were used in this report (table 2). The first method, well identification number/station name, is associated with the transect number for the wells. Each well in a transect was given a 3- or 4-character identification-number, letter, number format. The first number assigned was based on the transect number in which the well was located-first transect (1), second transect (2), and so forth. The letter sequence designated wells farthest north as $\mathrm{A}$, then southward to $\mathrm{B}, \mathrm{C}$, and so forth, with some exceptions. Terminal numbers were assigned to monitoring wells in a nest and were based on relative well depthdeepest, -1 ; medium or intermediate depth, -2 (or shallowest for a two-well nest); and shallowest, -3 (for a three-well nest). Locations containing a single monitoring well were assigned a single terminal number (such as $1 \mathrm{~F}-1$ ) or no terminal number (such as $5 \mathrm{D}$ ).

The second method is the unique USGS station identification number, which is a 15-character number derived from the international system of latitude and longitude. This number contains no blanks or alphabetic characters and generally is used as a control number. Although the station identification number was derived initially from the site location, the number is a numeric identifier and has no locational significance (Mathey, 1990, p. 2-10). If two or more wells are located within the same second of latitude or longi- tude, they are distinguished by adding a sequential digit to the number. Sequential numbers are assigned by order of inventory.

The third method, the legal description (fig. 3, table 2), is based on the land subdivisions from the U.S. Bureau of Land Management's survey of Nebraska. The number preceding $N$ (north) indicates the township or tier, the number preceding W (west) indicates the range, and the number preceding the terminal letters indicates the section in which the well is located. The last letters, designated A, B, C, and D, denote the quarter section, the quarter-quarter section, the quarter-quarter-quarter section, and the quarterquarter-quarter-quarter section. The designation is given in a counterclockwise direction beginning with " $\mathrm{A}$ " in the northeast corner of each subdivision. Like the USGS station identification number, if two or more wells are located within the same subdivision, they are distinguished by adding a sequential digit to the well number and are assigned by order of inventory. For example, 24N 57W 15 CBBD1 (fig. 3) would be in township 24 north, range 57 west, section 15 , quarter section $\mathrm{C}$, quarter-quarter section $\mathrm{B}$, quarter-quarterquarter section $\mathrm{B}$, and quarter-quarter-quarter-quarter section $D$, inventory sequence 1 . The fourth method is the well registration number (G-085442), which is assigned by the Nebraska Department of Natural Resources.

\section{Nested-Well Construction}

Sixty-nine nested wells were installed for this study between 1995 and 1999 (fig. 2). All nested wells consisted of one to three wells. Each well was constructed of 2.5-in., schedule- 40 polyvinyl chloride (PVC) pipe with 0.010 -in. slotted PVC well screen. All monitoring wells were installed using direct rotary methods and, in most instances, the deepest well of the nest was completed near or in the bedrock. Occasionally, because of the large size (typically cobbles) or the great thickness of the unconsolidated sediment, the test-hole drillers were unable to reach bedrock. In these instances, the deepest well was assumed to be near bedrock. Two wells (fig. 2, wells $2 \mathrm{E}-1$ and $8 \mathrm{C}$ ) are completed in the Brule Formation as uncased holes. Lithologic and driller's construction logs, and at some sites, electric logs, were collected at each site. Because bentonite was used to seal each well and bentonite can contain radon and uranium (two of the constituents in the water-quality samples), a test well 
Well number

24N 57W 15 CBBD1

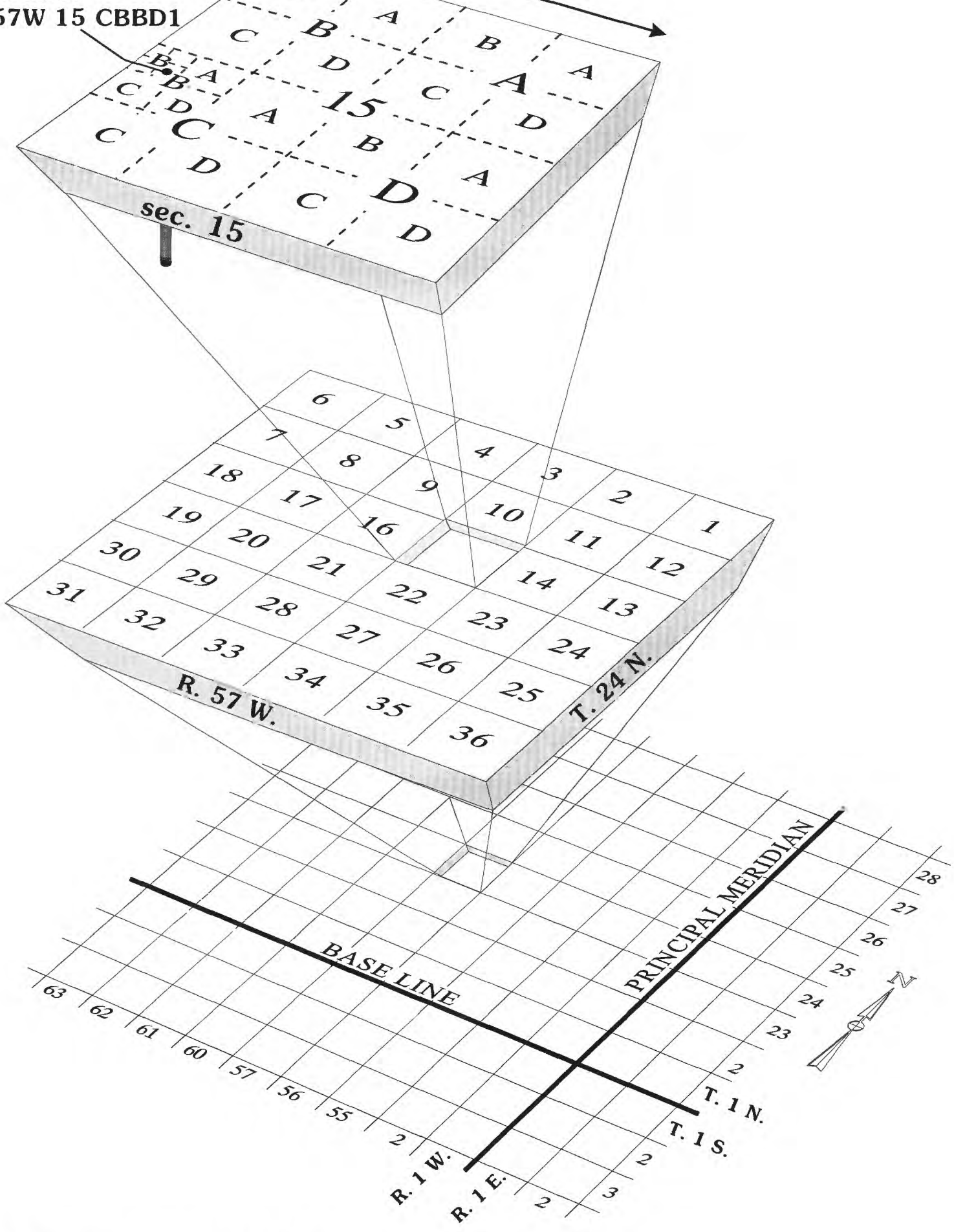

Figure 3. Township-range-section numbering system. 
(1B-2) was installed near a typical monitoring-well site (1B-1) to confirm that radon and uranium detections in ground-water samples were from the water and not from the bentonite. The test well was installed using direct-mud-rotary methods without a bentonite seal.

\section{Sample-Collection Procedures}

Samples were collected following USGS guidelines to ensure the collection of representative samples. On the basis of wells constructed, the flow of water through the canals, and the information collected the previous years, a yearly sampling scheme was developed. The sampling schemes included the constituents for which samples would be analyzed, a list of the collection sites, and frequency and timing of collection.

Surface-water samples were collected using equalwidth increment (EWI) sampling procedures or centroid-of-flow (COF) sampling procedures as described by Wells and others (1990). However, at the wetlands site near Morrill (site SW11, fig. 1), a dip sample was collected. COF samples were collected from both irrigation canal sites (SW1 and SW3, fig. 1). Water in these canals is considered well mixed (Steele and Cannia, 1997). EWI sampling was used at the remainder of the sites where the streamflow was not considered well mixed. All water-quality samples were collected by wading the stream or suspending the sampler by hand from a bridge. Samples subsequently were processed onsite by using protocols similar to those described by Wells and others (1990). Onsite measurements included specific conductance, $\mathrm{pH}$, water and air temperature, and dissolved oxygen.

To obtain a representative ground-water sample, three casing volumes of water were removed from the well prior to the collection of a sample. Physical properties of specific conductance, $\mathrm{pH}$, water temperature, and dissolved oxygen were measured at 5-minute intervals using a flow-through chamber. Samples were collected after these physical property values stabilized or after at least three casing volumes had been pumped out of the well.

Samples to be analyzed for major ions, nitrogen, and radon were collected, preserved, and transported in accordance with the methods described in Pritt and Jones (1990), Wells and others (1990), and Verstraeten and others $(1995 ; 1999)$. Water samples were processed and preserved onsite and analyzed at various USGS laboratories.

Discharge measurements for the Interstate $\mathrm{C} \approx$ nal (site SW1) and Tri-State Canal (site SW3) were obtained from Wyoming Water Control Office personnel in Torrington, Wyoming. Discharge for the North Platte River at Wyoming-Nebraska State line (site SW2) and Horse Creek near Lyman (site SW'6), which are active gaging stations, was estimated b:" using the gage height with the shift indicated by the most recent measurement and the current rating as described by Rantz (1982). Discharges for Dry Sheep Creek (site SW7), Sheep Creek (site SW8), the North Platte River at Morrill (site SW9), and Akers Draw (SW10) and were determined by making streamflow measurements as described by Carter and Davidian (1968) at the time of water-quality sample collection.

A total of 137 samples were collected from the 11 representative surface-water sites. The North $F^{\prime}$ atte River at Morrill (site SW9) was sampled most often, 37 times from 1996 through 1999. In 1999, water samples from surface-water bodies contributing vater to the North Platte River in the study area, except the wetlands site (SW11), were collected to evaluate the sources of uranium in surface water (Verstraeten and others, 2001). A total of about 1,960 ground-water samples were collected from 1996 through 1999 . The number of samples collected at a specific well varied from 1 at well $2 \mathrm{~T}$, constructed in 1999, to 36 at well $1 \mathrm{C}-3$, constructed in 1994.

\section{Analytical Methods}

Water samples were analyzed at the USGS National Water Quality Laboratory (NWQL) in Denver, Colorado, and the USGS Dissolved-Gas, Chlorofluorocarbon, Isotope, and Uranium Research Laboratories in Reston, Virginia (table 3).

\section{Major Ions and Nitrogen Species}

Analyses of major ions and nitrogen species were completed at the USGS laboratory in Denver, Co'nrado, using standard methods (Fishman and Fried nan, 1989). Major ions were analyzed by inductively coupled plasma emission spectrometry (ICP). Dissolved nitrogen species were analyzed using colorimetric methods within 2 weeks of refrigerated storage, with the exception of a few surface-water samples that were analyzed after several months of 
Table 3. Selected water-quality constituents, reporting levels, analytical methods, references for analytical met'ods, and regulatory levels used for the study, Dutch Flats area, western Nebraska

[PMCL, Primary Maximum Contaminant Level; SMCL, Secondary Maximum Contaminant Level. Analytical method: ICP, inductively coupled plasma; UV, ultraviolet; IR, infrared; GC, gas chromatography; MS, mass spectrometry; AS, alpha particle spectrometry. NA, not applicable: mg/L., milligrams per liter; $\mu \mathrm{g} / \mathrm{L}$, micrograms per liter; $\mathrm{pCi} / \mathrm{L}$, picocuries per liter]

\begin{tabular}{|c|c|c|c|}
\hline Constituents & Reporting level & Analytical method & $\begin{array}{l}\text { Regulatory } \\
\text { levels }{ }^{1}\end{array}$ \\
\hline Calcium $^{2}$ & $0.02 \mathrm{mg} / \mathrm{L}$ & ICP & NA \\
\hline Magnesium $^{2}$ & $0.004 \mathrm{mg} / \mathrm{L}$ & ICP & NA \\
\hline Sodium $^{2}$ & $0.1 \mathrm{mg} / \mathrm{L}$ & ICP & NA \\
\hline Potassium $^{2}$ & $0.1 \mathrm{mg} / \mathrm{L}$ & ICP & NA \\
\hline Sulfate as sulfate ${ }^{2}$ & $0.1 \mathrm{mg} / \mathrm{L}$ & ICP & $250 \mathrm{SMCL}$ \\
\hline Chloride $^{2}$ & $0.1 \mathrm{mg} / \mathrm{L}$ & ICP & $250 \mathrm{SMCL}$ \\
\hline Fluoride $^{2}$ & $0.1 \mathrm{mg} / \mathrm{L}$ & ICP & $2.0 \mathrm{SMCL}$ \\
\hline Silica $^{2}$ & $0.1 \mathrm{mg} / \mathrm{L}$ & ICP & NA \\
\hline Ammonia as nitrogen ${ }^{2}$ & $0.2 \mathrm{mg} / \mathrm{L}$ & Colorimetry & NA \\
\hline Nitrite as nitrogen ${ }^{2}$ & $0.01 \mathrm{mg} / \mathrm{L}$ & Colorimetry & 1 PMCL \\
\hline Nitrite plus nitrate as nitrogen ${ }^{2}$ & $0.05 \mathrm{mg} / \mathrm{L}$ & Colorimetry & $\begin{array}{c}10 \text { PMCL } \\
\text { (nitrate only) }\end{array}$ \\
\hline Ammonia and organic nitrogen ${ }^{2}$ & $0.1 \mathrm{mg} / \mathrm{L}$ & Colorimetry & NA \\
\hline Dissolved and suspended organic carbon ${ }^{2}$ & $0.2 \mathrm{mg} / \mathrm{L}$ & Dohrman UV-promoted persulfate/IR & NA \\
\hline Carbon dioxide gas ${ }^{3}$ & $0 \mathrm{mg} / \mathrm{L}$ & Head space GC & NA \\
\hline Iron $^{2}$ & $10 \mu \mathrm{g} / \mathrm{L}$ & ICP & $300 \mathrm{SMCL}$ \\
\hline Manganese $^{2}$ & $4.0 \mathrm{mg} / \mathrm{L}$ & ICP & $50 \mathrm{SMCL}$ \\
\hline Organic carbon, dissolved ${ }^{2}$ & $0.33 \mathrm{mg} / \mathrm{L}$ & Dohrman UV-promoted persulfate/IR & NA \\
\hline Nitrogen gas $^{3}$ & $0 \mathrm{mg} / \mathrm{L}$ & Head space GC & NA \\
\hline Argon gas ${ }^{3}$ & $0 \mathrm{mg} / \mathrm{L}$ & Head space GC & NA \\
\hline Oxygen gas $^{3}$ & $0 \mathrm{mg} / \mathrm{L}$ & Head space GC & NA \\
\hline Methane gas ${ }^{3}$ & $0 \mathrm{mg} / \mathrm{L}$ & Head space GC & NA \\
\hline Uranium concentration $^{4}$ & $0 \pm 0.03$ to $0.3 \mu \mathrm{g} / \mathrm{L}$ & ICP/MS or AS & $30 \mathrm{MCL}$ \\
\hline Uranium activity ratio ${ }^{5}$ & $0 \pm 0.01$ to 0.10 & AS & NA \\
\hline Radon $^{6}$ & $70 \mathrm{pCi} / \mathrm{L}$ & Scintillation & $300 \mathrm{MCL}$ \\
\hline
\end{tabular}

\footnotetext{
${ }^{1}$ U.S. Environmental Protection Agency (2000).

${ }^{2}$ Fishman and Friedman (1989).

${ }^{3}$ Method is listed on Internet at http://water.usgs.gov/lab/dissolved.gas/Lab/index.html.

${ }^{4}$ U.S. Environmental Protection Agency (1994) or Thatcher and others (1977).

${ }^{5}$ Thatcher and others (1977).

${ }^{6}$ Whittaker and others (1989).
}

room-temperature storage by ion chromatography in the USGS laboratory in Reston, Virginia.

\section{Dissolved Gases}

Samples to be analyzed for dissolved gases were collected in $125 \mathrm{~mL}$ serum bottles with butyl rubber stoppers with no headspace and were sent to the USGS Dissolved-Gas Laboratory in Reston, Virginia. Lowpressure headspace was created in the laboratory by extracting approximately 8 percent of the water. Concentrations of argon, nitrogen, and methane gases were measured by gas chromatography (GC) on the headspace (URL http://water.usgs.gov/lab/dissolvedgas). Results for samples analyzed within 2 months of refrigerated storage were similar to results for samples preserved with potassium hydroxide.

\section{Chlorofluorocarbons}

Samples to be analyzed for chlorofluorccarbons (CFCs) were collected in flame-sealed glass ampules under pure nitrogen headspace (Busenberg and Plummer, 1992). CFCs were extracted in the USGS CFC Laboratory in Reston, Virginia, using a purgeand-trap procedure and analyzed by gas chromatogra- 
phy (http://water.usgs.gov/lab/cfc). Concentrations of CFC-11, CFC-12, and CFC-113 were converted to equilibrium partial pressures at local water-table altitudes at the equilibration temperatures indicated by argon and nitrogen gas concentrations. The partial pressures were compared to the atmospheric record to determine the apparent year of recharge (Plummer and Busenberg, 1999). Because some of the samples were from wells with long screens, potential effects of mixing were evaluated by comparison with tritium and helium isotope data (Cook and Böhlke, 1999).

\section{Tritium, Helium, and Neon Isotopes}

Samples to be analyzed for tritium $\left({ }^{3} \mathrm{H}\right) /$ helium-3 $\left({ }^{3} \mathrm{He}\right)$ age determination were collected in flowthrough copper tubes that were crimp sealed onsite. Helium and neon were extracted for mass spectrometric analysis, then degassed aliquots were re-analyzed after several months to determine ${ }^{3} \mathrm{H}$ concentrations from ${ }^{3} \mathrm{He}$ ingrowth at the Lamont-Doherty Earth Observatory of Columbia University, Noble Gas Laboratory in Palisades, New York (Ludin and others, 1998). The age of each ground-water sample (in years between the time of recharge and time of sampling) was assumed to be equal to the time indicated by decay of ${ }^{3} \mathrm{H}$ to ${ }^{3} \mathrm{He}$ in a closed system after adjustments for atmospheric gas contributions and for excess terrigenic helium (Schlosser and others, 1998) with an assumed ${ }^{3} \mathrm{He} /$ helium-4 $\left({ }^{4} \mathrm{He}\right)$ ratio of $2 \times 10^{-8}$ (Mamyrin and Tolstikhin, 1984). Temperatures used in the age calculations were determined from the concentrations of argon and neon, assuming those gases had only atmospheric sources. Adjustments for terrigenic helium were made only if the apparent concentrations of terrigenic ${ }^{4} \mathrm{He}$ were more than 5 percent of the total ${ }^{4} \mathrm{He}$ concentrations; values less than 5 percent were considered to have large relative uncertainties and result in anomalous age adjustments. Further adjustments for mixing of old and young water components commonly were made using samples from wells with long open intervals or with screens that intersect the water table, especially in fractured rock aquifers (such as Plummer and others, 1999). In the current study, most of the wells had relatively short screens at discrete depths in the alluvial aquifer where stable isotope data indicated that mixing of water from different sources was not widespread. Some of the ${ }^{3} \mathrm{H} /{ }^{3} \mathrm{He}$ and CFC data from wells with long screens near the water table were evaluated assuming piston flow (no mixing), or binary, linear, or exponential mixtures (Vogel, 1967; Cook and Böhlke, 1999; Plummer and others, 1999).

\section{Hydrogen and Oxygen Isotopes in Water}

Samples to be analyzed for hydrogen and oxygen isotopes in water were collected in $60-\mathrm{mL}$ glass bottles. At the USGS Stable Isotope Laboratory in Reston, Virginia, 2-mL aliquots were equilibrated with either hydrogen (for hydrogen isotopes) or carbon dioxide (for oxygen isotopes), which then were admitted to dedicated dual-inlet mass spectrometers. Hydrogen and oxygen isotope analyses were calibrated against analyses of laboratory reference water with known $\delta^{2} \mathrm{H}$ and $\delta^{18} \mathrm{O}$ values normalized to standard values of 0 and 0 for hydrogen and oxy'gen, respectively, in VSMOW (Vienna-Standard Mean Ocean Water), and -428 and -55.5 for hydrogen and oxygen, respectively, in SLAP (Standard Light Antarctic Precipitation) (Coplen, 1988). The data were evaluated by comparison to the "meteoric water line", $\delta^{2} \mathrm{H}=8 * \delta^{18} \mathrm{O}+\mathrm{d}$-excess (Craig, 1961; Dansgaard, 1964; International Atomic Energy Agency, 1981). Although the global average d-excess value in precipitation is +10 , local precipitation may have different values of $d$-excess, and evaporation may produce arrays of values with slopes less than 8. or lower apparent values of d-excess (Gonfiantini, 1986; International Atomic Energy Agency, 1992).

\section{Nitrogen Isotopes in Nitrate and Dissolved Nitrogen Gas}

Samples to be analyzed for isotopes of nitrate were collected in $1 \mathrm{~L}$ plastic bottles and frozen. At the USGS Stable Isotope Laboratory, Reston, Virginia, aliquots were freeze dried at high $\mathrm{pH}$, then loaded into pure silica glass tubes with $\mathrm{CaO}$ and $\mathrm{Cu}_{2} \mathrm{O}$; the tubes were evacuated, sealed, baked at $850^{\circ} \mathrm{C}$, and cosled slowly (Böhlke and Denver, 1995). Purified $\mathrm{N}_{2}$ gas in the tubes was expanded into a dual inlet mass sfectrometer and analyzed along with gas produced from dissolved nitrate standards prepared and analyzed as aqueous samples. Nitrate $\delta^{15} \mathrm{~N}$ data were normalized to standard values of +4.7 for International Atomic Energy Agency (IAEA)-N3 and +180.0 for USGS-32 (Böhlke and Coplen, 1995). For nitrogen isotop? analysis of dissolved $\mathrm{N}_{2}$, the headspace gases remaining after gas chromatographic analysis at the USGS Dissolved Gas Laboratory in Reston, Virginia, v'ere sealed into evaculated glass tubes with $\mathrm{CaO}$ and $\mathrm{Cu}_{2} \mathrm{O}$, 
baked, cooled slowly, then admitted to the mass spectrometer and analyzed along with air samples $\left(\delta^{15} \mathrm{~N}=0\right)$ and with headspace samples from laboratory-equilibrated water samples $\left(\delta^{15} \mathrm{~N}=+0.65 \pm 0.10\right)$. The overall accuracy and precision of the $\mathrm{N}_{2}$ isotope analyses were estimated to be approximately \pm 0.2 or better for nitrate and \pm 0.1 or better for $\mathrm{N}_{2}$ (Böhlke and Coplen, 1995).

\section{Uranium and Uranium Activity Ratios}

Water samples to be analyzed for dissolved uranium were collected in polyethylene bottles, filtered, and acidified. Two different techniques were used to analyze for uranium concentrations and the uranium isotopic ratio ${ }^{234} \mathrm{U} /{ }^{238} \mathrm{U}$ or uranium activity ratio (UAR). The two techniques, alpha particle spectroscopy (AS) and ICP/mass spectrometry (MS), were performed at the USGS Uranium Research Laboratory in Reston, Virginia. To analyze the dissolution of uranium from sediment samples, a representative 1-g sample was leached for about 24 hours in $500 \mathrm{~mL}$ distilled water containing $0.5 \mathrm{~g}$ sodium bicarbonate.

For AS analyses, a 500-mL aliquot was taken, spiked with uranium-232 $\left({ }^{232} \mathrm{U}\right)$, processed by iron hydroxide precipitation and anion-ion exchange, and then electroplated onto a stainless-steel planchette for counting, using a solid-state, partially depleted silicon detector (Ivanovich and Murray, 1992). The second method, using ICP/MS, was developed during the course of this investigation and allowed a more precise determination of uranium and UAR values on a smaller volume of sample (Thomas F. Kraemer and Michael W. Doughton, U.S. Geological Survey, written commun., 2000) than AS. In this method, uranium concentrations in the sample were determined first using uranium-236 $\left({ }^{236} \mathrm{U}\right)$ as an internal standard. Upon determining the concentration, a measured volume of sample was selected for ${ }^{234} \mathrm{U} /{ }^{238} \mathrm{U}$ analysis that would produce acceptable ICP/MS performance. The volume of water was evaporated to dryness and redissolved in a $8 \mathrm{~N}$ (normal) hydrochloric acid (liquid phase) solution. The uranium then was separated by a simple anion-exchange procedure. The uranium was eluted into a $30-\mathrm{mL}$ bottle with $0.1 \mathrm{~N}$ hydrogen chloride and distilled water, which then was injected into the ICP/MS unit using an ultrasonic nebulizer. Precision and accuracy for the uranium analyses by AS were approximately 3 percent and, for UAR by AS, were 5 to 7 percent. Using the ICP/MS technique, the precision and accuracy were less than 1 and 0.5 percent, respectively.

\section{Calculation of Recharge Temperatures, Fixcess Air, and Excess Nitrogen in Ground Water}

The apparent recharge temperature and amount of excess air were calculated for each sample from the concentrations of argon and neon by assuming two dissolved-gas components (Aeschbach-Hertig and others, 1999; Stute and Schlosser, 1999): (1) from air equilibration at the altitude of the water tab ${ }^{1}$, and 100 percent relative humidity; and (2) from unfractionated excess air introduced during recharge or sampling. This calculation was done for earh sample by solving iteratively an equation relating tl ? measured concentrations of argon and neon to a common equilibration temperature and excess air quantity:

$$
\begin{gathered}
\text { Excess air ccSTP/L }=\left\{[\mathrm{Ar}]_{\text {measuared }}-[\mathrm{Ar}(\mathrm{T}, \mathrm{el} \cdot \mathrm{v})]_{\mathrm{asw}}\right\} / \\
0.417 \mu \mathrm{mol}_{\mathrm{Ar}}{ }^{/ \mathrm{cc}_{\text {air }}}=\left\{[\mathrm{Ne}]_{\text {meas }}-[\mathrm{Ne}(\mathrm{T}, \text { eler })]_{\mathrm{asw}}\right\} / \\
0.000811\left(\mu \mathrm{mol}_{\mathrm{Ne}}\right) / \mathrm{cc} \mathrm{c}_{\text {air }}
\end{gathered}
$$

where

ccSTP/L is cubic centimeters per liter at standard temperature and pressure;

$[\mathrm{Ar}, \mathrm{Ne}]_{\text {meas }}$ is the measured concentration of argon or neon in the sample (in micromoles per liter $(\mu \mathrm{mol} / \mathrm{L})$; and

$[\mathrm{Ar}, \mathrm{Ne}(\mathrm{T}, \mathrm{elev})]_{\mathrm{asw}}$ is the concentration of argon or neon in air-saturated water at the temperature and altitud of the water table (calculated using argon and neon solubility data from Weiss, 1970, 1971).

For comparison with the argon and neon data, the apparent recharge temperature and amount of excess air also were calculated similarly for each sample from the concentrations of argon and nitrogen, with nitrogen solubility data from Weiss (1970). For samples with relatively high oxygen concentrations, recharge temperatures and excess air quantities calculated from argon and neon data and from argon and nit*ogen data generally were in agreement to within the uncertainty of the methods. However, for some of the samples with low oxygen concentrations (less than $50 \mu \mathrm{mol} / \mathrm{L}$ ), 
there was disagreement between the two calculations that could be accounted for by assuming that the oxygen-depleted samples contained an additional nonatmospheric component of nitrogen.

Therefore, concentrations of excess nitrogen were calculated for each sample by using the recharge temperature and excess air values derived from argon and neon data:

$$
\begin{aligned}
& \text { Excess } \mathrm{N}_{2} \text { in } \frac{\mu \mathrm{mol}}{\mathrm{L}}=\left[\mathrm{N}_{2}\right] \text { meas }-\left[\mathrm{N}_{2}(\mathrm{~T}, \text { elev })\right]_{\text {asw }}{ }^{-} \\
& \text {[Excess air in ccSTP/L }]^{*} 34.8 \mu \mathrm{mol} \mathrm{N}_{2} / \mathrm{cc}_{\text {air }} \text {. }
\end{aligned}
$$

Results indicate that the practical detection limit for excess nitrogen was approximately $18 \mu \mathrm{mol} / \mathrm{L}$.

\section{Quality Assurance and Quality Control}

USGS onsite and laboratory quality-assurance (QA) and quality-control (QC) guidelines were followed throughout this study. These guidelines are necessary to assess whether or not contamination occurred and, if present, whether it occurred onsite or in the laboratory. Therefore, $134 \mathrm{QC}$ samples (6.5 percent of the total 2,092 samples) were collected. QC samples collected onsite included 58 equipment blanks, 75 duplicates, and 1 spiked sample (Inorganic PotableWatR ${ }^{\mathrm{TM}}$, Lot No. 3423). Each USGS laboratory follows stringent $\mathrm{QA} / \mathrm{QC}$ procedures, dependent on the analytical method used for chemical analysis. In addition, cation-anion balances of all samples analyzed for major ions were checked by comparing them.

\section{ANALYTICAL RESULTS}

This section lists selected analytical results not published in previous USGS reports (tables 4 through 7). Specifically, dissolved gases, age-dating data, and other isotopes collected as part of an intensive sampling effort in August and November 1998 and all uranium and uranium isotope data collected through the course of this study (1995 to 1999) have been included in these tables.

With respect to QA/QC of the cation/anion balances, all samples were rated as acceptable because they were within 10 percent of each other. Analytical results of equipment blanks for major ions and nitrate concentrations generally were acceptable. Nitrate concentrations in blank samples varied from less than the detection level of $0.05 \mathrm{mg} / \mathrm{L}$ as nitrogen $\left(26 \mathrm{o}^{f}\right.$ 58 samples or 45 percent) to $0.30 \mathrm{mg} / \mathrm{L}$ as nitrogen. All but two blank samples had concentrations less than $0.10 \mathrm{mg} / \mathrm{L}$ as nitrogen.

The differences in nitrate concentrations between the 60 environmental samples and their duplicate samples varied from 0 ( 0 percent) to $5.0 \mathrm{mg} / \mathrm{L}$ (38 percent) with a median of $0.19 \mathrm{mg} / \mathrm{L}$ ( 1.7 perc $\odot n t)$. All but one set of replicate samples had a difference in concentration less than $0.50 \mathrm{mg} / \mathrm{L}$, with larger differences generally observed at larger nitrate concent"ations. A Wilcoxon rank-sum test indicated that these differences were not statistically significant (60 sets of replicates with p-value of 0.6782 ). Using a 95-percent confidence interval, $\mathrm{p}$-values of 0.05 or less indicate that the medians of the populations being considered are significantly different. The nitrate concentration in the spiked reference sample was $7.6 \mathrm{mg} / \mathrm{L}$ instead of the expected $7.5 \mathrm{mg} / \mathrm{L}$, a difference of 1.4 percen $^{+}$, or $0.10 \mathrm{mg} / \mathrm{L}$. This analytical result is well within the acceptable performance limit for nitrate.

To investigate whether the use of bentonite in well-construction materials would affect the chem istry of the ground-water samples, especially the amounts of radon and uranium, well $1 \mathrm{~B}-2$ was sampled twice (generally within 0.5 hour) when well $1 \mathrm{~B}-1$ was sampled. Samples from these two wells were anclyzed for radon (two samples), uranium (one samnle), and nitrate (two samples) among other constituents, depending upon the particular sample collection. Comparison of the water chemistry between well $1 \mathrm{~B}-1$ and well $1 \mathrm{~B}-2$ indicated that well construction with bentonite did not affect the activity of radon present in the water. The differences in analytical results for radon were 16 ( 5 percent) and 53 ( 15 percent) $\mathrm{pCi} / \mathrm{L}$, both less than or near the analytical error of two standard deviations of 22 and $21 \mathrm{pCi} / \mathrm{L}$, respectively. The differences in uraniun concentrations were $0.9 \mu \mathrm{g} / \mathrm{L}$ or 6 percent. The differences in nitrate concentrations were 0.61 (19 percent) and $0.49 \mathrm{mg} / \mathrm{L}$ ( 5 percent). These results indicate that the use of bentonite in well construction did not affect the ground-water chemistry of the samples collected, but that small variations in ground-water chemist"y can occur over short distances. 


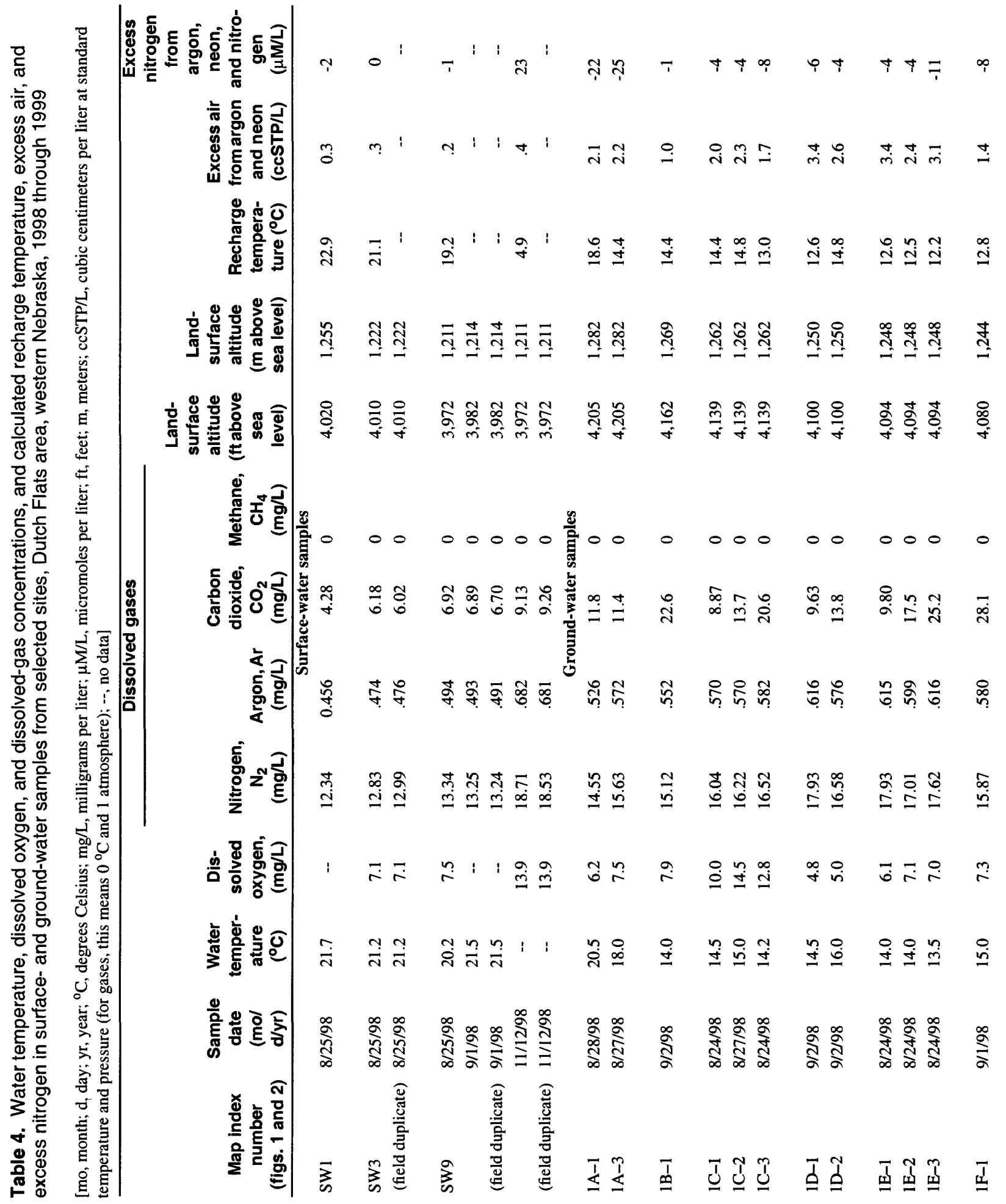




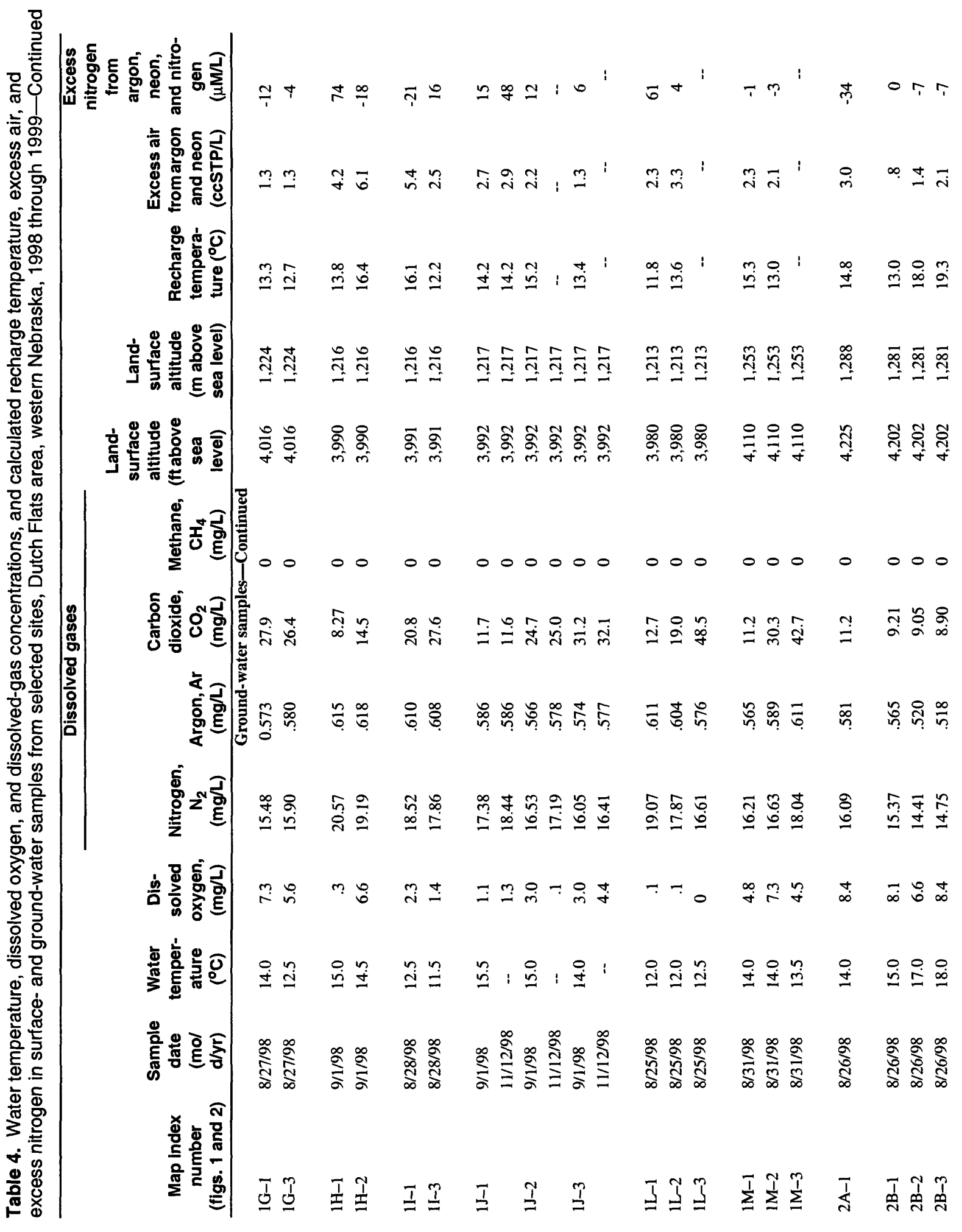




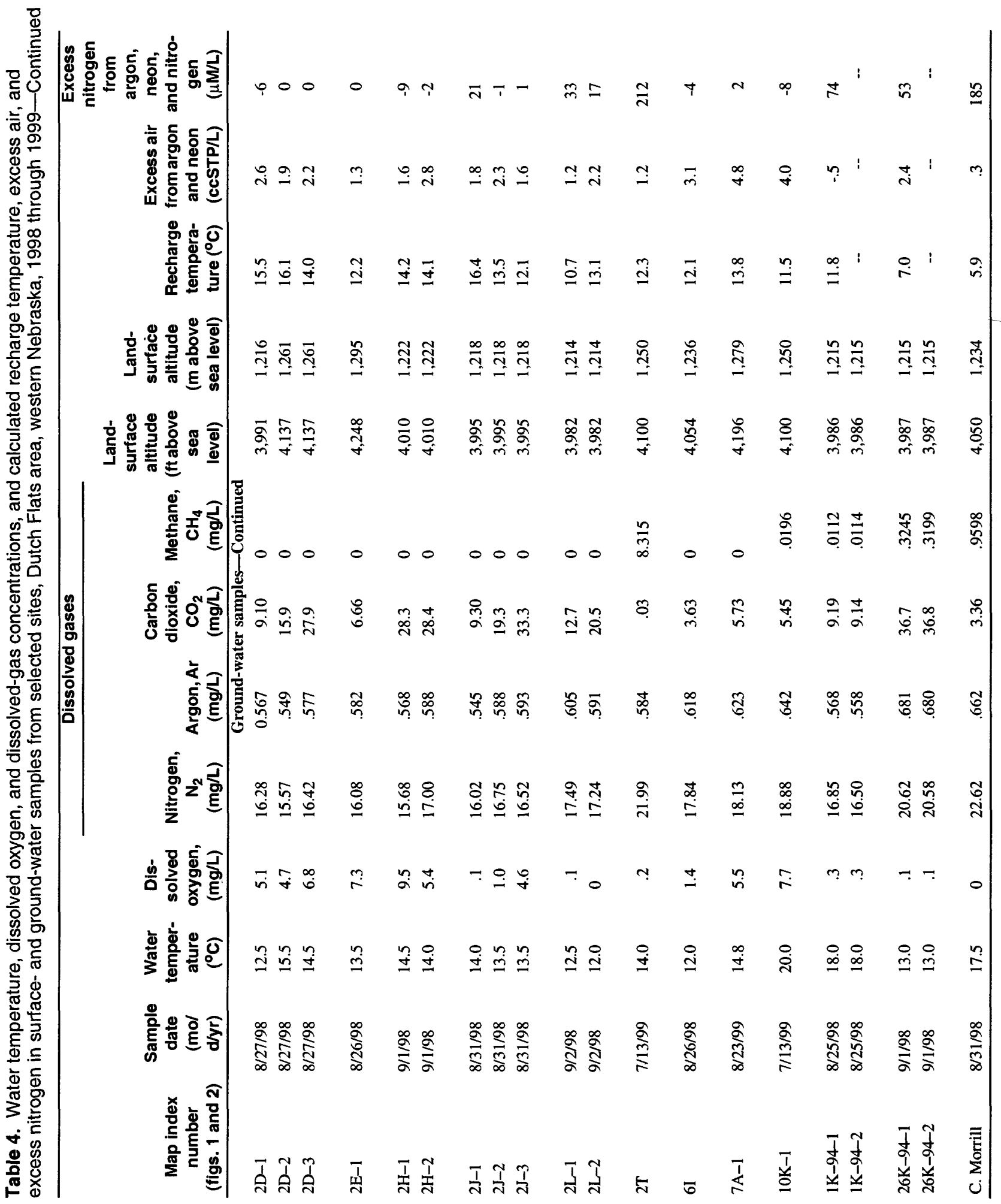




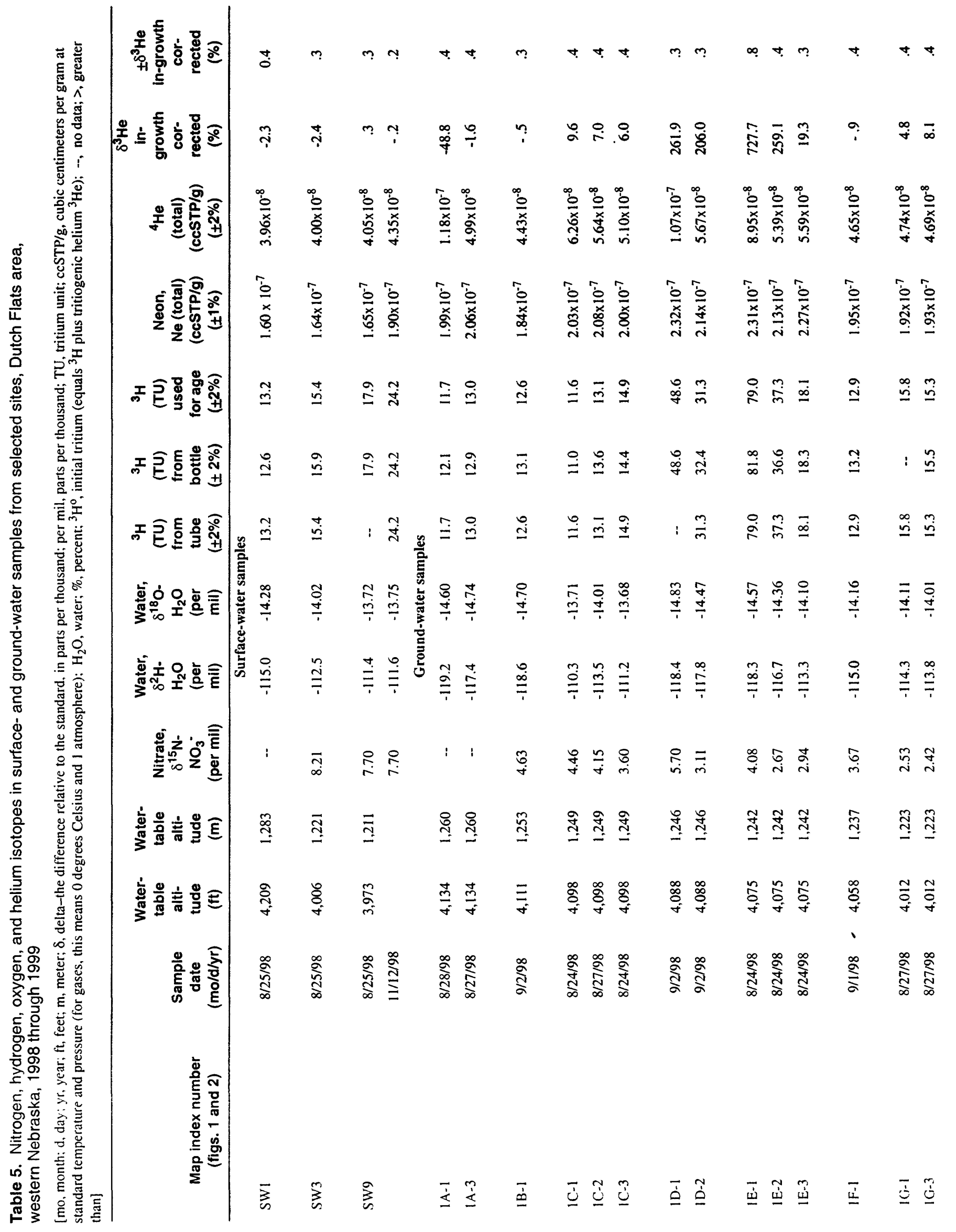




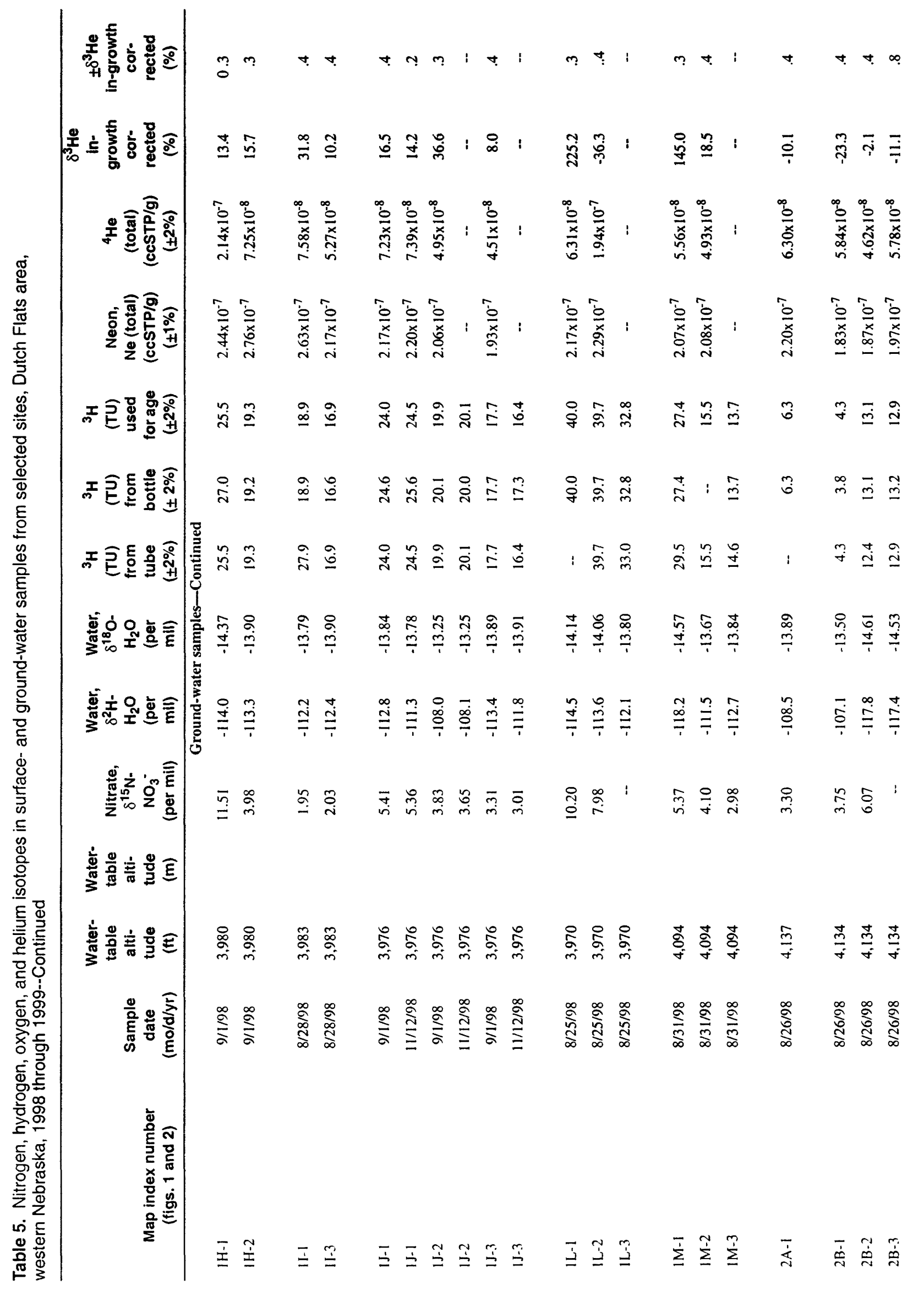




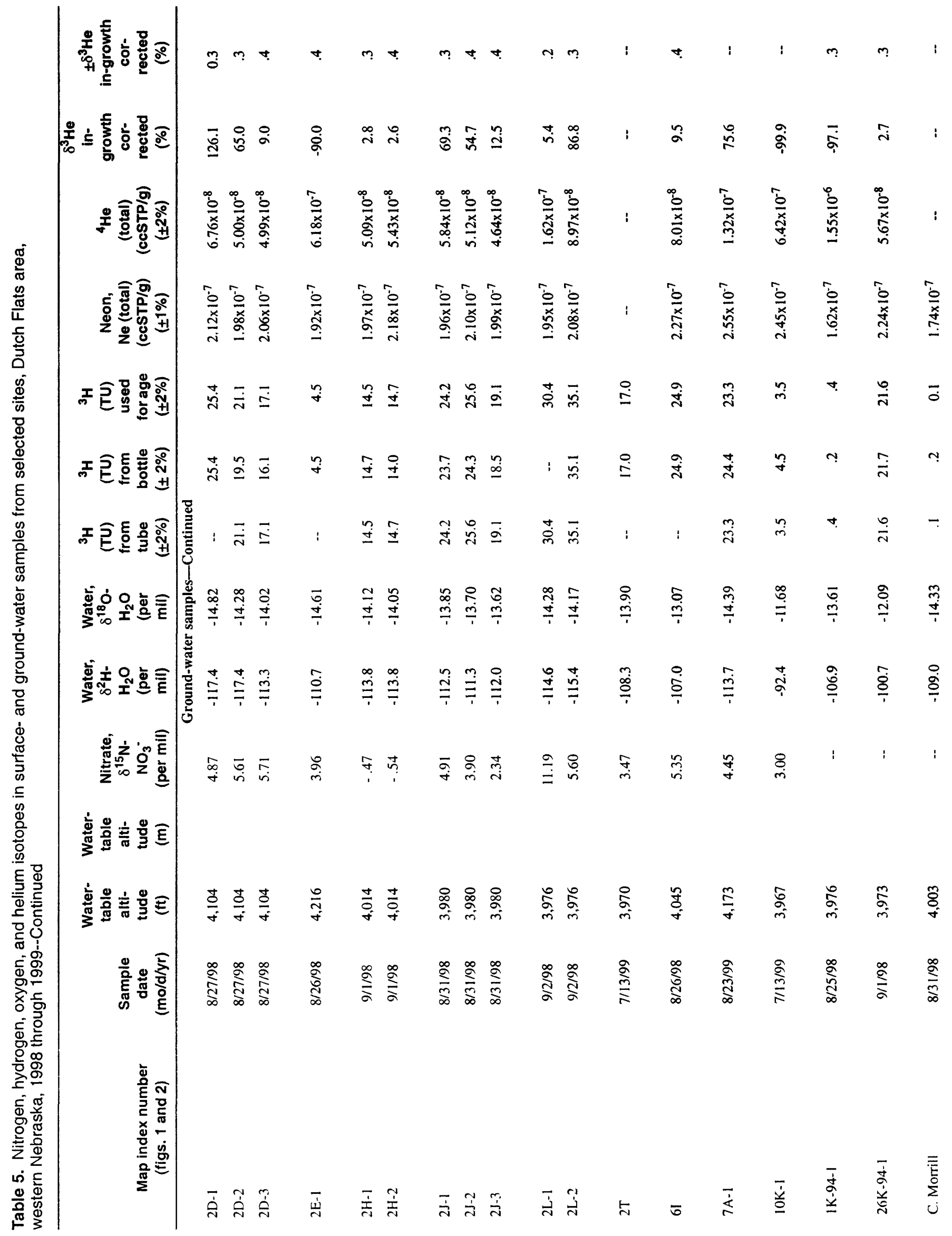




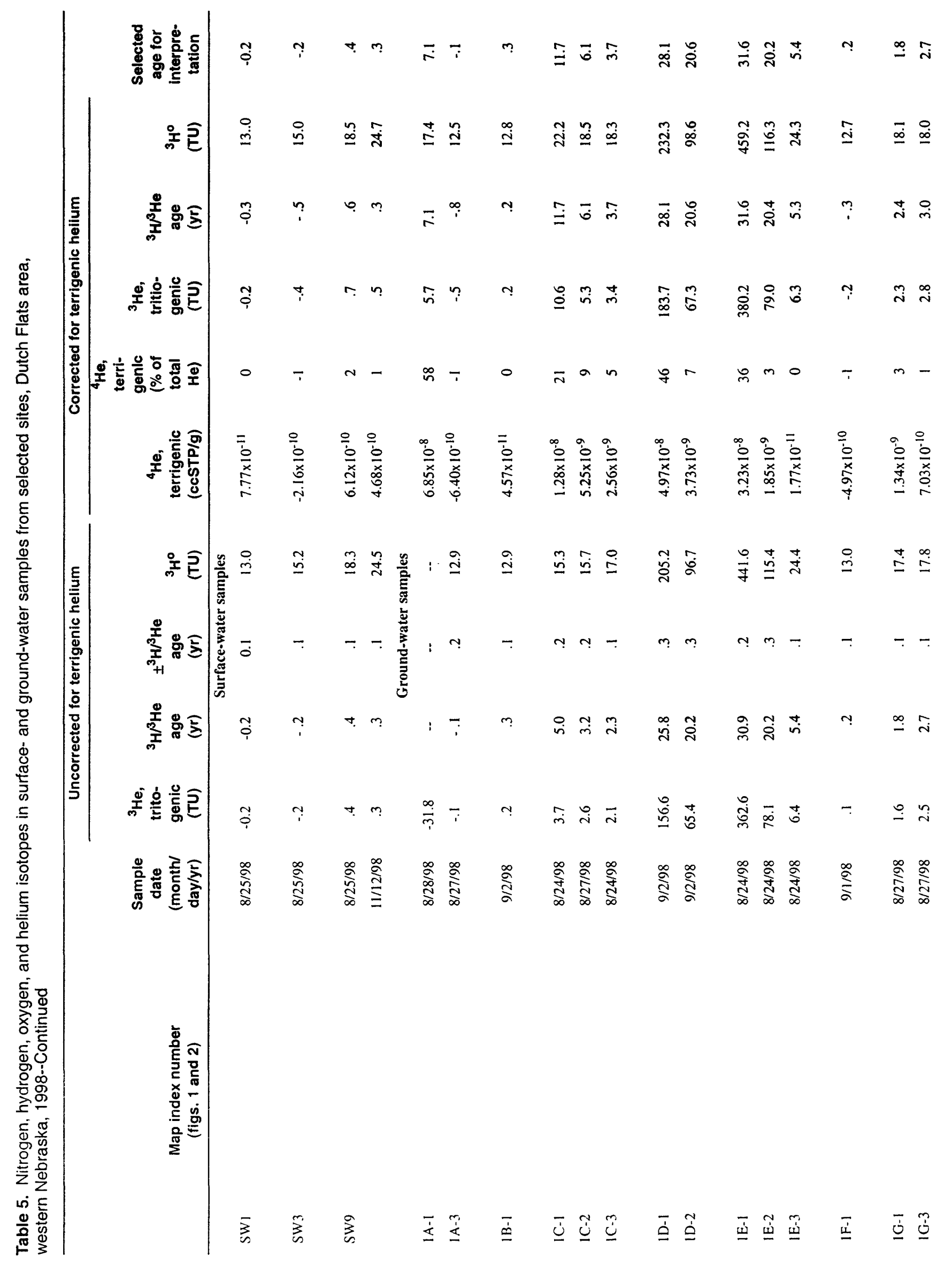




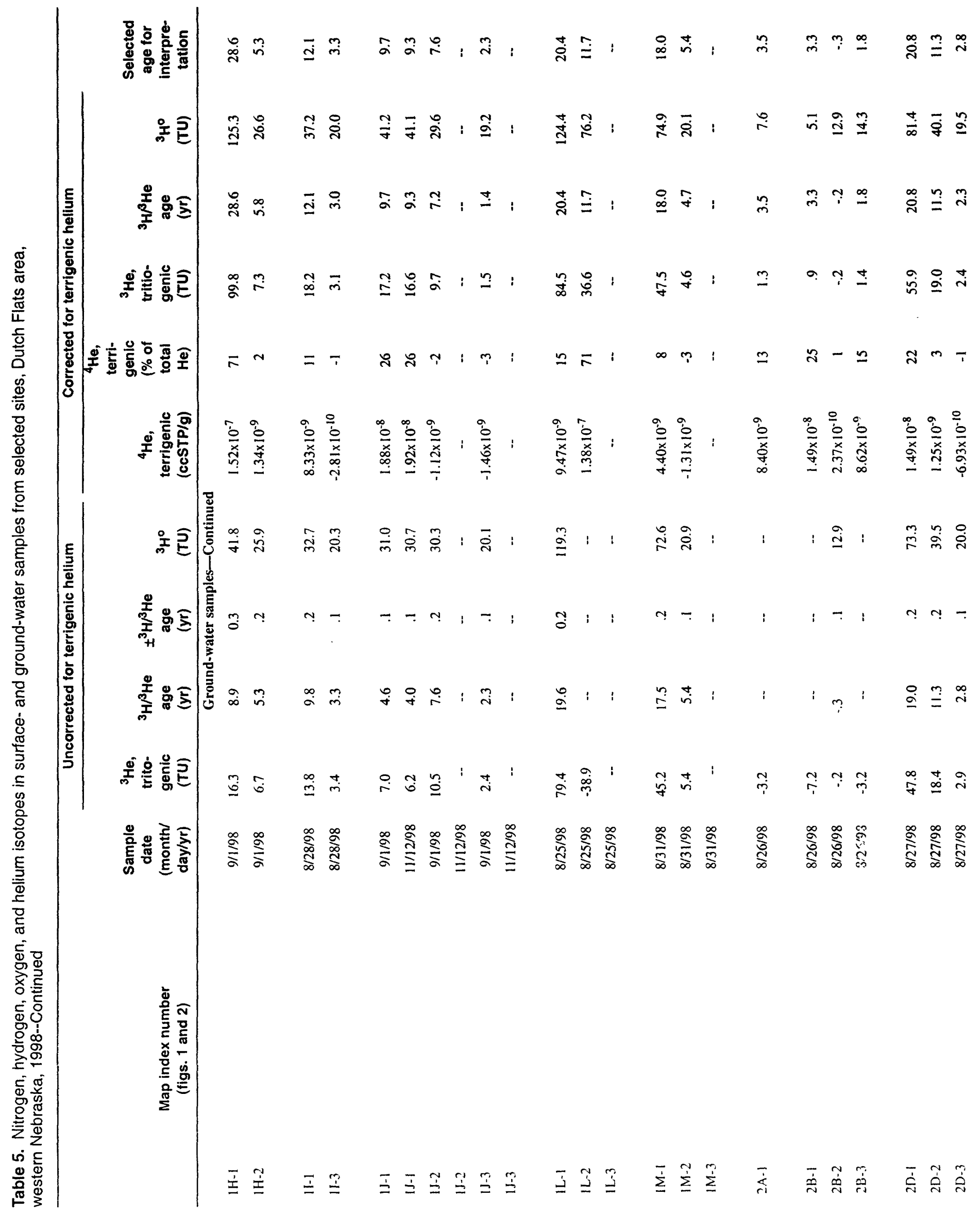




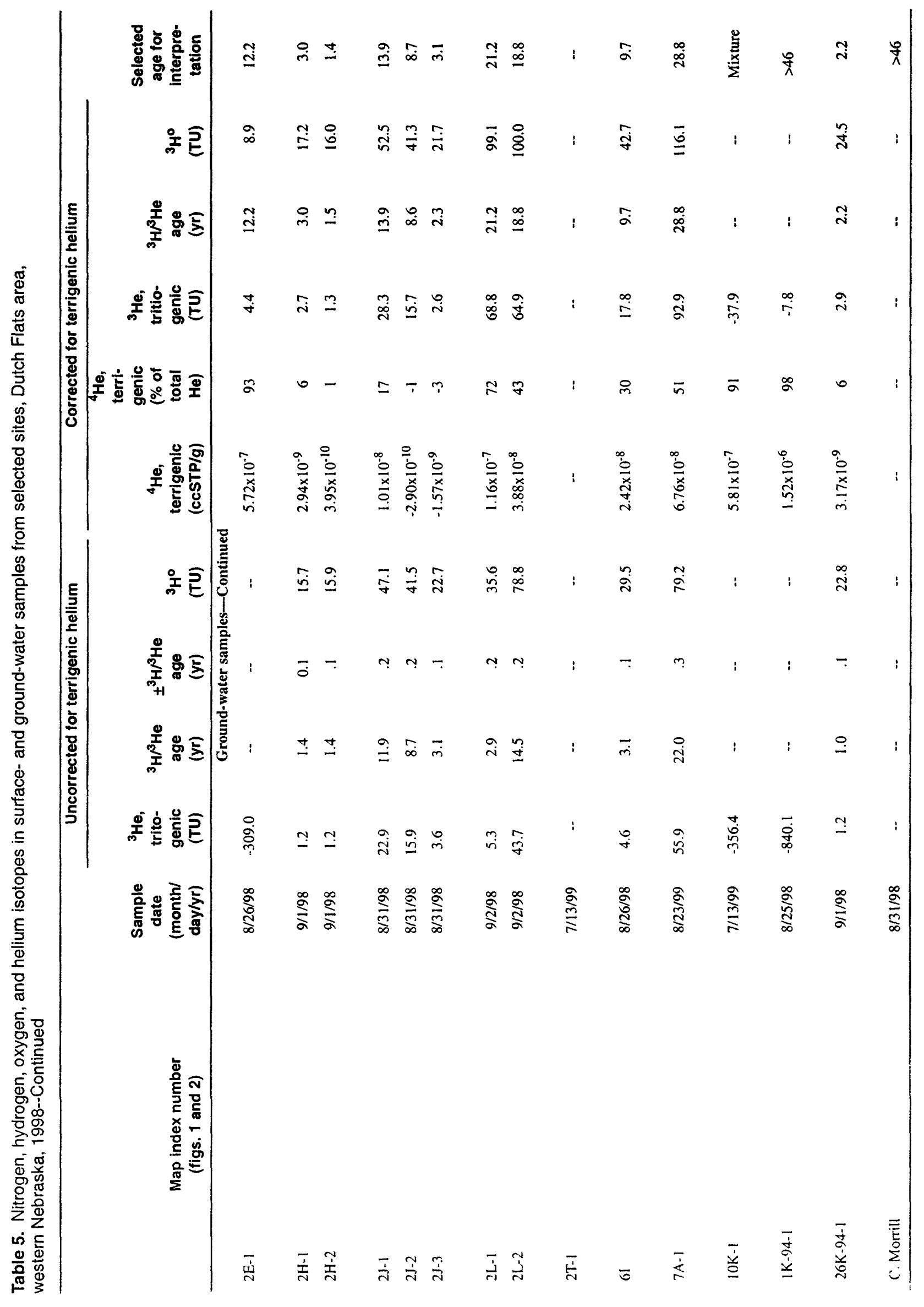


Table 6. Chlorofluorocarbons in surface- and ground-water samples from selected sites, Dutch Flats area, western Nebraska, 1998

[mo, month; d, day; yr, year; CFC, chlorofluorocarbon; pg/kg, picograms per kilogram; $\sigma$, sigma-the standard deviation; --, no data]

\begin{tabular}{|c|c|c|c|c|c|c|c|c|}
\hline $\begin{array}{c}\text { Map index } \\
\text { number } \\
\text { (figs. } 1 \text { and 2) }\end{array}$ & $\begin{array}{c}\text { Sample date } \\
\text { (mo/d/yr) }\end{array}$ & $\begin{array}{l}\text { CFC-11 } \\
(\mathrm{pg} / \mathrm{kg})\end{array}$ & $\begin{array}{c} \pm 1 \sigma \\
\text { CFC-11 } \\
(\mathrm{pg} / \mathrm{kg})\end{array}$ & $\begin{array}{l}\text { CFC-12 } \\
(\mathrm{pg} / \mathrm{kg})\end{array}$ & $\begin{array}{c} \pm 1 \sigma \\
\text { CFC-12 } \\
(p g / k g)\end{array}$ & $\begin{array}{c}\text { CFC-113 } \\
\text { (pg/kg) }\end{array}$ & $\begin{array}{c} \pm 1 \sigma \\
C F C-113 \\
(\mathrm{pg} / \mathrm{kg})\end{array}$ & $\begin{array}{c}\text { Age, suggested, } \\
\text { CFC data } \\
\text { (yr) }\end{array}$ \\
\hline \multicolumn{9}{|c|}{ Surface-water sample } \\
\hline SW9 & $8 / 25 / 98$ & 424.2 & 2.3 & 212.8 & 15.9 & 59.7 & 11.0 & Modern water \\
\hline \multicolumn{9}{|c|}{ Ground-water sanples } \\
\hline 1E-1 & $8 / 24 / 98$ & 66.4 & .8 & 39.8 & .5 & 43.9 & - & Mid-1960s \\
\hline $1 E_{-2}$ & $8 / 24 / 98$ & 352.2 & 5.7 & 168.5 & 3.8 & 59.7 & 2.6 & Early $1980 \mathrm{~s}$ \\
\hline $1 \mathrm{~J}-1^{l}$ & $9 / 1 / 98$ & 59.9 & 2.6 & 162.5 & 6.7 & 1.5 & 1.3 & Early to mid-1980s \\
\hline $1 \mathrm{~J}-2^{1}$ & 9/1/98 & 469.9 & 5.3 & 286.0 & 10.0 & 51.9 & 6.3 & Late 1980 s \\
\hline y-3 & $9 / 1 / 98$ & 490.6 & 2.2 & 252.9 & 5.8 & 104.4 & 11.1 & Early to mid- $1990 \mathrm{~s}$ \\
\hline $1 M-1$ & $8 / 31 / 98$ & 301.0 & 1.7 & 183.2 & 7.2 & 10.8 & 2.6 & 1980 \\
\hline $1 \mathrm{M}-2$ & $8 / 31 / 98$ & 499.2 & 7.6 & 235.7 & 16.6 & 67.0 & 9.1 & Late 1980 s to early $1990 \mathrm{~s}$ \\
\hline $1 \mathrm{M}-3$ & $8 / 31 / 98$ & 527.0 & 10.4 & 269.3 & 8.8 & 592.3 & 149.5 & Mid-1990s \\
\hline
\end{tabular}

${ }^{1}$ Data for wells $1 \mathrm{~J}-1$ and $1 \mathrm{~J}-2$ originally were inconsistent with other measurements from this well nest; therefore, the data were switched, wl ich made them consistent with the other analytical results. 


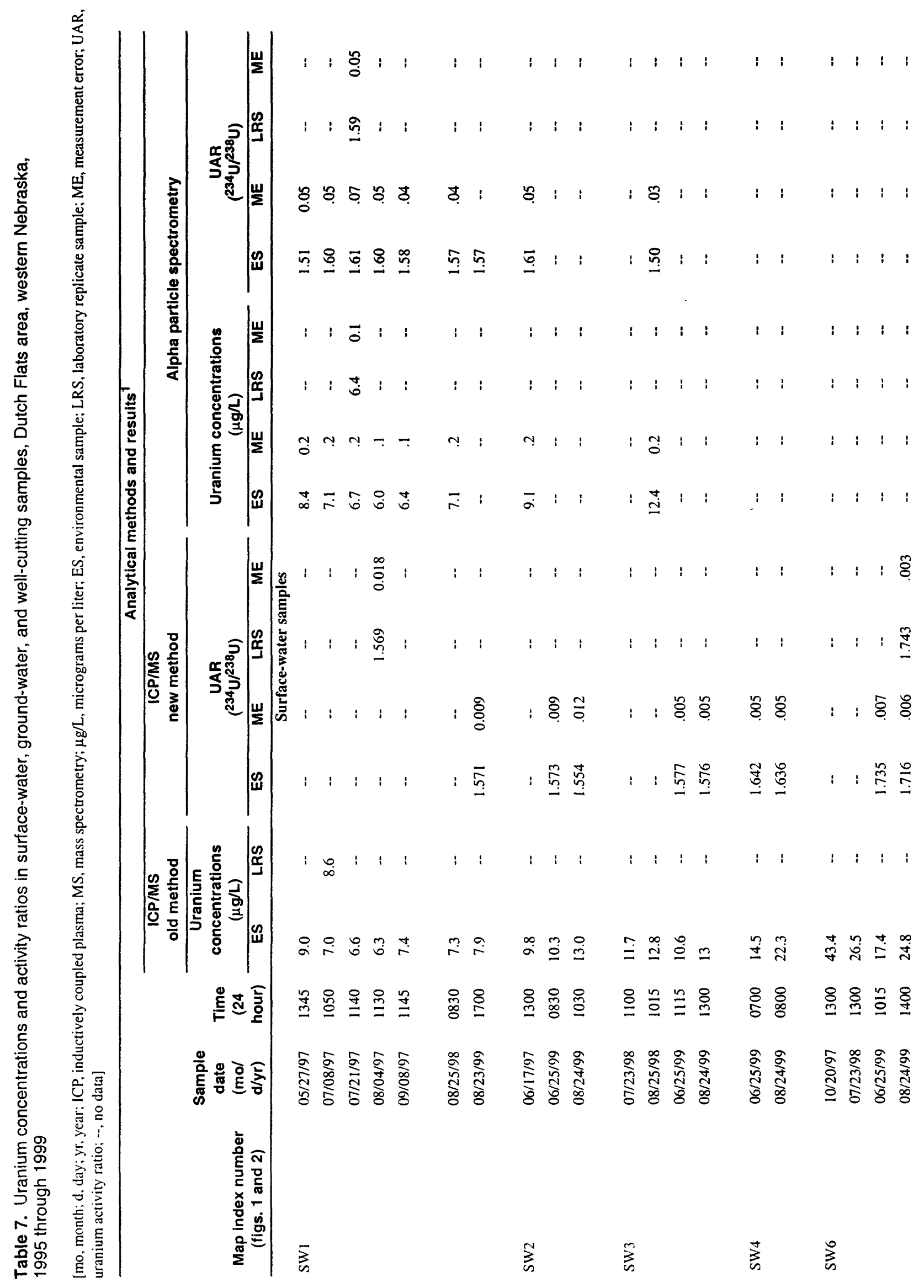




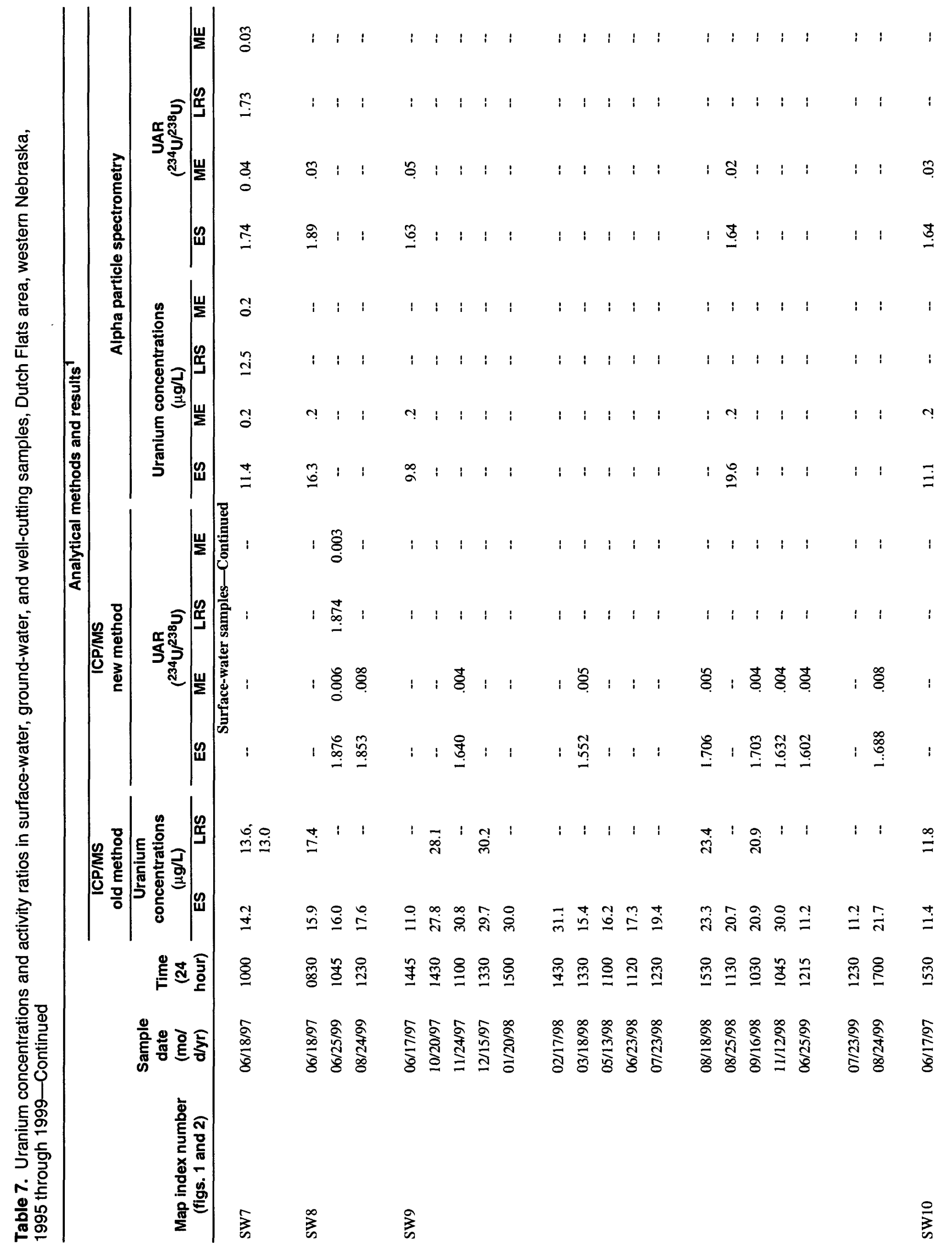




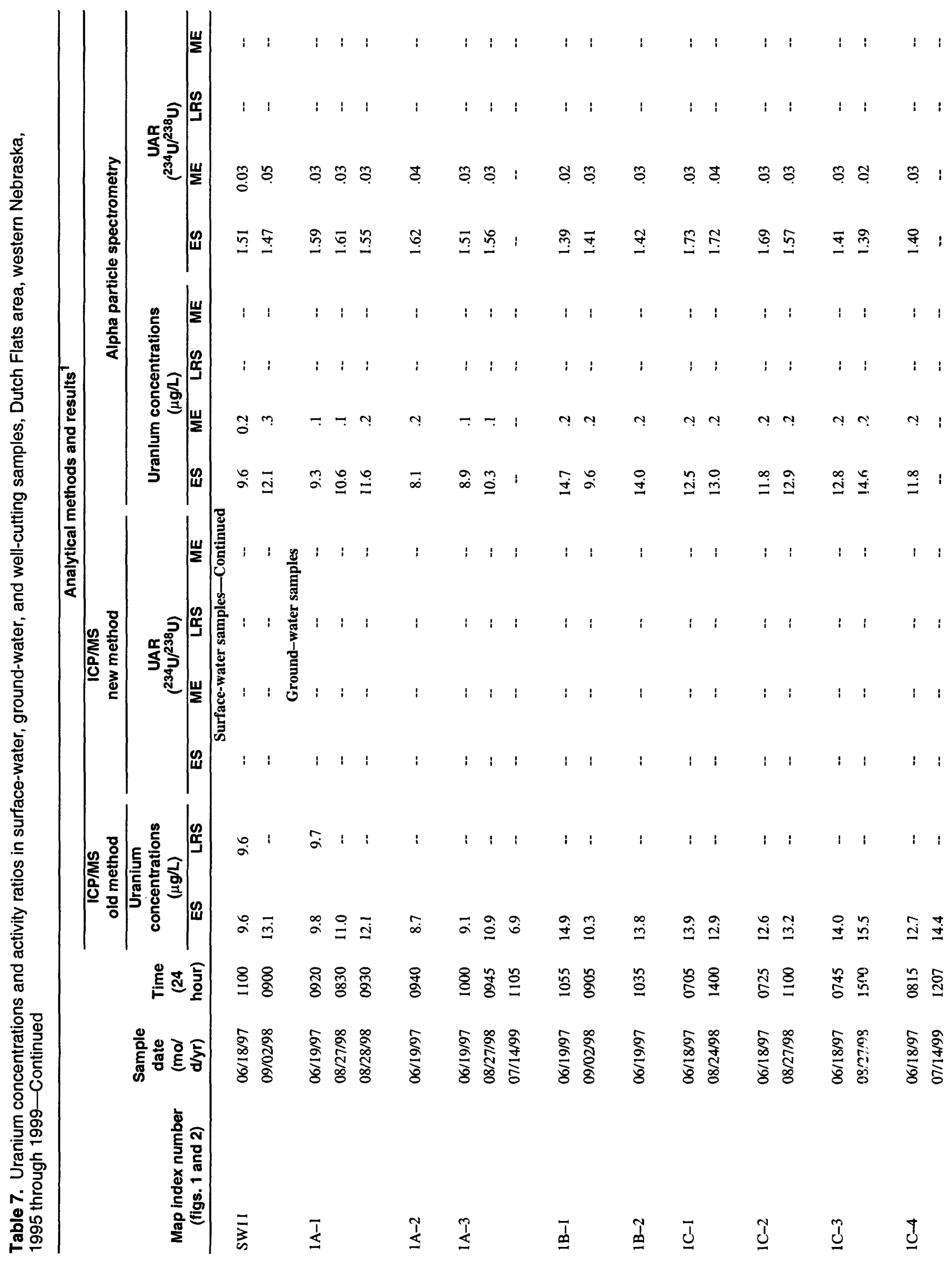

32 Selected Field and Analytical Methods and Analytical Results in the Dutch Flats Area, Western Nebraska, 1995-9? 


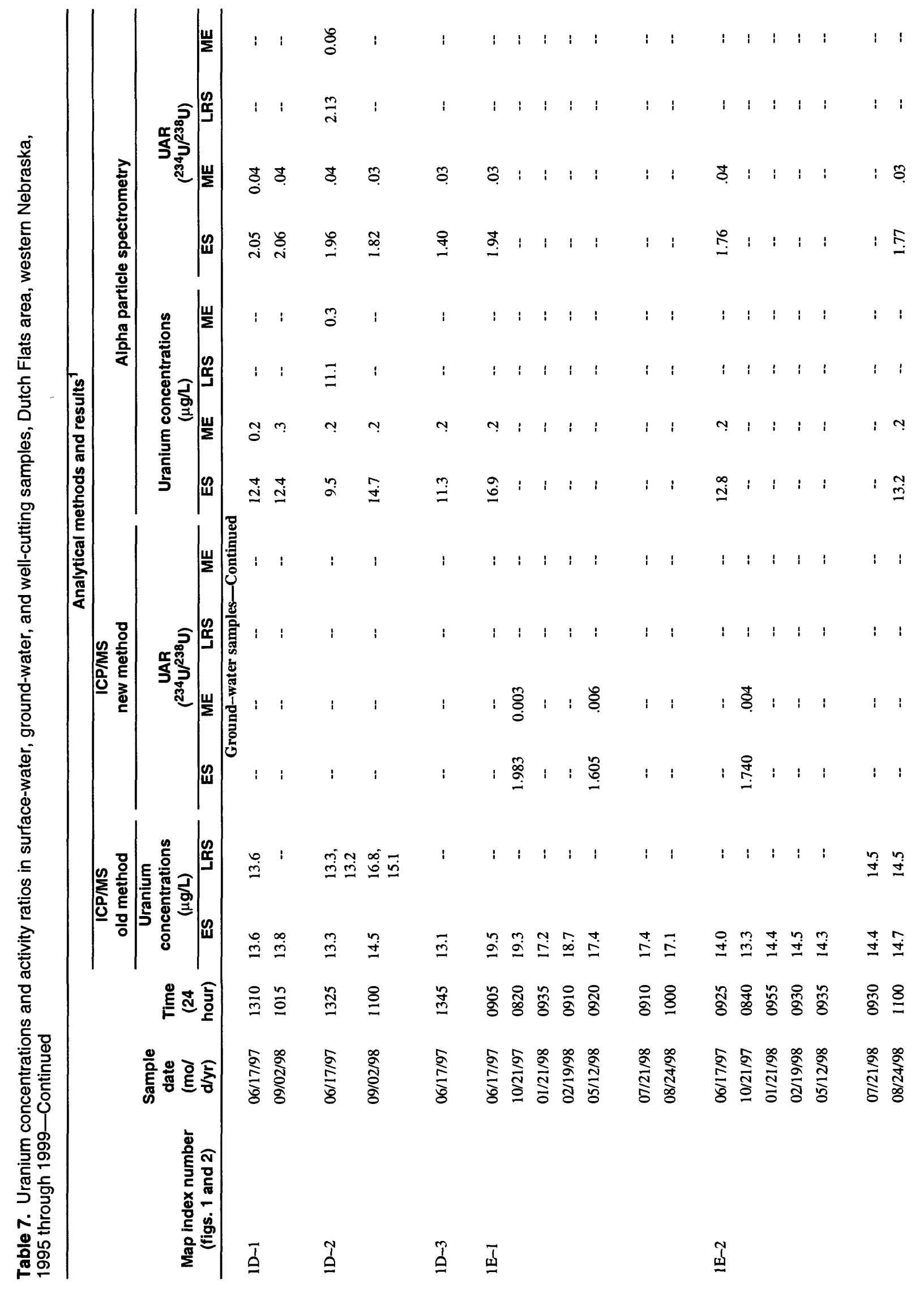




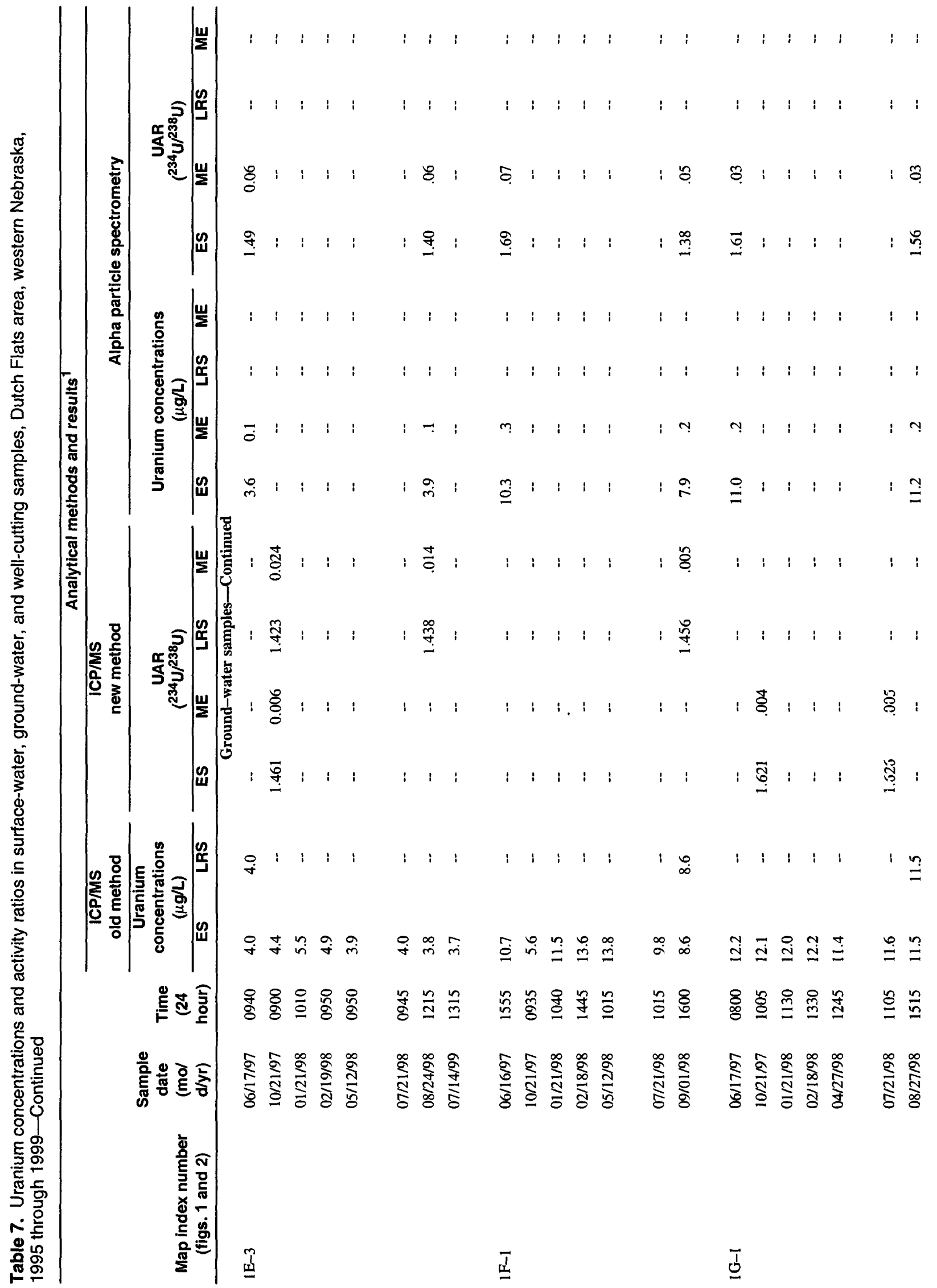




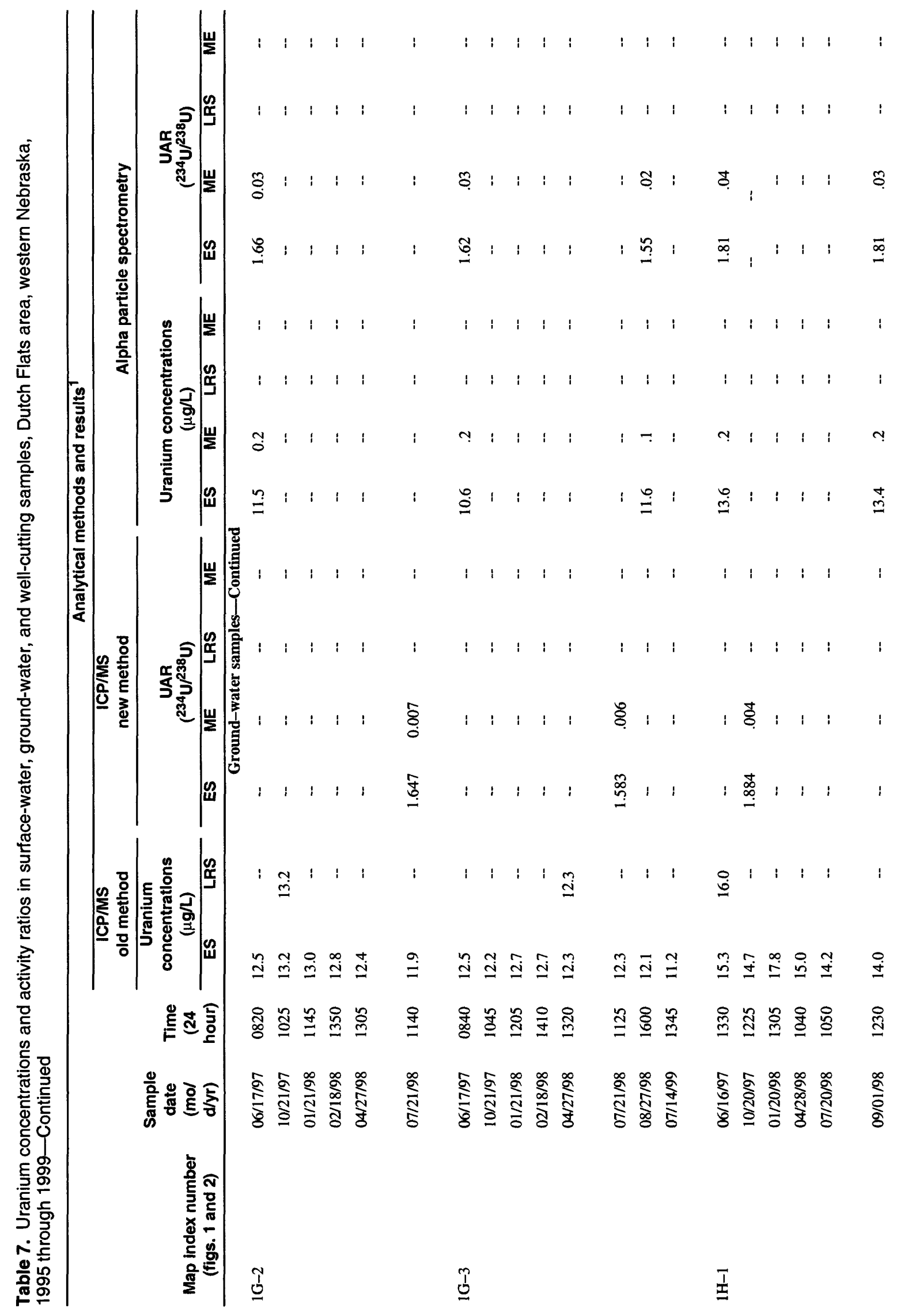




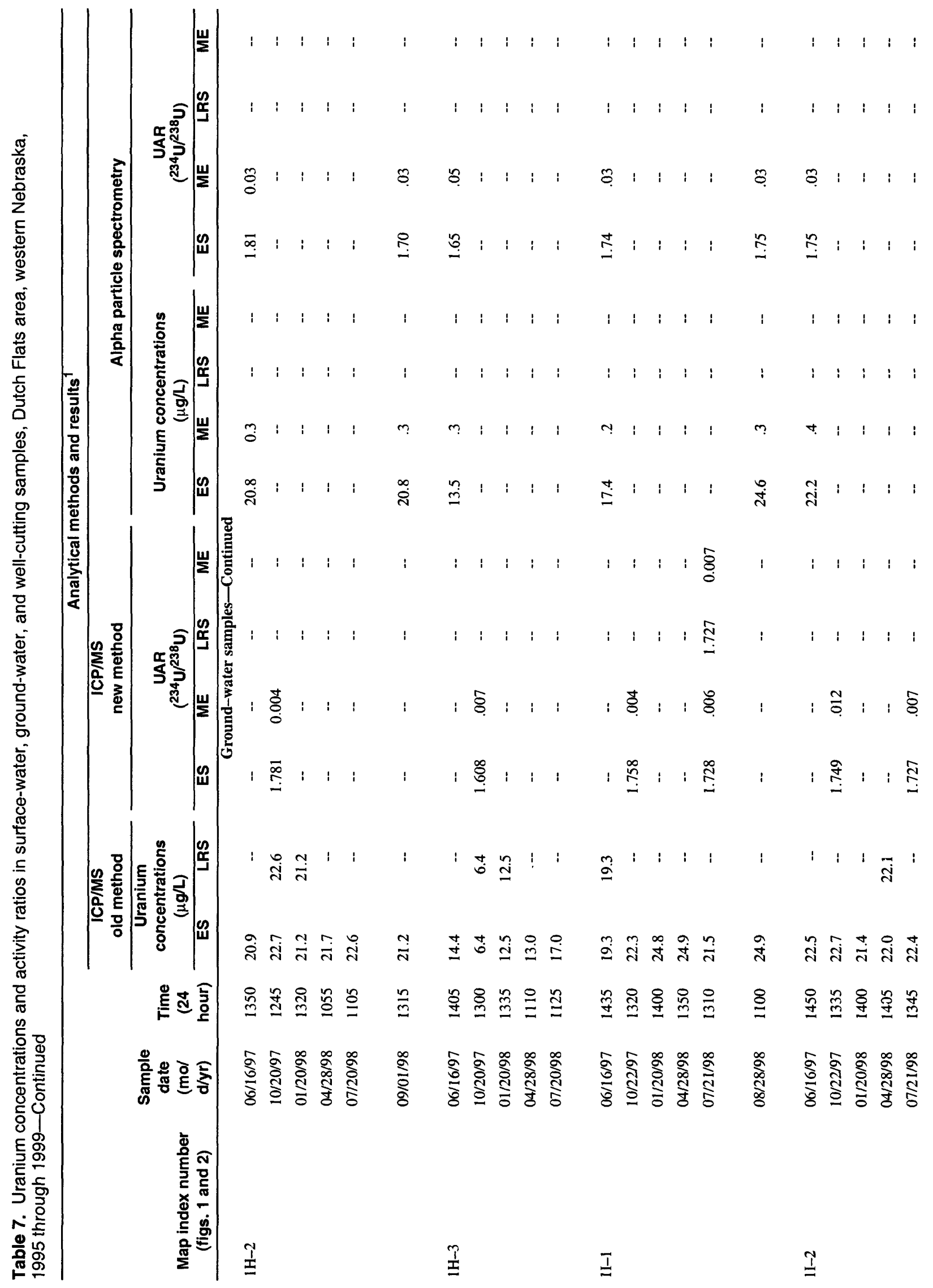




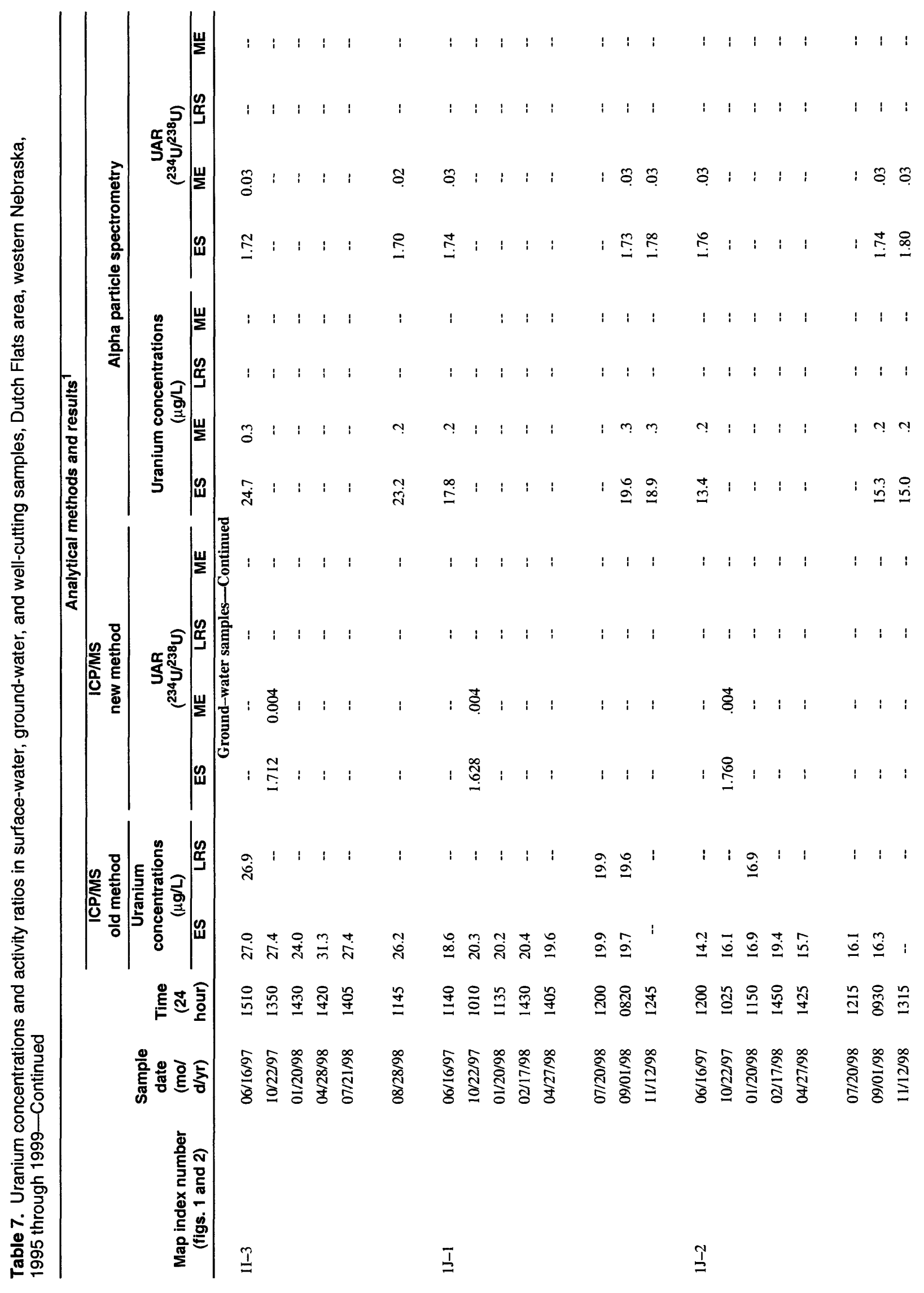




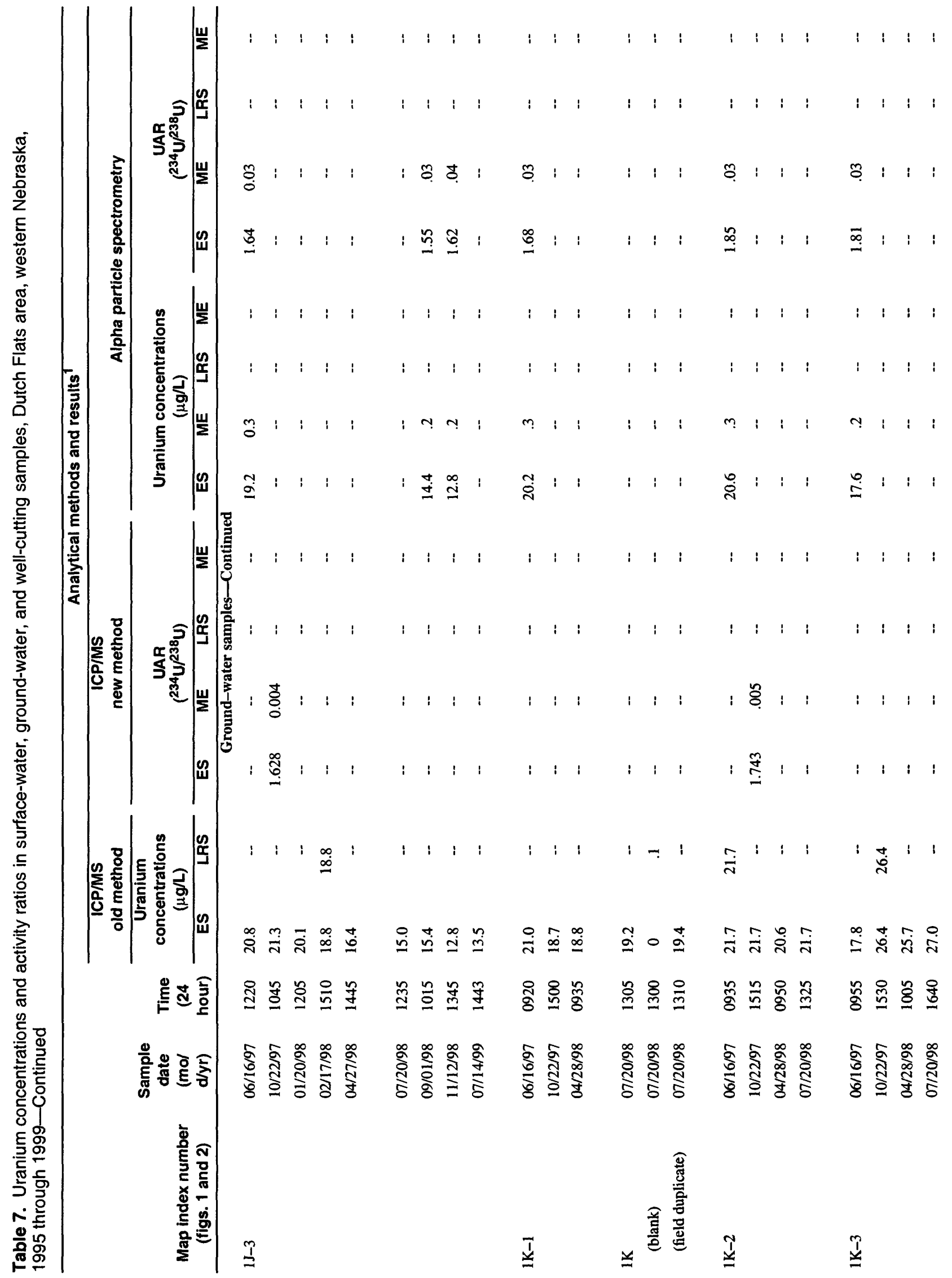

38 Selected Field and Analytical Methods and Analytical Results in the Dutch Flats Area, Western Nebraska, 1995-99 


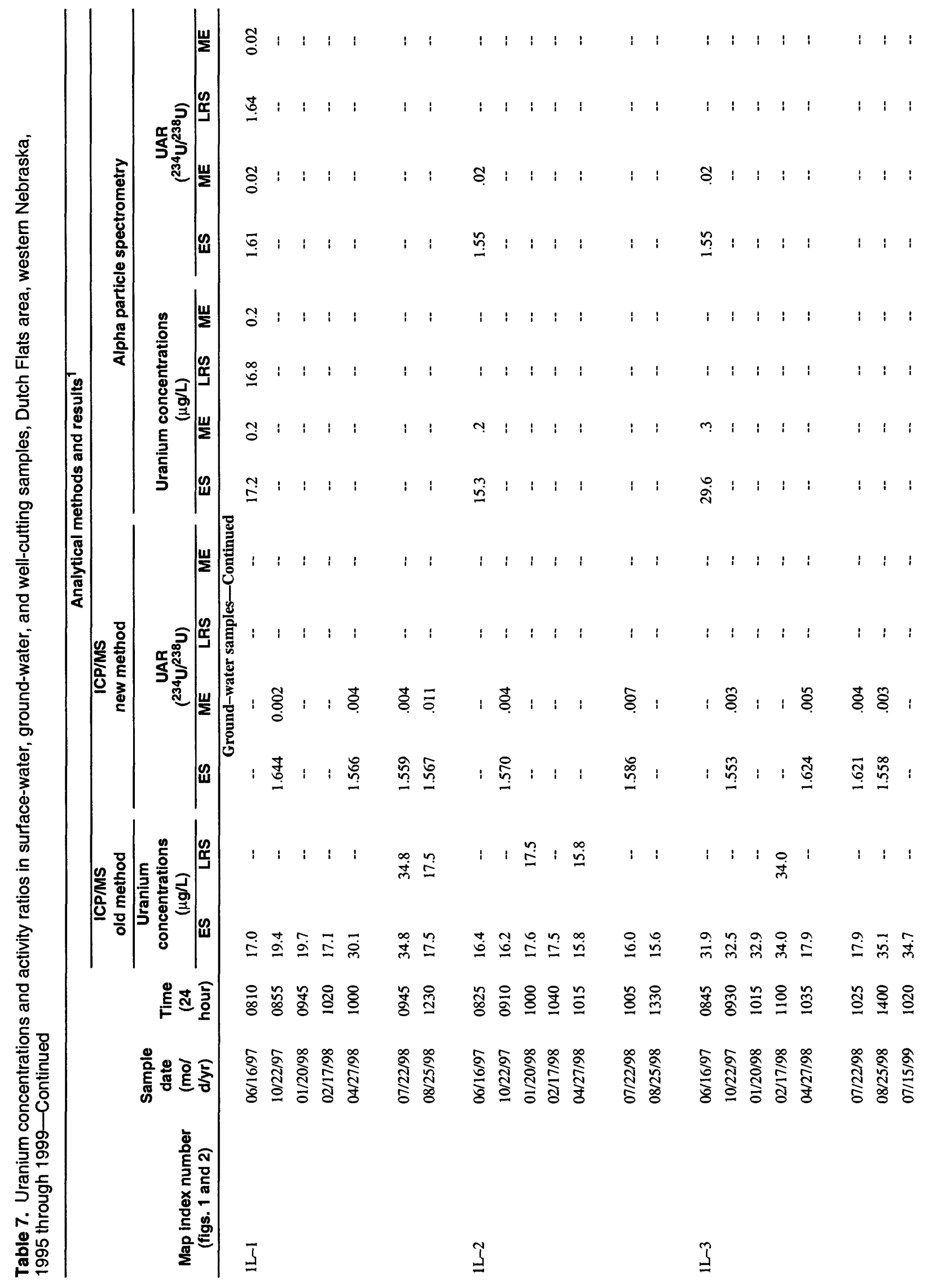




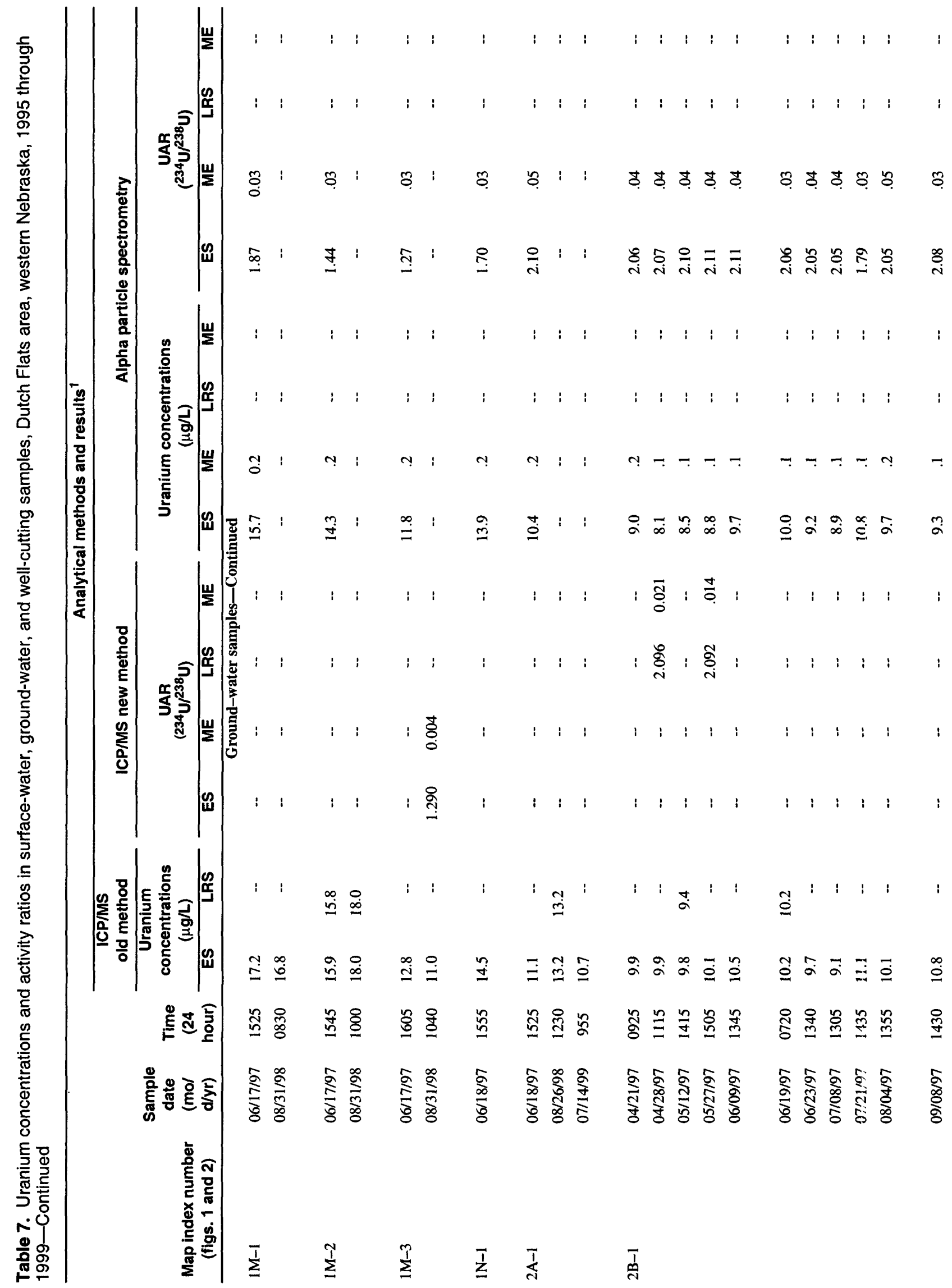




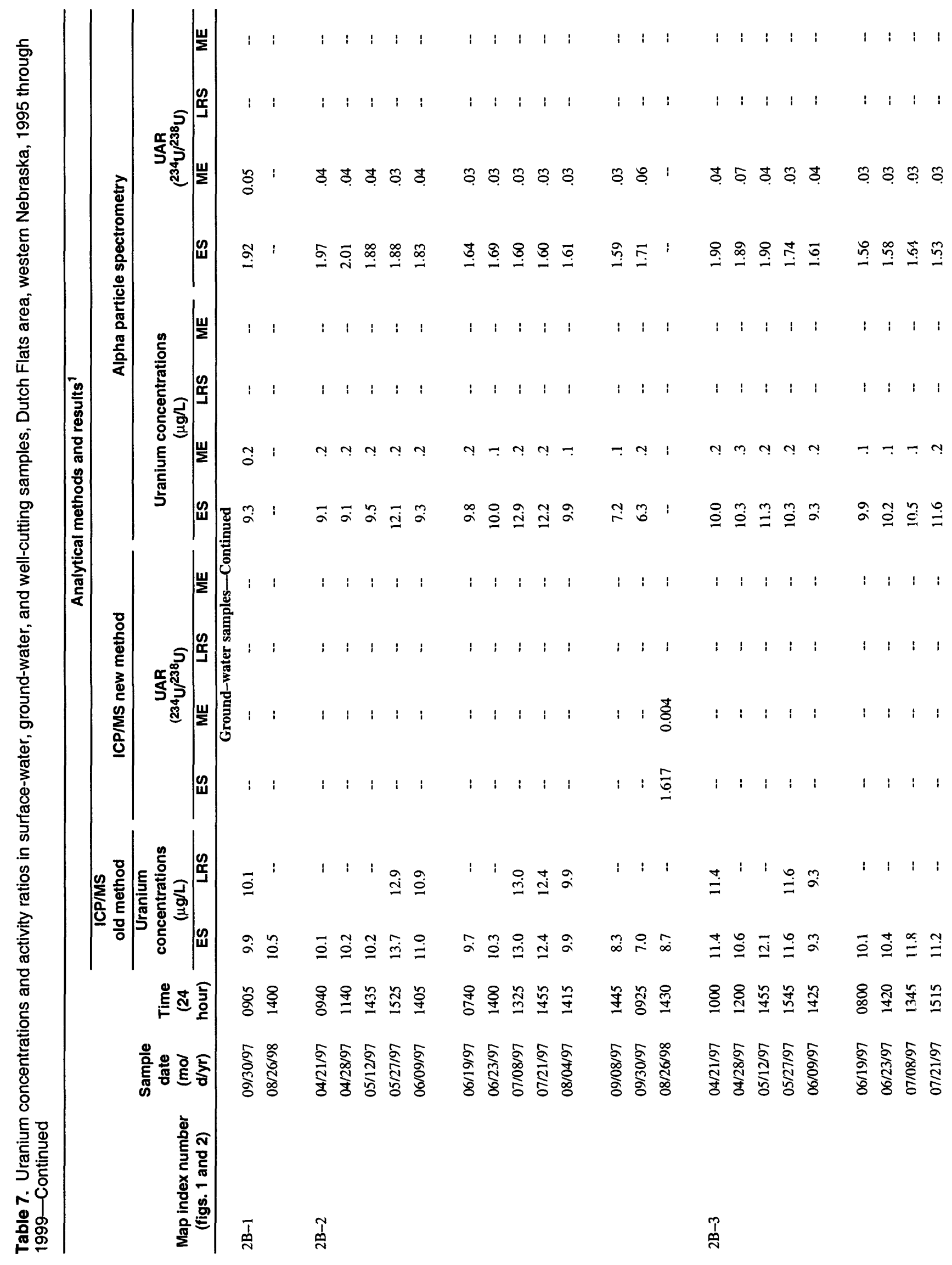




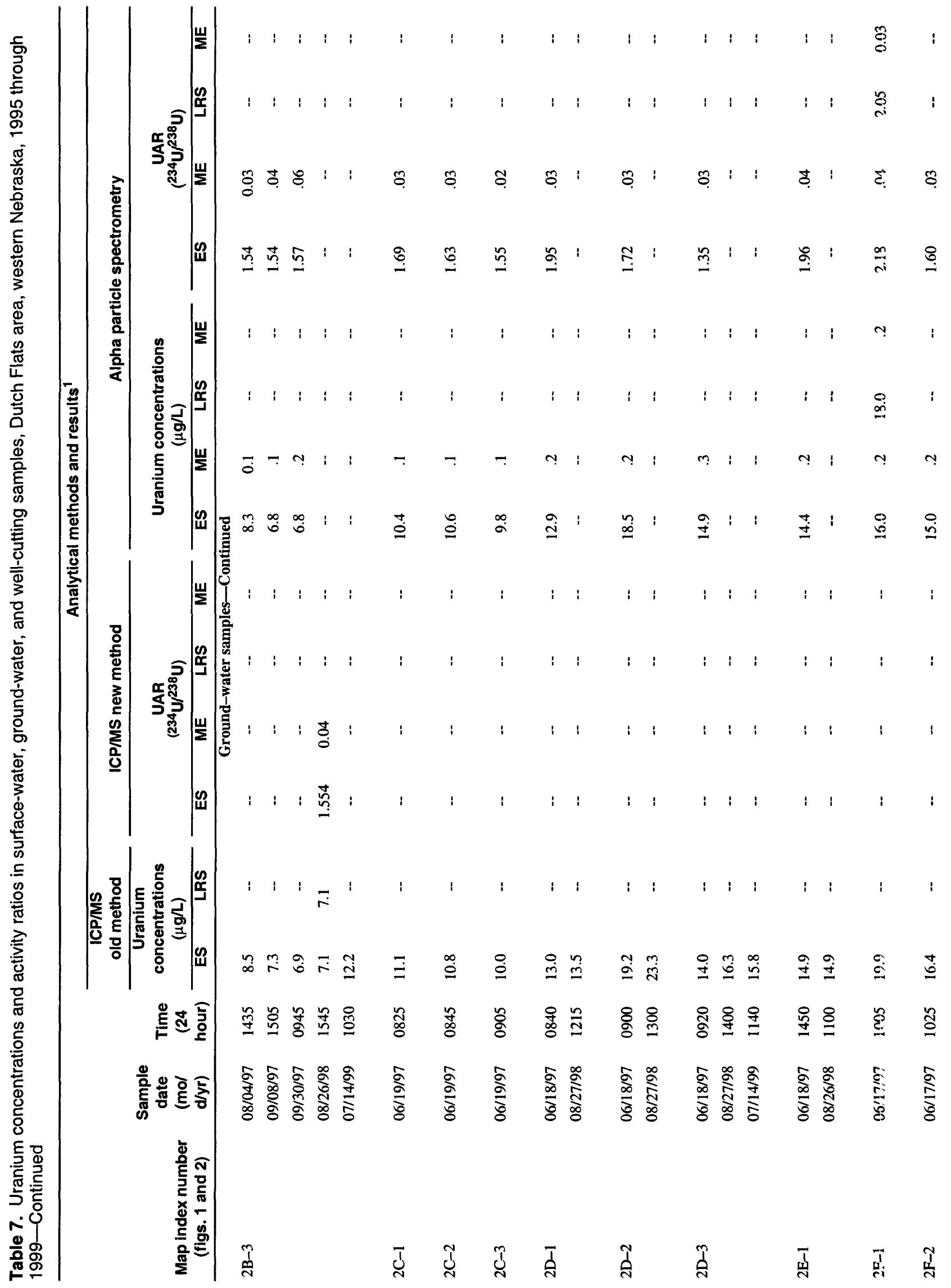




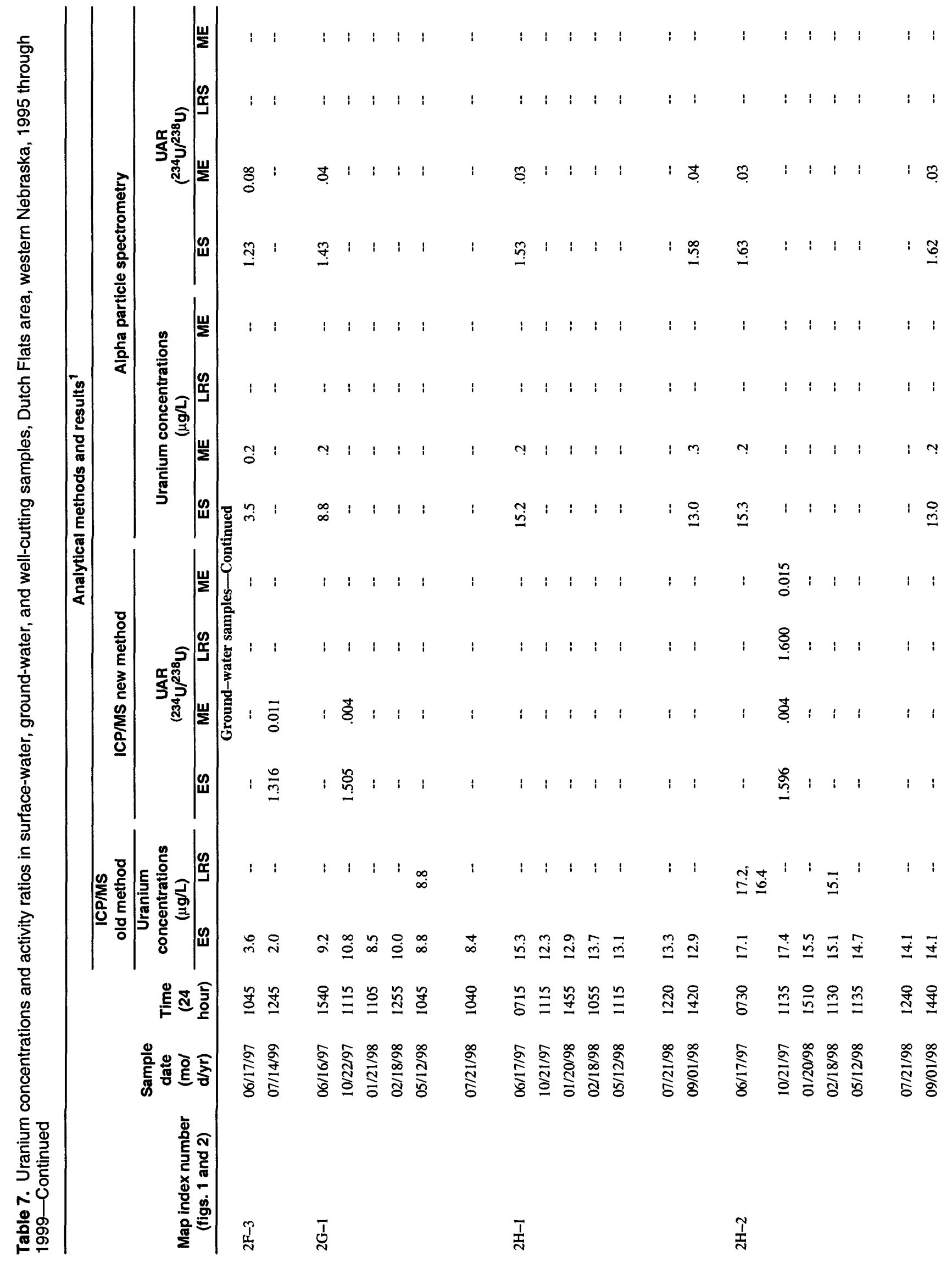




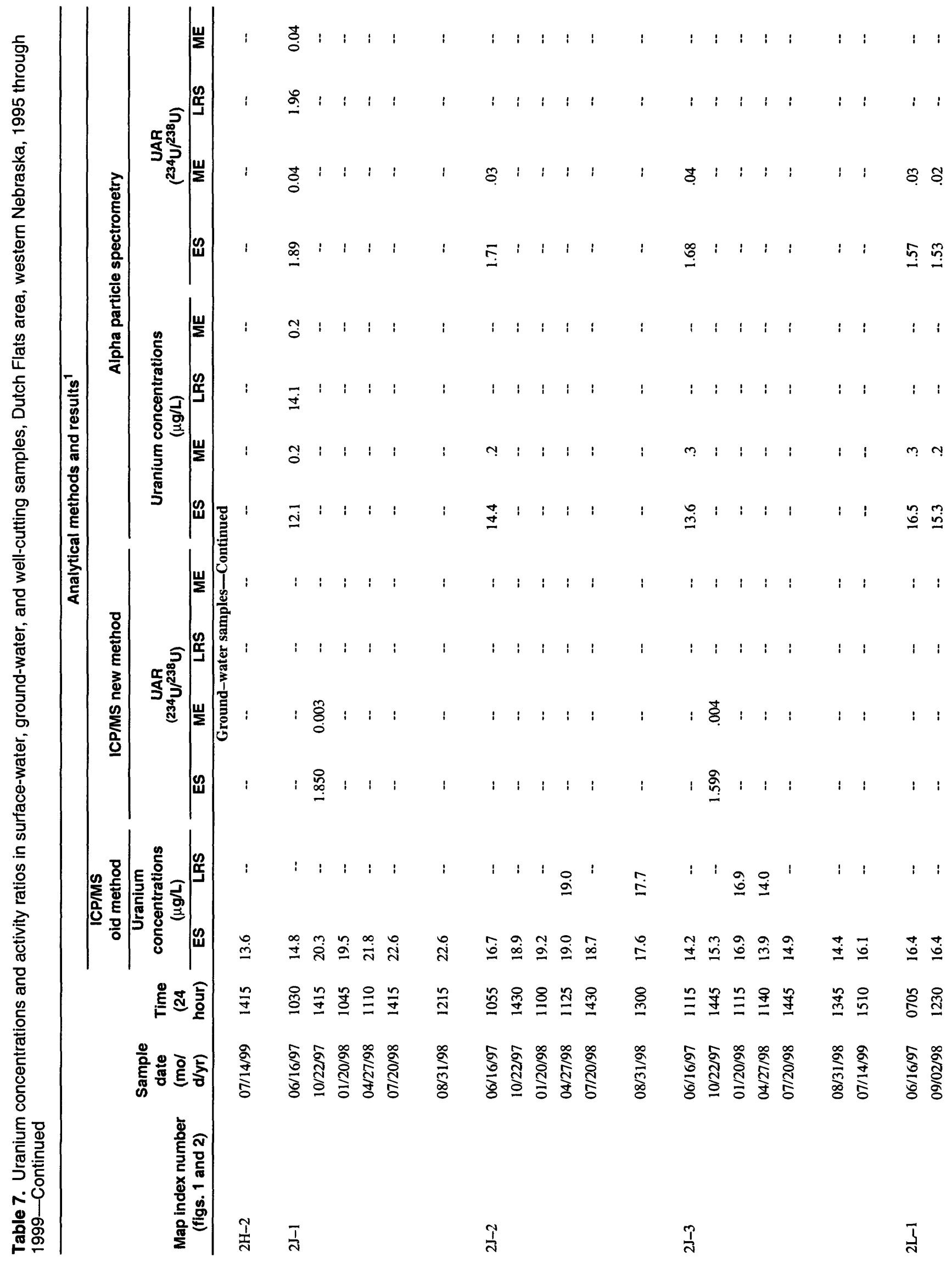

44 Selected Field and Anaiytical Methods and Analytical Results in the Dutch Flats Area, Western Nebraska, 1995-\$? 


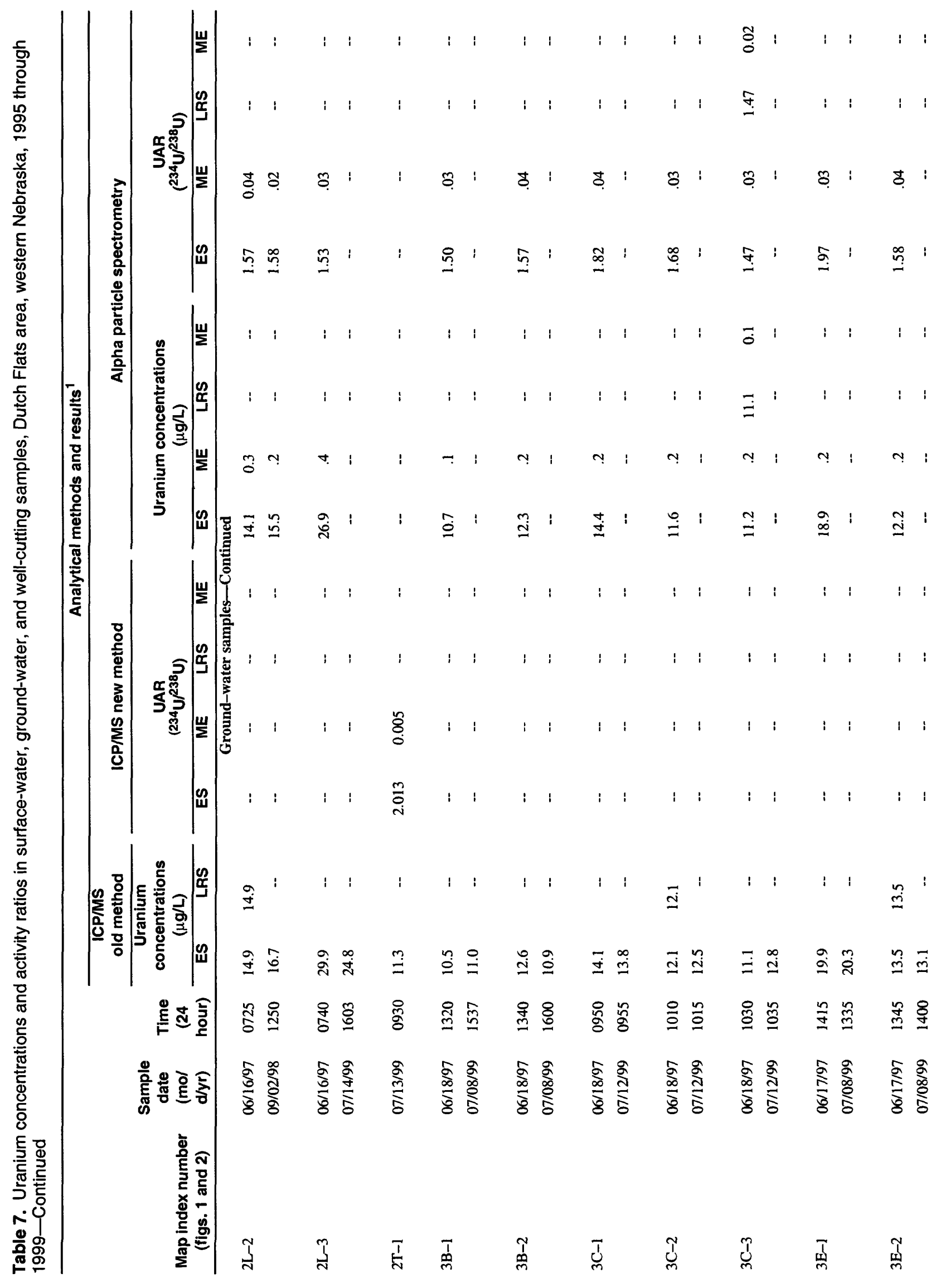




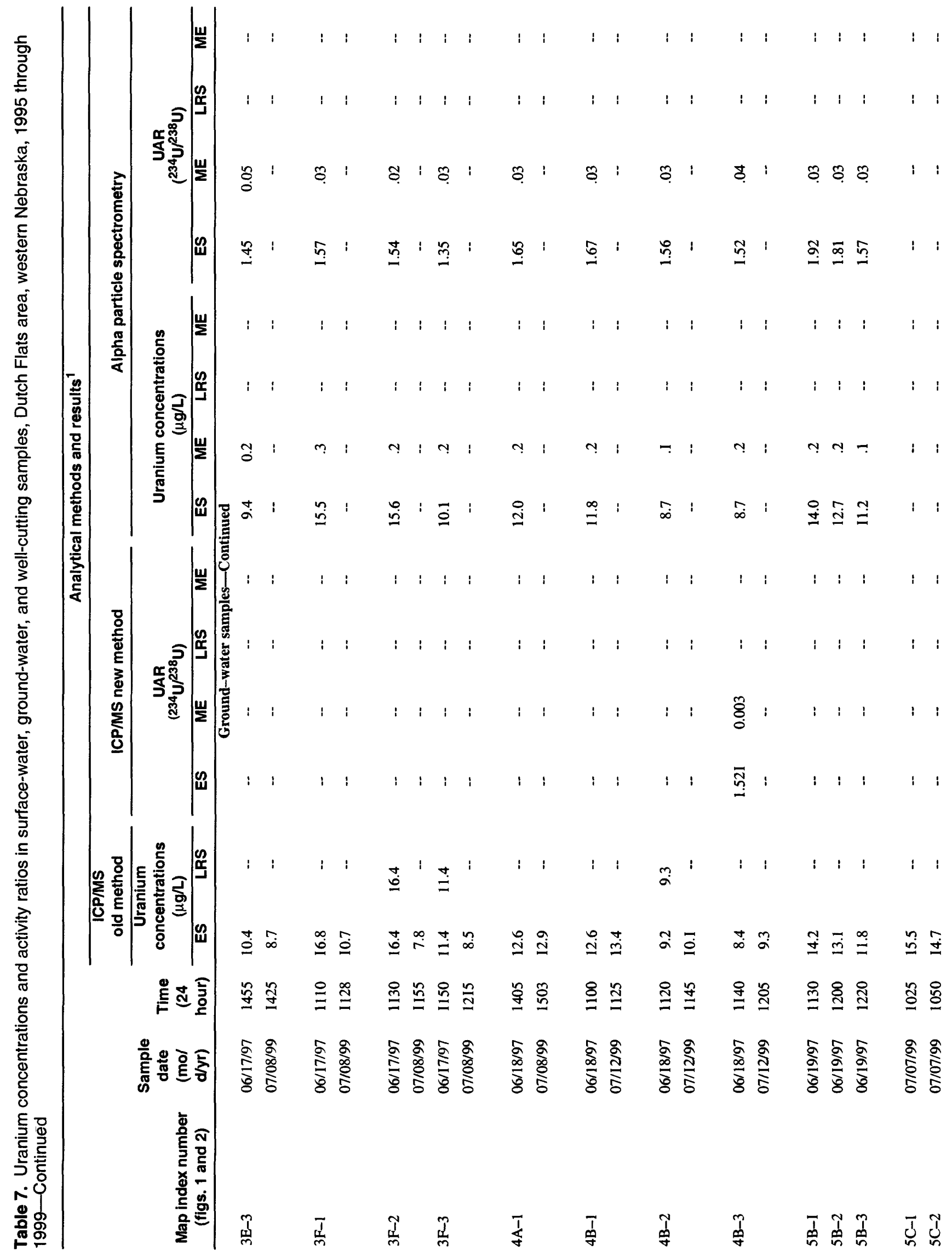

46 Selected Field and Analytical Methods and Analytical Results in the Dutch Flats Area, Western Nebraska, 1995-99 


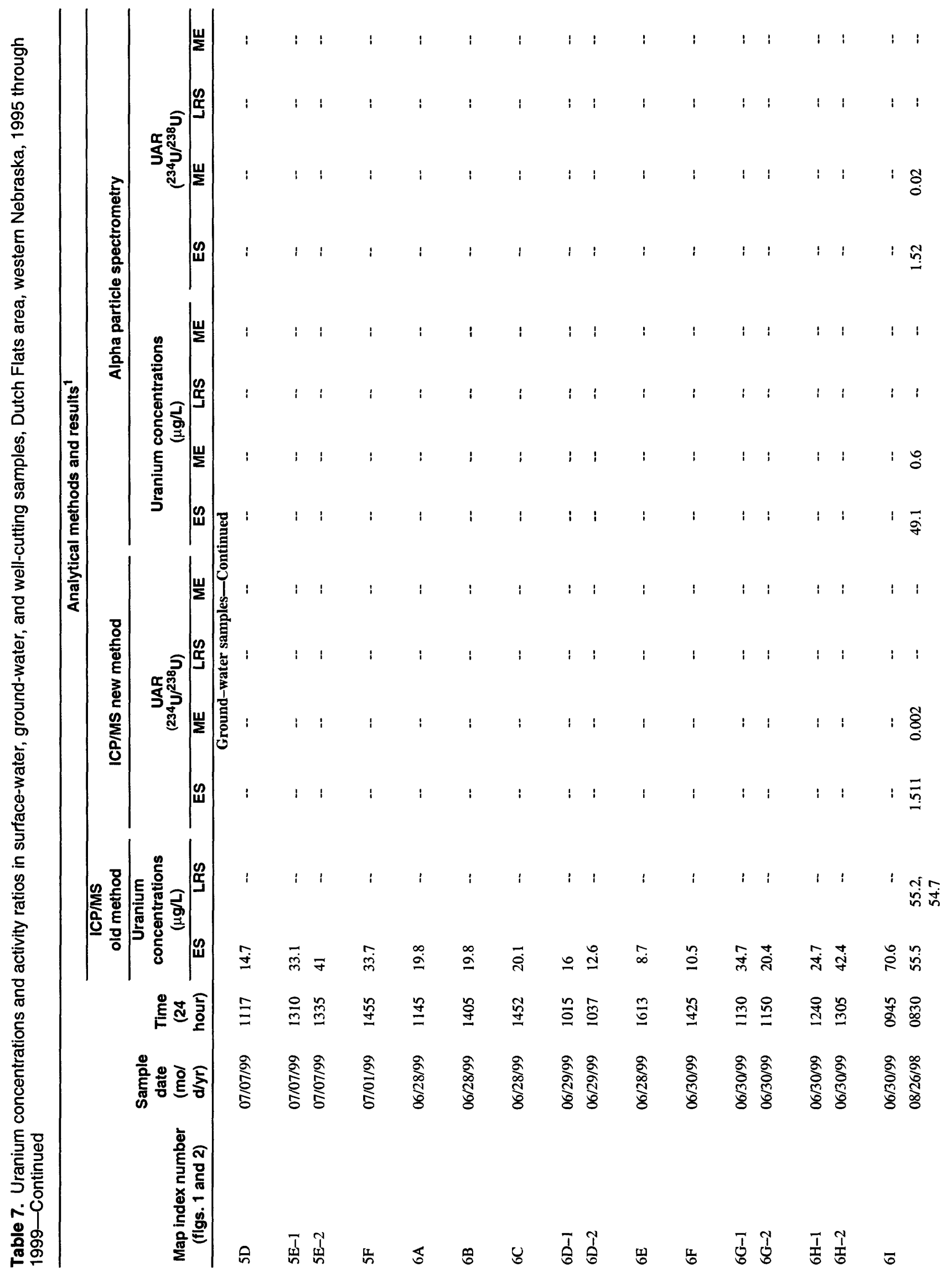




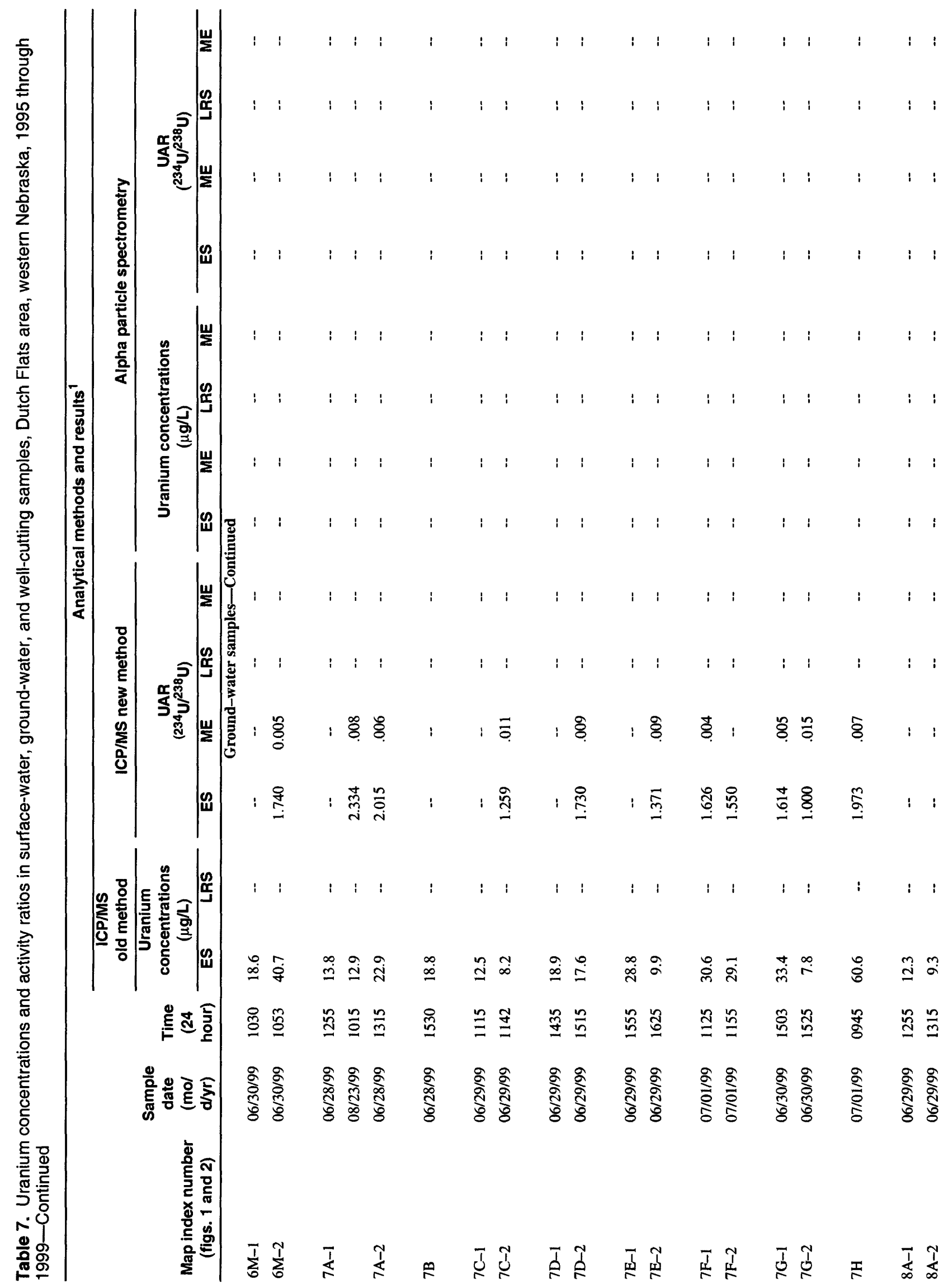




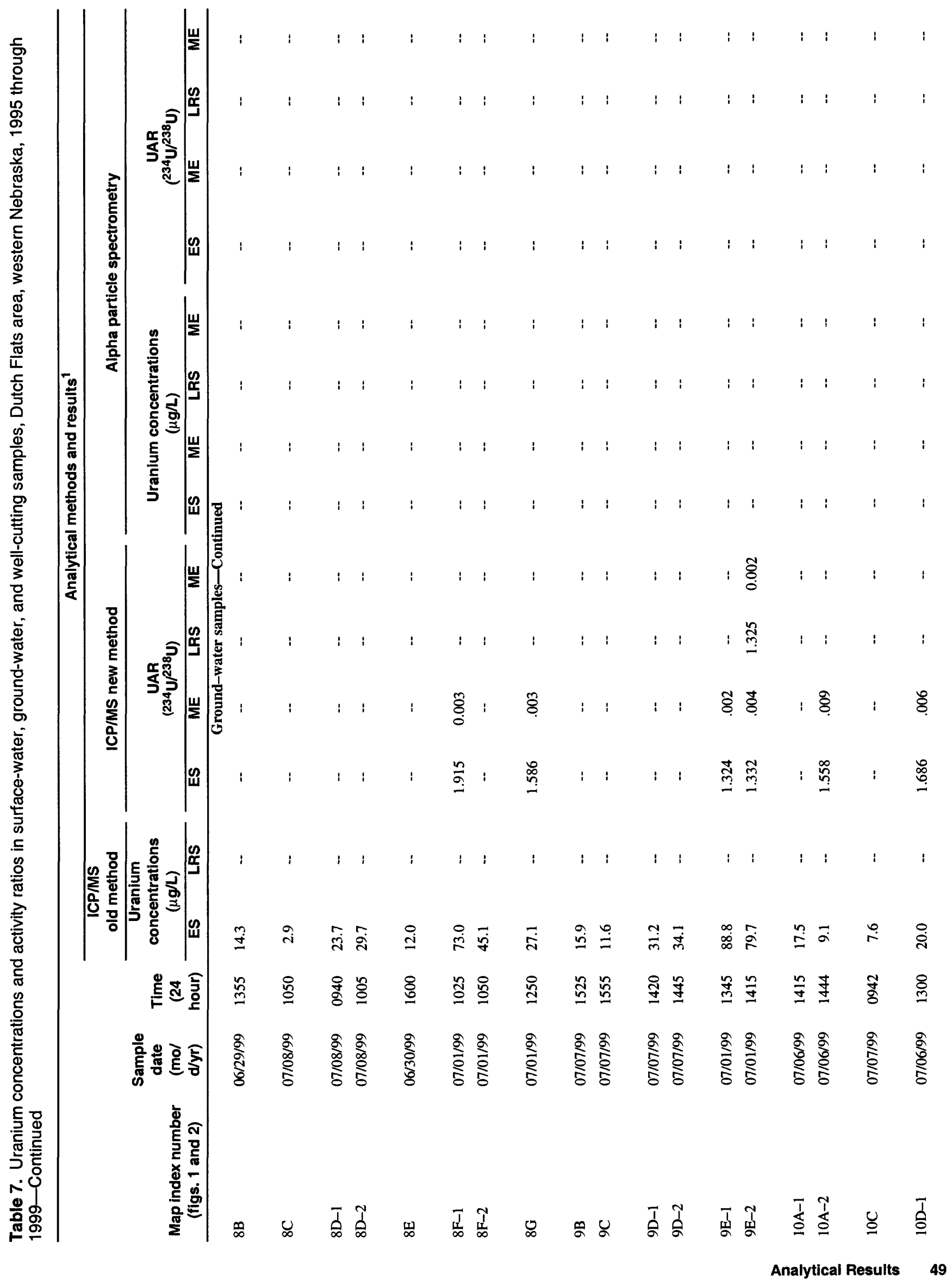




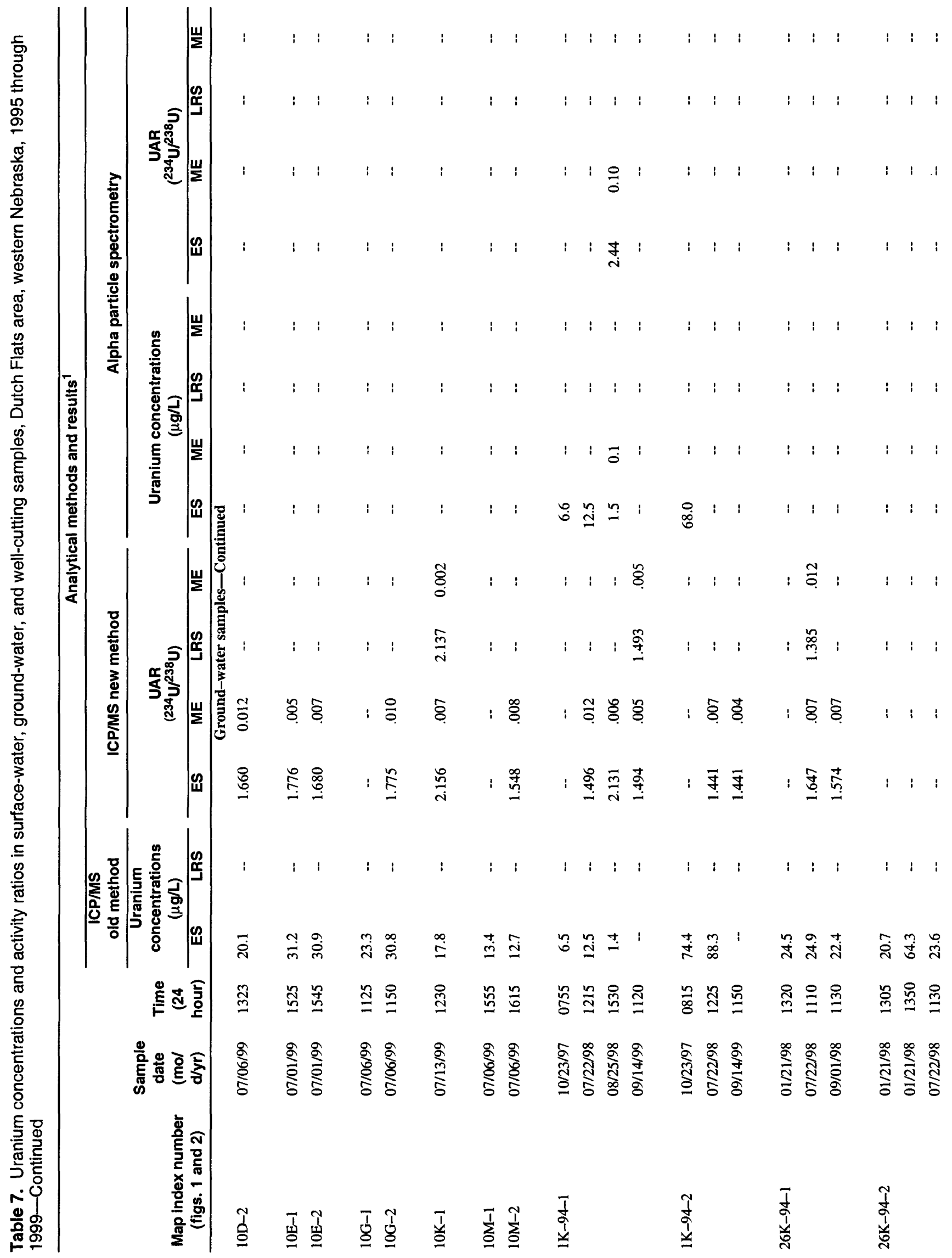




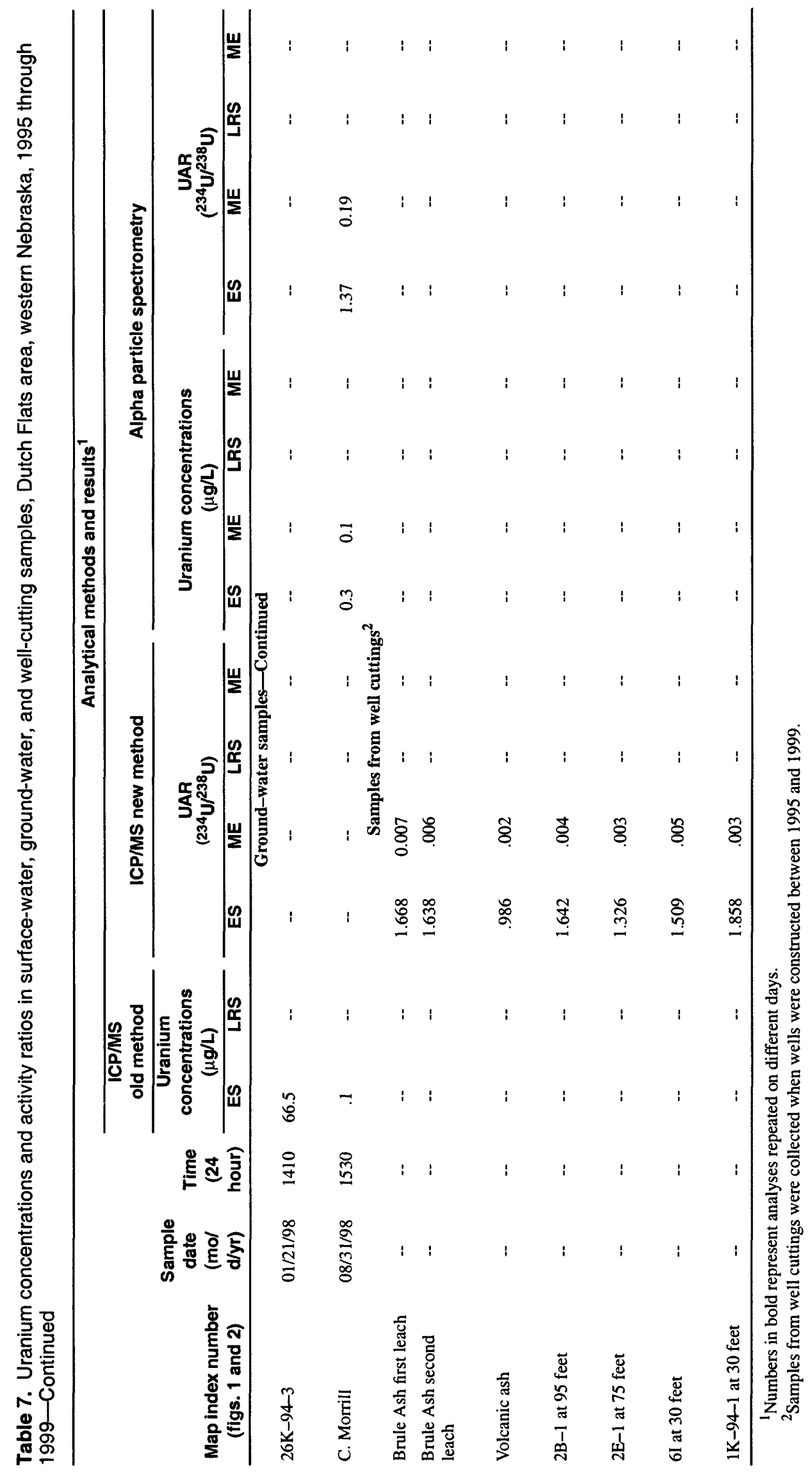




\section{REFERENCES}

Aeschbach-Hertig, W., Peeters, F., Beyerle, U., and Kipfer, R., 1999, Interpretation of dissolved atmospheric noble gases in natural waters: Water Resources Research, v. 35 , p. $2779-2792$.

Böhlke, J.K., and Coplen, T.B., 1995, Interlaboratory comparison of reference materials for nitrogen-isotoperatio measurements, in International Atomic Energy Agency, 1995, Reference and intercomparison materials for stable isotopes of light elements: International Atomic Energy Agency TECDOC 825, p. 51-66.

Böhlke, J.K., and Denver, J.M., 1995, Combined use of groundwater dating, chemical, and isotopic analyses to resolve the history and fate of nitrate contamination in two agricultural watersheds, Atlantic coastal plain, Maryland: Water Resources Research, v. 31, p. 2319-2339.

Boohar, J.A., 2000, Water resources data-Nebraskawater year 1999: U.S. Geological Survey Water-Data Report NE-99-1, 538 p.

Boohar, J.A., and Walczyk, V.C., 1997, Water resources data-Nebraska-water year 1996: U.S. Geological Survey Water-Data Report NE-96-1, 349 p. -1998, Water resources data-Nebraska-water year 1997: U.S. Geological Survey Water-Data Report NE-97-1, 462 p.

Busenberg, Eurybiades, and Plummer, L.N., 1992, Use of chlorofluorocarbons $\left(\mathrm{CCl}_{3} \mathrm{~F}\right.$ and $\left.\mathrm{CCl}_{2} \mathrm{~F}_{2}\right)$ as hydrologic tracers and age-dating tools-the alluvium and terrace system of central Oklahoma: Water Resources Research, v. 28, p. 2257-2283.

Carter, R.W., and Davidian, Jacob, 1968, Techniques of water-resources investigations of the U.S. Geological Survey, general procedures for gaging streams: U.S. Geological Survey Techniques of WaterResources Investigations Report, book 3, chap. A6, $13 \mathrm{p}$.

Conservation and Survey Division, 1980a, Ground water nitrate-as-nitrogen concentrations-Scotts Bluff quadrangle: University of Nebraska-Lincoln, 1 sheet, scale $1: 250,000$.

$1980 \mathrm{~b}$, Ground water nitrate-as-nitrogen concentrations-Alliance quadrangle: University of NebraskaLincoln, 1 sheet, scale 1:250,000.

Cook, P.G., and Böhlke, J.K., 1999, Determining timescales for groundwater flow and solute transport, in Cook, P.G., and Herczeg, A.L., eds., Environmental tracers in subsurface hydrology: Boston, Kluwer Academic Publishers, chap. 1, p. 1-30.

Coplen, T.B., 1988, Normalization of oxygen and hydrogen isotope data: Chemical Geology (Isotope Geoscience Section), v. 72, p. 293-297.

Craig, H., 1961, Isotopic variations in meteoric waters: Science, v. 133, p. 1702-1703.
Dansgaard, W., 1964, Stable isotopes in preciץ itation: Tellus, v. 16, p. 436-468.

Druliner, A.D., Esmoil, B.J., and Spears, J.M., 1999, Field screening of water quality, bottom sediment, and biota associated with irrigation drainage in the North Platte Project Area, Nebraska and Wyoming, 1995: U.S. Geological Survey Water-Resources Invertigations Report 98-4210, 43 p.

Fishman, M.J., and Friedman, L.C., 1989, Methods for determination of inorganic substances in water and fluvial sediments: U.S. Geological Surve? Techniques of Water-Resources Investigations, book 5, chap. Al, $545 \mathrm{p}$.

Gonfiantini, R., 1986, Environmental isotopes in lake studies, in Fritz, P., and Fontes, J.Ch., eds., Handbook of environmental isotope geochemistry, volume 2Bthe terrestrial environment: New York, E'sevier, p. 113-168.

International Atomic Energy Agency, 1981, S able isotope hydrology-deuterium and oxygen-18 in the water cycle: Technical Report Series No. 210, 337 p. 1992, Statistical treatment of data on environmental isotopes in precipitation: Technical Report Series No. 331, 781 p.

Ivanovich, M., and Murray, A., 1992, Spectroscopic methods, in Ivanovich, M., and Harmon, R.S., eds., Uranium-series disequilibrium-applications to earth, marine, and environmental sciences, second edition: Oxford, Clarendon Press, p. 127-173.

Ludin, A., Weppernig, R., Bönisch, G., and Schlosser, P., 1998, Mass spectrometric measurement of helium isotopes and tritium. Lamont-Doherty Technical Report 98-06, [http://www.ldeo.columbia.edu/ noblegas/ms_ms/Ludin_et_al_MS_Pap?r.html]

Mamyrin, B.A., and Tolstikhin, I.N., 1984, Helium isotopes in nature: New York, Elsevier, 273 p.

Mathey, S.B., ed., 1990, Ground-water site in rentory system, v. 2, chap. 4, in National Water Information System user's manual: U.S. Geological Survey OpenFile Report 89-587, 288 p.

Plummer, L.N., and Busenberg, Eurybiades, 1999, Chlorofluorocarbons, in Cook, P.G., and Herczeg, A.L., eds., Environmental tracers in subsurface hyd ology: Boston, Kluwer Academic Publishers, chap. 15, p. 441-478.

Plummer, L.N., Rupert, M.G., Busenberg, Eu-ybiades, and Schlosser, P., 1999, Age of irrigation wa+er in ground water from the eastern Snake River Plair aquifer, south-central Idaho: Ground Water, v. 3\&, p. 264-283.

Pritt, J.W., and Jones, B.E., eds., 1990, National waterquality services catalog: U.S. Geological Survey OpenFile Report 89-386, 132 p.

Rantz, S.E., 1982, Measurement and computation of streamflow, volume 1 -measurement of stage and 
discharge: U.S. Geological Survey Water-Supply Paper 2175, p. 284.

Schlosser, P., Shapiro, S.D., Stute, M., Aeschbach-Hertig, W., Plummer, L.N., and Busenberg, Eurybiades, 1998, Tritium $/{ }^{3} \mathrm{He}$ measurements in young ground water-chronologies for environmental records, in Isotope techniques in the study of environmental change: International Atomic Energy Agency, Proceedings Series, Vienna, p. 165-189.

Steele, G.V., and Cannia, J.C., 1997, Reconnaissance of surface-water quality in the North Platte Natural Resources District, western Nebraska, 1993: U.S. Geological Survey Water-Resources Investigations Report 96-4316, 21 p.

Stute, M., and Schlosser, P., 1999, Atmospheric noble gases, in Cook, P.G., and Herczeg, A.L., eds., Environmental tracers in subsurface hydrology: Boston, Kluwer Academic Publishers, p. 348-377.

Thatcher, L.L., Janzen, V.J., and Edwards, K.W., 1977, Methods for determination of radioactive substances in water in fluvial sediments: U.S. Geological Survey Techniques of Water-Resources Investigations, book 5 , chap. A5, p. 93-95.

U.S. Environmental Protection Agency, 1994, Methods for the determination of metals in environmental samples: Washington, D.C., EPA 600/R-94-111, Supplement 1.

2000 , Current drinking water standards-national primary and secondary drinking water regulations: Office of Ground Water and Drinking Water, accessed December 27, 2000, at URL http://www.epa.gov/ safewater/standards.html

Verstraeten, I.M., Carr, J.D., Steele, G.V., Thurman, E.M., Meyer, M.T., and Dormedy, D.F., 1999, Surface- water/ground-water interaction-herbicide transport into municipal collector wells: Journal of Environmental Quality, v. 28, no. 5, p. 1396-1405.

Verstraeten, I.M., Sibray, S.S., Cannia, J.C., and Tanner, D.Q., 1995, Reconnaissance of ground-water quality in the North Platte Natural Resources District, weste $n$ Nebraska, June-July 1991: U.S. Geological Surve.' Water-Resources Investigations Report 94-4057, $114 \mathrm{p}$.

Verstraeten, I.M., Steele, G.V., Cannia, J.C., Hitch, D.E., Scriptner, K., Böhlke, J.K., Kraemer, T.F., and Star'on, J.S., 2001, Interaction of surface water and ground water in the Dutch Flats area, western Nebraska, 1995-99: U. S. Geological Survey Water-Resources Investigations Report 01-4070, $56 \mathrm{p}$.

Vogel, J.C., 1967, Investigation of groundwater flow with radiocarbon, in International Atomic Energy Agercy, Isotopes in hydrology: Vienna, International Atoric Energy Agency, p. 355-369.

Weiss, R.F., 1970, The solubility of nitrogen, oxygen, and argon in water and seawater: Deep-Sea Research, v. 17, p. 721-735.

1971, Solubility of helium and neon in water ard seawater: Journal of Chemical Engineering Data, v. 16, p. 235-241.

Wells, F.C., Gibbons, W.J., and Dorsey, M.E., 1990, Guidelines for collected and field analysis of water-qualty samples from streams in Texas: U.S. Geological Survey Open-File Report 90-127, 79 p.

Whittaker, E.L., Akridge, J.D., and Giovino, J., 1989, Two test procedures for radon in drinking water: U.S. Environmental Protection Agency, EPA/600/2-87/082, p. 2-10. 